UNIVERSIDAD NACIONAL DE LA PLATA

Facultad de Ciencias Jurídicas y Sociales

Secretaría de Postgrado

\title{
ADHESIÓN DE LA REPÚBLICA AUTÓNOMA DE CRIMEA SUBSUMIDA EN EL CONFLICTO RUSO UCRANIANO
}

Tesis para obtener el grado académico de Magíster en Inteligencia Estratégica Nacional

Licenciado TATO GIUSTINA

Director: Doctor Luis Alberto Gabriel Somoza

Ciudad Autónoma de Buenos Aires

República Argentina, 2016 
"... la inteligencia es una cosa simple y que se evidencia por sí misma. Como actividad, es la prosecución de cierta clase de conocimiento; como fenómeno, es el conocimiento resultante. En reducida escala, es lo que todos nosotros hacemos cada día."

Sherman Kent

Mi agradecimiento al Doctor Luis Alberto Gabriel Somoza por su guía y compromiso académico.

Lic. Tato Giustina 
TABLA DE CONTENIDO

Página

\section{INTRODUCCIÓN}

\section{CAPÍTULO I}

1. Síntesis histórica de Crimea

2. La importancia de Crimea para Rusia

3. Otras causas y consecuencias del vigente conflicto

4. Unión de Repúblicas Socialistas Soviéticas a la Rusia actual

\section{CAPÍTULO ॥}

1. Objetivo general

2. Objetivos específicos

3. Alcances

\section{CAPÍTULO III}

MARCO TEÓRICO METODOLÓGICO

1. El realismo y las relaciones mundiales $\quad 7$

2. Nuevo orden mundial $\quad 8$

3. El conflicto ruso ucraniano bajo una perspectiva realista sistémica estructural 10

4. Adhesión de la República Autónoma de Crimea (dialéctica de voluntades) 10

5. Inteligencia estratégica 11

5.1. Situación estratégica 11

5.1.1. La Federación de Rusia como protagonista y la emergencia de su misión 11

5.1.2. Federación de Rusia: misión 15

5.1.3. Actores $\quad 15$

(i) Federación de Rusia (protagonista) $\quad 15$

(ii) Ucrania 16

(iii) Estados Unidos de América 16

(iv) Reino Unido de Gran Bretaña e Irlanda del Norte 17

(v) República de Polonia $\quad 19$

(vi) República de Turquía $r$

(vii) República Federal de Alemania $\quad 20$

(viii) República Francesa $\quad 21$

(ix) República Islámica de Irán $\quad 22$

(x) República Popular de China $\quad 24$

5.1.4. Psicología de los actores 25

(i) Racionalidad: intereses de los actores $\quad 25$

Planillas de identificación de intereses de los actores $\quad 26$

(ii) Motivación de los actores

5.1.5. Trama del conflicto

5.1.6. Sociogramas de identificación, poder y fuerzas 78

5.1.7. Escenario $\quad 82$

(i) Espacios $\quad 82$ 
Página

(a) Foros $\quad 82$

(b) Mercados

(c) Territorios

(ii) Reglas de juego $\quad 84$

Sanciones $\quad 86$

5.2. Evolución de la situación estratégica 86

5.2.1. Coaliciones (equilibrio de la identificación)

5.2.2. Equilibrio de poder $\quad 87$

5.3. Evaluación de la situación estratégica 88

CAPÍTULO IV

$\begin{array}{lr}\text { CONCLUSIONES } & 90\end{array}$

BIBLIOGRAFÍA

Documentos, informes, notas y mapas $\quad 96$ 


\section{ÍNDICE DE PLANILLAS, CUADROS, SOCIOGRAMAS Y MAPAS}

Página

Planilla 01. Intereses RU (protagonista)

Planilla 02. Intereses UA $\quad 27$

Planilla 03. Intereses US $\quad 28$

Planilla 04. Intereses GB $\quad 28$

Planilla 05. Intereses PL $\quad 29$

Planilla 06. Intereses TR $\quad 29$

Planilla 07. Intereses DE $\quad 30$

Planilla 08. Intereses FR $\quad 30$

Planilla 09. Intereses IR

Planilla 10. Intereses CN 31

Cuadro I. Motivación de los actores

Planilla 11. Relaciones de intereses Federación de Rusia - Ucrania 33

Planilla 12. Relaciones de intereses Federación de Rusia - Estados Unidos de América 34

Planilla 13. Relaciones de intereses Federación de Rusia - Reino Unido de Gran Bretaña e Irlanda del Norte 35

Planilla 14. Relaciones de intereses Federación de Rusia - República de Polonia 36

Planilla 15. Relaciones de intereses Federación de Rusia - República de Turquía 37

Planilla 16. Relaciones de intereses Federación de Rusia - República Federal de Alemania 38

Planilla 17. Relaciones de intereses Federación de Rusia - República Francesa 39

Planilla 18. Relaciones de intereses Federación de Rusia - República Islámica de Irán 40

Planilla 19. Relaciones de intereses Federación de Rusia - República Popular de China 41

Planilla 20. Relaciones de intereses Ucrania - Estados Unidos de América 42

Planilla 21. Relaciones de intereses Ucrania - Reino Unido de Gran Bretaña e Irlanda del Norte 43

Planilla 22. Relaciones de intereses Ucrania - República de Polonia 44

Planilla 23. Relaciones de intereses Ucrania - República de Turquía 45

Planilla 24. Relaciones de intereses Ucrania - República Federal de Alemania 46

Planilla 25. Relaciones de intereses Ucrania - República Francesa 47

Planilla 26. Relaciones de intereses Ucrania - República Islámica de Irán 48

Planilla 27. Relaciones de intereses Ucrania - República Popular de China 49

Planilla 28. Relaciones de intereses Estados Unidos de América - R. U. de G. Bretaña e Irlanda del Norte 50

Planilla 29. Relaciones de intereses Estados Unidos de América - República de Polonia 51

Planilla 30. Relaciones de intereses Estados Unidos de América - República de Turquía 52

Planilla 31. Relaciones de intereses Estados Unidos de América - República Federal de Alemania 53

Planilla 32. Relaciones de intereses Estados Unidos de América - República Francesa 54

Planilla 33. Relaciones de intereses Estados Unidos de América - República Islámica de Irán 55

Planilla 34. Relaciones de intereses Estados Unidos de América - República Popular de China 56

Planilla 35. Relaciones de intereses R. U. de G. Bretaña e Irlanda del Norte - República de Polonia $\quad 57$

Planilla 36. Relaciones de intereses R. U. de G. Bretaña e Irlanda del Norte - República de Turquía 58

Planilla 37. Relaciones de intereses R. U. de G. Bretaña e Irlanda del Norte - República Federal de Alemania 59

Planilla 38. Relaciones de intereses R. U. de G. Bretaña e Irlanda del Norte - República Francesa 60

Planilla 39. Relaciones de intereses R. U. de G. Bretaña e Irlanda del Norte - República Islámica de Irán 61

Planilla 40. Relaciones de Intereses R. U. de G. Bretaña e Irlanda del Norte - República Popular de China 62

Planilla 41. Relaciones de intereses República de Polonia - República de Turquía 63

Planilla 42. Relaciones de intereses República de Polonia - República Federal de Alemania 64

Planilla 43. Relaciones de intereses República de Polonia - República Francesa 65

Planilla 44. Relaciones de intereses República de Polonia - República Islámica de Irán 66

Planilla 45. Relaciones de intereses República de Polonia - República Popular de China 67 
Planilla 46. Relaciones de intereses República de Turquía - República Federal de Alemania 68

Planilla 47. Relaciones de intereses República de Turquía - República Francesa 69

Planilla 48. Relaciones de intereses República de Turquía - República Islámica de Irán 70

Planilla 49. Relaciones de intereses República de Turquía - República Popular de China 71

Planilla 50. Relaciones de intereses República Federal de Alemania - República Francesa 72

Planilla 51. Relaciones de intereses República Federal de Alemania - República Islámica de Irán 73

Planilla 52. Relaciones de intereses República Federal de Alemania - República Popular de China 74

Planilla 53. Relaciones de intereses República Francesa - República Islámica de Irán 75

Planilla 54. Relaciones de intereses República Francesa - República Popular de China 76

Planilla 55. Relaciones de intereses República Islámica de Irán - República Popular de China 77

Notación para Sociogramas $\quad 78$

Identificación $\quad 79$

Poder $\quad 80$

Cuadro de identificación y poder $\quad 81$

Cuadro II. Relación de identificación entre actores $\quad 81$

Cuadro III. Relación de poder entre actores

Coaliciones (equilibrio de la identificación) $\quad 87$

Cuadro IV. Matriz de poder $\quad 88$

Cuadro V. Evaluación de la situación estratégica $\quad 89$

Mapa I. Península de Crimea $\quad 97$

Mapa II. Gasoductos rusos orientados a la Unión europea 98 


\section{INTRODUCCIÓN}

Trabajo de investigación exploratorio descriptivo, cuyo objeto de estudio el proceso de adhesión de la península de Crimea a territorio ruso, se abordará bajo el marco teórico metodológico dado por el Doctor Federico Frischknecht y otros en lógica, teoría y práctica de la estrategia1. Teniendo como objetivo, describir -dentro del tiempo establecido- si existe relación entre la misión del protagonista y dicha integración. Para ello, será necesario confirmar -como hipótesis de trabajo- si entre el 21 de noviembre de 20132 y el 21 de marzo de 2014 inclusive, subsumida en el conflicto ruso ucraniano, el cumplimiento de la misión de la Federación de Rusia se asocia a la adhesión territorial de la República Autónoma de Crimea. Cuestión, donde serán apreciados intereses, actores, trama y escenario, atento a que Rusia -como protagonista- mantuvo la comunicación mediante cierto discurso orientado a la UE ${ }^{3}$ y OTAN $^{4}$ y, en particular a Ucrania, afirmando con hechos el mensaje de Vladimir Putin 5 de que Georgia y Ucrania son los límites a dichas organizaciones.

\footnotetext{
${ }^{1}$ ALONSO, Rodolfo J.; FRISCHKNECHT, Federico; HERNÁNDEZ OTAÑO, Felipe; LANZARINI, Mario S. T.; MOYA LATRUBESSE, Eulogio A. 1995. Lógica, teoría y práctica de la estrategia. Escuela de Guerra Naval, Área Estrategia, Buenos Aires, Argentina, pp. 271.

2 Víktor Yanukovich -21 de noviembre de 2013- decisión contra la UE. Presidente electo democráticamente en 2010, cambió la constitución en pos de más poderes. Líder del Partido de las Regiones con otrora mayoría parlamentaria. Estimó su caída como un golpe de Estado y abandonó Kiev -hacia Rusia- por temor a represalias.

3 Unión Europea. Notación abreviada UE.

${ }^{4}$ Organización del Tratado del Atlántico Norte. Notación abreviada OTAN.

5 Vladimir Vladímirovich Putin. Presidente de la Federación de Rusia con mandatos 2000/04, 2004/08 y, 2012 a la fecha.
} 


\section{CAPÍTULO I}

\section{MARCO HISTÓRICO}

\section{Síntesis histórica sobre Crimea}

La Rusia ${ }^{6}$ zarista tuvo conflictos con el Imperio Turco Otomano en los mares de Azov, Negro y Mármara, los estrechos de Kerch, Bósforo y Dardanelos, el Mar Egeo y los Balcanes, que terminaron en el Congreso de Berlín de 18787 . Durante la Primera Guerra Mundial ${ }^{8}$, Crimea ${ }^{9}$ fue el escenario de las acciones navales rusas contra Alemania ${ }^{10}$ y el Imperio Turco Otomano, con operaciones alemanas sobre Odessa, Sebastopol, Feodosia, Kerch y Novorossisk y, con actividades rusas -en apoyo de su ejército- sobre el tráfico marítimo y las posiciones costeras enemigas. Luego, durante la Segunda Guerra Mundial11 ${ }^{11}$. Alemania atacó a la URSS ${ }^{12}$ por el petróleo del Cáucaso, invadiendo Crimea y sitiando Sebastopol, para ser -a posteriori- expulsados de dicha región.

Después de la guerra, la península -cedida por Nikita Kruschev ${ }^{13}$ en 1954- pasó a dominio ucraniano, que con la caída del bloque soviético y una Ucrania ${ }^{14}$ independiente, provocó fuertes tensiones ante el separatismo proruso. Además, la división de la flota del Mar Negro en 1995 y el alquiler de su base a Rusia en 1997, conformaron hechos congruentes con el histórico proyecto zarista de inalterables objetivos, perpetuados por la URSS con el control de rutas comerciales, proyección de poder e imposición de autoridad y, aún presentes sobre el Mar Negro y el Cáucaso, donde fueron y son articulados el poder marítimo y la política exterior rusas.

\section{La importancia de Crimea para Rusia}

La península de Crimea tiene poco más de 26.000 kilómetros cuadrados sobre la costa del Mar Negro, habitada por los tártaros en el siglo XIV y conquistada por los rusos en el siglo XVIII, tiene dos millones de habitantes, cuya población está constituida por un $60 \%$ de rusos, $24 \%$ de ucranianos y $12 \%$ de tártaros y musulmanes, siendo

\footnotetext{
6 Federación de Rusia. Notación abreviada RU.

7 Congreso de Berlín de 1878. Asamblea diplomática en Berlín (Alemania) -del 13 de junio al 13 de julio de dicho año- por representantes de las potencias europeas, a fin de revisar el tratado de San Stefano devenido de la guerra ruso turca de 1877/78.

8 Primera Guerra Mundial entre 1914/18.

${ }^{9}$ Mapa I. Crimea pasó a dominio ruso después de la guerra civil de 1918/20.

${ }^{10}$ República Federal de Alemania. Notación abreviada DE.

11 Segunda Guerra Mundial entre 1941/44.

12 Unión de Repúblicas Socialistas Soviéticas. Estado federal marxista leninista de Eurasia entre 1922/91. Notación abreviada URSS.

${ }^{13}$ Nikita Serguéievich Kruschev. Primer Secretario del Partido Comunista de la Unión Soviética entre 1953/64 y, Presidente del Consejo de Ministros entre 1958/64. Miembros del partido lo retiraron del poder en 1964.

14 Ucrania. Notación abreviada UA. Independiente con la revolución rusa de 1917, quedando bajo control soviético entre 1920/91 y, nuevamente independiente a partir del 08 de diciembre de 1991 con la constitución de la Comunidad de Estados Independientes (CEI).
} 
su capital Simferopol. Conocida por la Guerra de Crimea ${ }^{15}$ y/o por la Conferencia de Yalta ${ }^{16}$ a fines de la Segunda Guerra Mundial, cuando Roosevelt ${ }^{17}$, Churchill ${ }^{18}$ y Stalin ${ }^{19}$ dividieron Europa y sentaron las bases de la Guerra Fría ${ }^{20}$.

Ucrania y Crimea, son para Rusia parte de su historia cultural y esfera de influencia, la península fue rusa hasta que pasó a dominio ucraniano como República Autónoma de Crimea, conformando una herida en las relaciones bilaterales. Asimismo, en Sebastopol ${ }^{21}$-desde hace 230 años- tiene su base la flota rusa del Mar Negro, influyendo sobre el Mar Mediterráneo, los Balcanes y el Cercano y Medio Oriente. Flota que tiene otro asiento -en su costa del Mar Negro- en Novorossisk, aun así la península se corresponde con el orgullo e imaginario nacional ruso. Por cierto, Vladimir Putin pactó -con el otrora gobierno ucraniano- un acuerdo de permanencia ${ }^{22}$ en Sebastopol hasta 2042, acotando -con ello- la influencia de la OTAN sobre la región. Base que retomó importancia ante la guerra de Georgia, la problemática Libia, la piratería del Océano Índico y en el actual conflicto sirio23.

\section{Otras causas y consecuencias del vigente conflicto}

Los actuales hechos políticos, económicos y militares ucranianos, pusieron de manifiesto un evento sin precedentes, por cuanto la presencia de paramilitares equipados en Crimea, la adhesión de dicho territorio -de facto y de iure- a Rusia y la caída de un régimen relativamente democrático, marcaron un cambio en el derecho internacional. Las causas -entre otras- fueron la herencia de una economía centralmente planificada, un elevado déficit estatal $y$, un presupuesto apoyado en la dependencia energética europea, de hecho el conflicto afectó las bolsas europeas, la cotización del rublo y el tipo de interés en Rusia. Por otra parte, John Kerry²4 dijo sobre la expulsión de Rusia del Grupo de los $O c h 0^{25}$ y, la UE apoyó a la OTAN y condenó la escalada militar rusa.

\footnotetext{
15 Guerra de Crimea 1853/56. Conflicto bélico entre el Imperio Ruso y la alianza del Reino Unido, el Segundo Imperio Francés, el Reino de Cerdeña y, el Imperio Otomano al que apoyaron para evitar su caída y consecuente crecimiento de Rusia.

${ }^{16}$ Conferencia de Yalta. Reunión mantenida durante la Segunda Guerra Mundial -del 4 y 11 de febrero de 1945- entre lósif Stalin, Winston Churchill y Franklin Delano Roosevelt, como jefes de gobierno de la URRS, GB y US respectivamente.

${ }^{17}$ Franklin Delano Roosevelt. Presidente demócrata de US durante cuatro períodos 1932/36, 1936/40, $1940 / 44$ y 1944 hasta su fallecimiento el 12 de abril de 1945.

18 Winston Leonard Spencer Churchill. Primer Ministro de GB en dos períodos 1940/45 y 1951/55.

19 lósif Stalin. Presidente del Consejo de Ministros de la URSS entre 1941/53.

${ }^{20}$ Guerra fría. Enfrentamiento -de 1945 a 1991 - en los ámbitos político, económico y militar iniciado al fin de la Segunda Guerra Mundial entre el bloque occidental (bajo ideología capitalista) liderado por US y el bloque oriental (bajo ideología comunista) liderado por la URSS.

${ }^{21}$ El pensamiento ruso tiene presente el motín en el acorazado Potemkin, atracado en Sebastopol, hecho precursor -entre otros- de febrero y octubre de 1917 que llevaron a la revolución. La flota naval ucraniana, también tenía su cuartel general en la Ciudad de Sebastopol.

${ }^{22}$ A la caída de la URSS, hubo varios acuerdos: el primero entre los presidentes Boris Yeltsin y Leonidas Kravchuk (junio/1992), que dividió la flota y los muelles de la base naval de Sebastopol, el segundo, acordó el uso de dicho puerto de 1997 a 2017 y, finalmente el 21 de abril de 2010, por el pacto de Kharkov, se cedió la base hasta 2042 a cambio de una rebaja del $30 \%$ en el precio del gas, es decir, un ahorro de 40.000 millones de dólares anuales. Acuerdo ratificado por la Duma rusa y resistido por el parlamento ucraniano y, que a pesar del mismo, el precio pagado por Ucrania fue en alza (234 U\$S - junio/2010, 350 U\$S - agosto/2011 y 430 U\$S cada 1000 metros cúbicos - enero/2013). Además, de la dependencia ucraniana de los energéticos rusos, también existe dependencia en el sector agrícola, razón por la que arrendó a China millones de hectáreas del territorio nacional (acuerdo agrícola ucranio - chino / 2013).

${ }^{23}$ La guerra civil Siria provocó un significativo incremento naval ruso y de la OTAN en el mediterráneo oriental, por otra parte en Tartus (Siria), Rusia tiene una base naval desde 1971.

24 John Kerry. Secretario de Estado de US, miembro del partido demócrata y, actual integrante de la administración Obama.

${ }^{25}$ Grupo de los ocho. Notación abreviada G8. Países miembros: Alemania, Canadá, Estados Unidos, Francia, Gran Bretaña, Italia, Japón, Rusia y, representantes de las presidencias de la Comisión Europea y Consejo Europeo.
} 
Crisis que marcó la inestabilidad mundial y una larvada continuidad de la guerra fría, con incidencia de múltiples factores sobre este conflicto. Además, si China ${ }^{26}$-aliado de Rusia- deja de comprar Bonos de la FED ${ }^{27}$, incrementaría la financiación de la deuda y el probable quiebre del sector público estadounidense, que junto al endeudamiento de las economías occidentales, la dependencia energética europea a través de Ucrania y, la globalización de las empresas multinacionales, constituyen servidumbres a la política exterior de Estados Unidos ${ }^{28}$ ante actores como Rusia, China y/o una alianza entre éstos.

Asimismo, entre las causas de Euro Maidán ${ }^{29}$, compiten el acuerdo de libre comercio de la UE y el de la $\mathrm{CEI}^{30}$, a fin de neutralizar la influencia europeo estadounidense sobre las ex repúblicas soviéticas, con economías europeas energéticamente dependientes de Rusia, que en el caso de Crimea, dicha dependencia se reproduce respecto de Ucrania, al recibir de ésta el $80 \%$ del agua potable, el $75 \%$ de la energía eléctrica y la mayoría de los alimentos.

Al mismo tiempo, los problemas ucranianos devienen de 2012, de cuando Kiev incumplió con el FMl ${ }^{31}$ sobre cambios en las pensiones y edad jubilatoria, desregulación empresaria, reforma del sistema financiero y privatizaciones. Temas, que junto a una abultada deuda externa ${ }^{32}$-con emisión de bonos ${ }^{33}$ - estando la economía en recesión, fueron hechos que complicaron el pago a los bonistas. Asimismo, un rescate financiero por parte de Estados Unidos, con reservas ucranianas -probablemente- en territorio estadounidense, a la vez que los eventos -de febrero de 2014generaron una masiva corrida bancaria, sobre todo en Crimea, desestabilizando el sistema financiero, cerrando los créditos a las empresas y escalando la crisis de la economía real.

A todo esto, el gas ruso hacia Europa Central pasa por el gasoducto Soyuz ${ }^{34}$, la otra gran vía -el oleoducto Druzhba- distribuye el $40 \%$ del petróleo ruso hacia la misma región. Por cierto, dentro de la red de oleoductos y gasoductos rusos, están el gasoducto Nordstream (mar Báltico), el gasoducto Yamal-Evropa (región bielorrusa polaca), el gasoducto Soyuz (Ucrania) y, el del Mar Negro hasta Turquía -terminado en 2003- para reducir la dependencia de terceros países. La construcción más importante para la UE, el gasoducto Nordstream, un objetivo ruso alemán para reducir el riesgo-país de las ex repúblicas soviéticas, cuyo costo -sólo en la parte marítima- fue de 7.400

\footnotetext{
${ }^{26}$ La República Popular China se opuso a la imposición de sanciones y se abstuvo en la votación del proyecto de resolución sobre el referéndum de Crimea en el Consejo de Seguridad de la ONU. Embajada de la RPCh, observaciones del portavoz de la Cancillería sobre la votación del Consejo de Seguridad para la Resolución del Problema del Referéndum de Crimea, 16.MAR.14, http://ve.chineseembassy.org/esp/fyrth/t1137831.htm.

${ }^{27}$ Reserva Federal de Estados Unidos de América.

${ }^{28}$ Estados Unidos de América. Notación abreviada US.

${ }^{29}$ Euro Maidán. Denominación dada a los disturbios acaecidos en la plaza Maidán (Kiev, Ucrania) desde la noche del 21/11/2013, de índole europeísta y nacionalista, que derrocó al presidente electo Viktor Yanukóvich del Partido de la Regiones (pro-ruso).

30 Tratado de Libre Comercio de la CEl agrupa a Rusia, Bielorrusia, Ucrania, Kazajstán, Kirguizistán, Tayikistán, Moldavia y Armenia, que supone la progresiva eliminación de trabas aduaneras entre sus miembros.

31 Fondo Monetario Internacional. Notación Abreviada FMI.

32 Ucrania. Deuda externa en 2003 de 69.000 millones y reservas por 9.000 millones de dólares.

33 Bonos ucranianos. Emisión 2012(13 a diez años sobre un interés del 10\%.

34 Mapa II. Gasoducto construido por la URSS, Bulgaria, Hungría, República Democrática Alemana, Polonia y Checoeslovaquia entre $1975 / 78$.
} 
millones de euros. Infraestructura que supone una amenaza para las empresas europeas -especialmente alemanasdependientes dicho suministro, obstruyendo de hecho las sanciones a Rusia. Asimismo, Vladimir Putin ante el Consejo de Seguridad de su país -en diciembre de 2005- hizo manifestaciones a favor de ser una potencia energética, como estrategia en pos de recuperar el liderazgo global.

Igualmente, Gazprom ${ }^{35}$ monopolio productor y exportador de gas ruso, complicó y complica el ingreso de las empresas europeas a la explotación de yacimientos, dependiendo Rusia de la exportación de energía tanto como Ucrania y Europa occidental dependen del gas y petróleo rusos, importaciones que suponen el $25 \%$ del consumo total de la UE. Al tiempo, que la adhesión de Crimea conlleva -para los ucranianos- la negación a los yacimientos del Mar Negro y, consecuente mayor dependencia energética.

\section{Unión de Repúblicas Socialistas Soviéticas a la Rusia actual}

A la fecha, la Federación de Rusia ${ }^{36}$ busca restaurar, a medio y largo plazos, aquel imperio euroasiático en oposición a Estados Unidos de ampliar hacia el este la alianza euro atlántica ${ }^{37}$. Seguramente, la caída de la URSS implicó la atomización del bloque comunista, un agrupamiento euroasiático con debilidad ideológica ante actitudes nacionalistas, acelerado por el fracaso político y socioeconómico del sistema soviético, hechos por los que Rusia, Bielorrusia y Ucrania ${ }^{38}$-el 8 de diciembre de 1991- anunciaran la disolución de la URSS y su reemplazo por una difusa Comunidad de Estados Independientes ${ }^{39}$.

El desplome soviético produjo confusión y vacío de poder regionales, por cuanto sus fronteras retrocedieron en el oeste, el Cáucaso y el Asia Central, restaurando la influencia turca y generando temor ante el islamismo y la posible falta de recursos energéticos y minerales, al tiempo que Ucrania se opuso a un paneslavismo común. Ergo, territorios de la ex URSS pasaron a ser nuevos Estados soberanos, donde habitan 20 millones de ruso parlantes dominados por élites nacionalistas, degradando a Rusia de superpotencia a potencia regional.

Situación agravada por la crisis socioeconómica y la pérdida de posición internacional, que causaron innumerables daños a Rusia, disminuyendo su control sobre los Estados Bálticos, ya que la pérdida de los puertos de Riga y Talin acotaron su acceso a dicho mar y, aunque Moscú mantuvo su estatus sobre Bielorrusia, el nacionalismo y la caída del Pacto de Varsovia ${ }^{40}$, llevó a sus ex satélites de Europa Central a gravitar en la OTAN y UE.

\footnotetext{
35 Gazprom. Monopolio ruso productor y exportador de gas.

${ }^{36}$ Federación de Rusia. Notación abreviada RU.

${ }^{37}$ Alianza euro atlántica u Organización del Tratado del Atlántico Norte. Notación abreviada OTAN.

38 Ucrania. Notación abreviada UA.

${ }^{39}$ Comunidad de Estados Independientes. Notación abreviada CEI.

40 Pacto de Varsovia. Acuerdo de cooperación militar -opuesto a la OTAN- formado en Varsovia el 14 de mayo de 1955 y disuelto en Praga el $1^{\circ}$ de julio de 1991, cuyos integrantes fueron: Albania, Bulgaria, Checoslovaquia, Hungría, Polonia, República Democrática Alemana, Rumania y la URSS, bajo liderazgo de esta última.
} 
Por otra parte, las modificaciones sobre los mares Negro y Caspio y el Asia Central, con Ucrania, Azerbaiyán, Kazajstán y Turkmenistán independientes, dejó a Rusia sin su posición dominante sobre el Mar Negro y como un aspirante más a los recursos del Mar Caspio, que junto a la emergencia de los nuevos Estados centroasiáticos, retrotrajo la frontera sudoriental rusa. Además, estos países -apoyados por Irán ${ }^{41}$, Pakistán, Turquía ${ }^{42}$ y Arabia Saudita- no estuvieron dispuestos a canjear soberanía política por integración económica, sobre todo ante los precedentes de Chechenia ${ }^{43}$ y Tayikistán ${ }^{44}$. Hechos, que hacen suponer un potencial conflicto en sus fronteras sur y sudoriental, donde -con turcos, iraníes y pakistaníes- hay más de 300 millones de musulmanes.

Finalmente, Moscú tiene una nueva situación en el Lejano Oriente, ya que China ${ }^{45}$-durante siglos- fue más atrasada que Rusia en lo político y militar y, hoy por hoy, los rusos saben de la tendencia de Pekín, atento a que su poder económico y la dinámica de sus 1200 millones de habitantes cambiaron la historia bilateral, afectando la seguridad e intereses rusos en Asia Central y el Lejano Oriente. Todo lo cual, dejó a Rusia con pocos accesos y potenciales conflictos en sus fronteras occidental, oriental y sur.

Entonces, si se esperó la quietud rusa ante los sucesos de Kiev, fue un grave error incurrido por occidente y Ucrania, para Vladímir Putin son temas claves su flota del Mar Negro, la base naval de Sebastopol y la península de Crimea, por cuestiones históricas y culturales del nacionalismo ruso y para no mostrar debilidad frente a Euro Maidán, a fin de evitar probables conflictos en su vecindario próximo, en Georgia, Moldavia y/o incluso en Rusia, poniendo en riesgo su poder e influencia. El líder ruso partió de una reacción occidental tibia, de su derecho a veto en el Consejo de Seguridad de la ONU y, de la necesidad que Estados Unidos tiene de Rusia respecto a Irán, Siria y/o Afganistán. De hecho, Vladimir Putin logró la adhesión de Crimea, quiere nuevas negociaciones sobre la región y/o probablemente la integración territorial del este y sur ucranianos y, que los rusos y pro-rusos gocen de garantías en la nueva Ucrania. Por cierto, occidente cometió un grave error, situó a los ucranianos entre Europa y Rusia -en un todo o nada- sumiendo el país en una grave crisis.

\footnotetext{
${ }^{41}$ República Islámica de Irán. Notación abreviada IR.

42 República de Turquía. Notación abreviada TR.

43 Conflicto ruso chechenio $1994 / 96$ y $1999 / 00$.

44 Guerra civil de 1992/97que enfrentó a diversos clanes. Tropas rusas estuvieron estacionadas en el sur de Tayikistán -en la frontera con Afganistán- hasta mediados de 2005 para garantizar estabilidad y evitar incursiones islamistas.

${ }^{45}$ República Popular de China. Notación abreviada CN.
} 


\section{CAPÍTULO II}

\section{PLANTEAMIENTO Y JUSTIFICACIÓN DEL PROBLEMA}

¿ Existe asociación entre la adhesión territorial de la República Autónoma de Crimea y la misión de la Federación de Rusia ? Trabajo de investigación exploratorio descriptivo, que corre entre el 21 de noviembre de $2013^{46}$ y el 21 de marzo de 2014 inclusive, que justifica la tarea sobre el objeto de estudio, el proceso de adhesión de la República Autónoma de Crimea subsumido en el conflicto ruso ucraniano. A desarrollar dentro del marco teórico metodológico ${ }^{47}$ dado por el Doctor Federico Frischknecht y otros en lógica, teoría y práctica de la estrategia y, ante la necesidad de confirmar -acorde la hipótesis- si la misión del protagonista y la adhesión de la citada república están asociados. Cuestión a contrastar mediante intereses, actores, trama y escenario, atento a que Rusia mantuvo la comunicación a través de cierto discurso dirigido a la UE y OTAN y, en particular a Ucrania, afirmando -con hechosel mensaje de Vladimir Putin de que Georgia y Ucrania son los límites a dichas organizaciones.

\section{Objetivo general}

- Describir si existe asociación -en el tiempo aludido- entre la misión del protagonista y la adhesión de la República autónoma de Crimea dentro del conflicto ruso ucraniano.

\section{Objetivos específicos}

- Obtener información documental sobre el conflicto dentro de la brecha temporal indicada.

- Aplicar el marco teórico metodológico dado por el Doctor Federico Frischknecht y otros.

- Explorar si existe mutua influencia entre la misión rusa y la adhesión de la citada república.

\section{Alcances}

Establecer un marco teórico metodológico que permita explorar y describir la realidad respecto de la asociación planteada y, si fuese necesario -en un futuro- continuar explorando desde lo académico la relación ruso ucraniana.

\footnotetext{
${ }^{46}$ Viktor Yanukovich -21 de noviembre de 2013- decisión contra la UE. Presidente electo democráticamente en 2010, cambió la constitución en pos de más poderes. Líder del Partido de las Regiones con otrora mayoría parlamentaria. Estimó su caída como un golpe de Estado y abandonó Kiev -hacia Rusia- por temor a represalias.

${ }^{47}$ ALONSO, Rodolfo J.; FRISCHKNECHT, Federico; HERNÁNDEZ OTAÑO, Felipe; LANZARINI, Mario S. T.; MOYA LATRUBESSE, Eulogio A. Op. cit.
} 


\section{CAPÍTULO III}

\section{MARCO TEÓRICO METODOLÓGICO}

\section{El realismo y las relaciones mundiales}

En el campo de las relaciones mundiales ${ }^{48}$ el realismo trata las conductas e interacciones de los actores soberanos y, aún carece de una comprensión holística de los sucesos mundiales. Además, lejos de una teoría unificada, el realismo tiene tres elementos distintivos ${ }^{49}$ : (i) el Estado como legítimo representante de las aspiraciones colectivas y, después de Westfalia ${ }^{50}$, como actor fundamental del sistema internacional, (ii) el principio de soberanía estatal como supremacía legal por sobre cualquier otra autoridad en un cierto territorio y, (iii) la supervivencia como prioridad estatal. Asimismo, existieron y existen diferentes versiones del realismo, siendo sus mayores exponentes: Tucídides $^{51}$ (La guerra del Peloponeso-400 a. c.), Maquiavelo52 (El príncipe-1532), Hobbes ${ }^{53}$ (Leviatán-1651) y Rousseau $^{54}$ (Estado de guerra-1750), sobresaliendo en el siglo XX, Hans Morgenthau ${ }^{55}$ (Política entre las naciones-1948) y Kenneth Waltz ${ }^{56}$ (Teoría de la política internacional-1979), categorizados hasta el siglo XX como realistas clásicos, realistas modernos hasta los 70 con Morgenthau y, realismo estructural o neorrealismo con Waltz desde 197957.

El realismo estructural o neorrealismo waltziano planteó dos postulados básicos para la política internacional, estructura y unidades interactuantes (elementos del sistema), siendo los Estados -aunque admite otras- las unidades básicas. Su analogía sobre las estructuras reguladoras de los sistemas políticos internos (Estado) e internacional, le permitió situar diferencias, la interna centralizada y jerárquica con unidades de control y subordinación (de mando y obediencia), mientras que las unidades del sistema político internacional -descentralizadas y anárquicas (opuestas a la jerarquía)- son formalmente iguales y sin relaciones de control y subordinación.

Entonces, en la estructura política interna, las relaciones entre las unidades de control y subordinación implican la diferenciación de funciones, mientras que entre las unidades de la estructura política internacional no existe tal distinción, ya que con más o menos recursos, complejidad y probabilidades de éxito, éstas son básicamente las

\footnotetext{
${ }^{48}$ Relaciones mundiales, no relaciones internacionales, por cuanto -hoy por hoy- existen vinculaciones entre Estados, organismos supra estatales, organizaciones no gubernamentales (ONG's), empresas multinacionales, actores transnacionales y demás.

${ }^{49}$ Las tres "S" de la teoría realista: State (Estado), survivor (supervivencia) y self help (autoayuda).

$50 \mathrm{Paz}$ de Westfalia. Fin de la Guerra de los Treinta Años mediante los tratados de Osnabrück y Münster (15/mayo y 24/octubre/1648).

51 Tucídides. 460 a 396 a. C.) Historiador y militar ateniense, cuenta la guerra entre Atenas y Esparta, siglo V a. C.

52 Maquiavelo, Nicolás. 1469 a 1527. Diplomático, funcionario público, filósofo político y escritor italiano del Renacimiento, considerado el padre de la ciencia política moderna.

53 Hobbes, Thomas. 1588 a 1679. Filósofo inglés, teórico del absolutismo político.

${ }^{54}$ Rousseau, Jean Jacques. 1712 a 1778 . Filósofo, escritor, pedagogo y naturalista suizo francés.

55 Morgenthau, Hans Joachim. 1904 a 1980. Abogado y político alemán americano.

56 Waltz, Kenneth Neal. 1924 a 2013. Politólogo estadounidense, fundador del realismo estructural o neorrealismo.

${ }^{57}$ Otra clasificación distingue a Morgenthau -como Tucídides y Hobbes- fijando pie en la naturaleza humana y, a Waltz en la estructura del sistema internacional.
} 
mismas, estando sus desigualdades en las capacidades y no en las funciones. Por cierto, los conflictos internacionales propios de la descentralización, anarquía y falta de diferenciación funcional, sigue el principio de autoayuda, lo que un Estado gana y pierde en el sistema internacional depende de sus capacidades (poder) y esfuerzos, sobre todo aquellos dirigidos a preservar su supervivencia.

Por otra parte, la conflictividad internacional -según Waltz- no se puede superar, de ahí su pesimismo sobre la interdependencia e integración de los Estados, considerando que la interdependencia entre las unidades requiere de -previa- especialización, la que se da en una estructura jerárquica por vinculaciones de control y subordinación, propia del interior de los países, razón por la que no existe la interdependencia entre los mismos. Respecto a la integración, ésta se opone a la anarquía del sistema internacional, por cuanto todo Estado teme: (i) que en un proceso de integración sus ganancias relativas sean menores a las de su socio y, (ii) que subsumido en dicho proceso, incremente su dependencia negando el principio de autoayuda. Siendo las ganancias económicas subordinadas a la seguridad y, los postulados en política interior la especialización y, en política internacional la supervivencia, aun así consideró que los conflictos pueden controlarse a través de la amenaza de violencia. Por cuanto en la estructura política interna -centralizada y jerárquica- el monopolio legítimo del uso de la fuerza está en manos gubernamentales, mientras que en el sistema político internacional descentralizado y anárquico, los Estados tienen las opciones del cuándo y cómo hacer uso de la misma, describiendo a la anarquía -en sí misma- como un estado de guerra, constituyendo el riesgo bélico lo que sitúa a los actores dentro de lo previsible, reivindicando así el equilibrio de poder.

\section{Nuevo orden mundial}

Después de 1991 se dijo de un nuevo orden mundial, pero caído un orden no surge otro espontáneamente, sino mediante un proceso previo que requiere de tiempo para su nacimiento, desarrollo y consolidación, es decir, que entre la caída de un orden y la emergencia de otro, deben resolverse una gran cantidad de temas respecto a las relaciones entre los Estados y entre éstos y otros actores. Entonces, bajo una perspectiva realista sistémica estructural ${ }^{58}$, importa conocer el escenario de las relaciones internacionales 0 -mejor dicho- mundiales, cómo son las interacciones entre los actores y en qué áreas, si existe continuidad o no en el tiempo, los factores causantes del cambio y la estabilidad y demás, ya que la comunidad mundial sigue pautas de ordenamiento y gobierno distintas a las del Estado, prevaleciendo en este último la centralización y jerarquía y la capacidad suprema ${ }^{59}$ de fijar normas. Mientras que a nivel mundial la regla está en la defensa soberana ${ }^{60}$, por cuanto los Estados no admiten -o tienden a no admitir- la imposición de condiciones por órganos supra estatales, ya que sólo acuerdan entre ellos, imponen y/o se nie-

\footnotetext{
58 Dallanegra Pedraza, Luis. El Orden Mundial del Siglo XXI. Capítulo I. Ediciones de la universidad, Buenos Aires, Argentina. 1998. C:IDocuments and Settings VcarolMis documentosITIFIPolítica Internacional, Relaciones Internacionales. DALLANEGRA PEDRAZA.mht

${ }^{59}$ Aquellos que -de forma consensual o coercitiva- tienen la capacidad de instalar reglas.

60 Hoy por hoy, resulta difícil seguir el principio de defensa soberana, por cuanto los actores transnacionales operan desde el interior de los Estados, imponiéndoles reglas, incluso a los más poderosos.
} 
gan a ser impuestos. De tal forma, que tendiendo a la anarquía cada cual defiende su juego más que la organización y, en ausencia de órganos superiores con el monopolio legítimo del uso de la fuerza (como las administraciones al interior de los Estados), los actores más poderosos son quienes -en definitiva- gobiernan el sistema.

Ciertamente, las relaciones mundiales tienen ingredientes esenciales (históricamente perdurables) e ingredientes accidentales (variables) según pautas culturales, civilizatorias y de desarrollo científico tecnológico. También, todo vínculo requiere de elementos materiales para su desarrollo y consolidación (factores económicos), seguridad en su entorno y ante otros (factores estratégico militares) y, una organización con un gobierno capaz de mantener el orden establecido (factores políticos). Ergo, vinculaciones mundiales que se realizaron y realizan sobre tres grandes ejes: (i) el económico61, que proporciona las necesidades materiales de una sociedad, con poder material propio mediante la industria, la ciencia y técnica, el comercio y las finanzas, junto a las estrategias desarrolladas o en desarrollo y las alianzas económicas para mejorar el desempeño, (ii) el estratégico militar², que otorga la defensa y seguridad necesarias, también con poder material propio, dado por los ejércitos, las armas, las estrategias desarrolladas o en desarrollo y las alianzas militares para fortalecer el desempeño y, (iii) el político63, que fija el orden para que las necesidades materiales y la seguridad se satisfagan de una cierta forma, con poder de influencia -pero sin poder material propio- en pos de sus objetivos, de ahí su relación con los otros dos ejes. A pesar de ello, este último representa el cerebro, el eje planificador, aquel que establece las condiciones del sistema mundial ${ }^{64}$, los valores y creencias, las pautas de justicia y de equilibrio del mismo ${ }^{65}$. Estos tres ejes, bajo formas de interacción diferentes, determinan el orden y funcionamiento del sistema ${ }^{66}$ a través del eje en el que predomina el poder básico, el económico o estratégico militar, siendo el poder la variable crítica. Además, el conocimiento y el avance científico tecnológico modifican a estos dos últimos ejes, a la vez que las alianzas surgen de valores, ideologías y/o intereses ${ }^{67}$.

${ }^{61}$ Eje económico, formado por los segmentos de relacionamiento como industria, ciencia y técnica, comercio y finanzas.

62 Eje estratégico militar, formado por los segmentos de relacionamiento como ejércitos, armas, estrategias y alianzas.

63 Eje político, formado por los segmentos de relacionamiento como orden, justicia, alianzas y equilibrio.

${ }^{64}$ El sistema mundial resulta del conjunto de actores -Estados, empresas multinacionales, actores transnacionales, organizaciones no gubernamentales-ONG's, organismos supra estatales y demás- que interactúan y se condicionan mutuamente mediante alianzas y/o asociaciones en pos de sus intereses haciendo uso del poder. El sistema mundial, dependiendo de la cantidad de actores polares, puede ser bipolar (EEUUURSS entre 1945/47 y 1989/91), multipolar (Inglaterra, Francia, el Imperio Austro Húngaro, Prusia y Rusia entre 1815 y 1914) o unipolar (imperios históricamente conocidos).

65 Equilibrio del sistema. Intervienen todos sus integrantes en un mundo con miembros heterogéneos. Equilibrio entre actores polares o entre actores que actúan, aquellos que poseen una política exterior de acción y no de reacción, con capacidad de fijar reglas y/o modificarlas en su propio beneficio, el resto constituyen unidades adscriptas. Cuando los actores polares intervienen sobre una unidad adscripta -bajo su influencia- para restablecer o mantener el equilibrio del sistema, refiere al equilibrio que fue (o pudo ser) quebrado (temporaria o definitivamente) por otro actor polar en su beneficio. La unidad intervenida, sino cambia su estatus, quedará subordinada a los intereses del actor hegemónico, p.ej.: las intervenciones de la URSS -mediante el Pacto de Varsovia- en Hungría (1956/58) y en Checoslovaquia (1968).

66 Funcionamiento del sistema. Relacionamiento horizontal de los actores polares: pugna por hegemonía (bipolaridad-guerra fría) o competencia entre opuestos (multipolarismo-siglo XIX). Relacionamiento vertical: grado de permisividad de los actores polares a las conductas de los integrantes bajo su influencia y, la resistencia -por abajo- de las unidades adscriptas (hegemonizadas). En un sistema bipolar de mucha tensión entre polos, la permisividad vertical será baja y la resistencia escasa. En un sistema multipolar, donde la ideología no resulta central como en la bipolaridad, el desempeño independiente de los hegemonizados tiende a ser mayor. Por cierto, en un sistema bipolar, los actores adscriptos no pueden vincularse libremente con ambos polos, mientras que en el multipolarismo las unidades hegemonizadas poseen mayor autonomía.

${ }^{67}$ Las alianzas mediante la relación de los ejes político y estratégico-militar / bloques de seguridad y, a través del vínculo de los ejes político y económico / bloques económicos de integración. Por cierto, entre desiguales y por afinidad entre actores, p. ej.: el TIAR conformado por integrantes desiguales en lo militar / EEUU y países latinoamericanos. 
3. El conflicto ruso ucraniano bajo una perspectiva realista sistémica estructural

El actual conflicto ruso ucraniano, presenta los tres elementos característicos de la teoría realista, (i) el Estado como legítimo representante de las pretensiones colectivas y actor fundamental del sistema internacional, (ii) el concepto de soberanía estatal -como supremacía legal- por sobre cualquier otra autoridad en un determinado territorio y, (iii) la supervivencia como prioridad estatal, donde el poder resulta ser la variable de peso. Entonces el presente conflicto, visto desde una perspectiva realista sistémica estructural de las relaciones mundiales, sigue reglas de ordenamiento y gobierno distintas a las del Estado, donde la defensa soberana en pos de la supervivencia estatal constituye la pauta a seguir. Por cuanto Rusia, Ucrania y los otros actores acuerdan entre ellos, imponen y/o evitan ser impuestos, tendiendo a la anarquía, el caos, donde cada uno defiende sus intereses, siendo los más poderosos quienes -en definitiva- manipulan el conflicto dentro de las relaciones mundiales.

Vinculaciones desarrolladas bajo ingredientes esenciales (constantes) y accidentales (variables) según sus culturas y desempeños en ciencia y técnica, resultando los factores interrelacionados entre Rusia y Ucrania semejantes en lo cultural, religioso, civilizatorio y científico tecnológico, ya que sus mayorías poblacionales son partes de la nación eslava. De hecho, ambos poseen elementos materiales para su consolidación y progreso (componentes económicos), seguridad en su entorno y frente a otros (componentes estratégico militares) y, gobiernos capaces de mantener el orden establecido (componentes políticos), pero con diferentes capacidades y recursos cuantitativos- que denotan el desequilibrio de poder existente ${ }^{68}$, siendo sobre todo Rusia -no Ucrania- una potencia nuclear, de ahí sus respectivas alianzas (por valores, ideologías y/o intereses) con otros actores. Hoy por hoy, las relaciones entre ambos Estados y las de éstos con los demás actores involucrados, apoyadas en los ejes económico, estratégico militar y político relacionados de diferentes modos, fijan el orden (estructura ${ }^{69}$ ) y el régimen ${ }^{70}$ del sistema mediante el eje estratégico militar, donde predomina el poder básico y del que deviene el mismo como variable crítica.

\section{Adhesión de la República Autónoma de Crimea (dialéctica de voluntades)}

Efectivamente, la racionalidad o relación entre medios y fines -esencia de la decisión estratégica rusa- le permitió hacer uso de los medios apropiados hacia el logro de sus fines. Por supuesto, Rusia no estuvo sola, existieron otras entidades -con intereses coincidentes y/o discrepantes- que interfirieron en el libre uso racional de sus

\footnotetext{
${ }^{68}$ Disimetría y asimetría en un conflicto. En las guerras convencionales -bajo la teoría del desgaste- los Estados involucrados buscan la disimetría y no la asimetría. Disimetría: diferencia cuantitativa entre fuerzas beligerantes. Asimetría: diferencias cualitativas en los valores, experiencias y conocimientos en y sobre los medios empleados.

${ }^{69}$ Estructura. Orden y distribución de las partes de un todo. Aristos, diccionario ilustrado de la lengua española. Editorial Ramón Sopena S.A., Barcelona, España, 1978, pp. 278.

70 Régimen. Conjunto de normas que gobiernan o rigen una cosa o una actividad. Diccionario de la Real Academia Española, $1^{\text {a }}$ edición. Editorial Espasa Calpe S.A., Madrid, España, 1996, pp. 963.
} 
medios, cooperando o compitiendo en obvia interacción. Entonces, emanó la racionalidad interdependiente -como una de las características de la estrategia ${ }^{71}$ - actuando el protagonista acorde la acción de los demás, que condicionado por otra u otras voluntad/es inteligente/s afectó/ron su libertad de acción, conforme percibieron aliados y opuestos los efectos sobre si, determinando el intercambio de mensajes (comunicación) mediante actitudes, verbalizaciones, posturas y/o el acto de fuerza.

Indudablemente, las diversas conducciones estratégicas utilizaron el diálogo -a través de la palabra y/o la acción- para influir en los acontecimientos, es decir que cada actor tomó decisiones en interacción con aliados y contrarios, propio de una dialéctica de voluntades. Las comunicaciones de aliados y opuestos fueron criticadas, dando paso a nuevos mensajes que -en un ciclo de prueba y error- fueron nuevamente cuestionados, hasta que se logró -entre las partes- un discurso uniforme y cierto compromiso -como solución transitoria- ante la cuestión de fondo del conflicto. Entonces, la dialéctica mejoró la representación que cada actor tuvo sobre la misma situación, permitiendo la incertidumbre el intercambio de mensajes como forma de aprendizaje, ya que toda decisión estratégica dependió de la respuesta de los otros actores. Por cierto, Rusia comunicó a las partes sus valores, experiencias y conocimientos, a la vez que impuso sus intereses mediante el contenido, autoridad y argumento de sus mensajes.

\section{Inteligencia estratégica}

\subsection{Situación estratégica}

Los antecedentes que sitúan el conflicto son los objetos y valores, los primeros surgen de un análisis del escenario y los segundos de asignaciones subjetivas de los participantes y, siendo la situación estratégica la representación del conflicto interpretada por el actor protagonista, tenemos que la representación construida y asignada a Rusia determina -en un escenario- las relaciones existentes entre sus intereses y los de los otros actores, razones para la reunión de datos como intereses, actores, espacios y reglas de juego. Por cierto, el inicio del proceso lo otorga la misión rusa fijando objetivos según sus intereses, a la vez que otros intereses vinculados a los suyos, permiten el reconocimiento de los demás actores para la posterior construcción de la trama del conflicto.

\subsubsection{La Federación de Rusia como protagonista y la emergencia de su misión}

Los países centro orientales europeos -a partir de 1991- pasaron a manejar sus destinos, indicando el fin de la puja este oeste la derrota de la URSS, la unificación alemana, la primera expansión de la OTAN con su permanencia en Alemania y la liberación de la tutela soviética. Entonces, Mikhail Gorbachov ${ }^{72}$ y Boris Yeltsin ${ }^{73}$, concluyen-

\footnotetext{
${ }^{71}$ Características de la estrategia: racionalidad interdependiente, libertad de acción, dialéctica e incertidumbre.

72 Mikhail Serguéievich Gorbachov. Abogado y político. Presidente de la Unión Soviética 15/03/1990 - 25/12/1991.
} 
do en lo malo del comunismo, lideraron un proceso político del que surgieron tres concepciones ideológicas: libera$\underline{\text { les}}$, centristas y nacional conservadores. Los primeros siguieron el modelo occidental, ya que Rusia debía recuperar su identificación con occidente. Los segundos, estimaron que la relación con occidente debía contener -además de los intereses nacionales- el otrora espacio soviético (el extranjero próximo). Mientras que los terceros, defendieron una visión externa propia opuesta a un occidente no interesado en la inclusión y recuperación rusas, al tiempo que apoyaron una reconstrucción de las fronteras zaristas soviéticas.

Ahora bien, mientras Rusia asumió una política exterior en pos del apoyo occidental para sus reformas y regreso relevante, Estados Unidos desarrolló un enfoque -propio de la Guerra Fría- contrario a Moscú y centrado en maximizar su poder. Lógica de la política exterior estadounidense, que en ausencia de otro poder bajo el principio de equiparación de medios (relación de recursos entre potencias preeminentes), le permitió evitar una nueva amenaza estatal a su superioridad. Ergo, vía medios duros y blandos de poder, los estadounidenses fijaron sus preferencias, ampliaron la OTAN e incumplieron lo pactado al fin de la Guerra Fría.

Hoy por hoy Rusia, en un tiempo de confusión histórica, debate sobre si una Ucrania independiente debe tomarse -histórica, estratégica y étnicamente- como una situación transitoria, por cuanto (en el devenir de los tiempos) "la Rus" siempre buscó la expansión territorial y el desarrollo económico, adoptando para sí una misión supra nacional, determinada en términos paneslavistas, religiosos, ideológicos y geopolíticos. Entonces, cuando territorialmente se redujo y lo étnico adquirió significado, surgió -después de la URSS- aquellas tres opciones: (i) los liberal atlantistas mediante una asociación estratégica madura con Estados Unidos a favor de un condominio global, (ii) los centristas y el extranjero próximo -como interés prioritario- con sus variantes y, (iii) los nacional conservadores a través de una contra alianza euroasiática a la influencia europea y estadounidense en Eurasia.

Por cierto, Boris Yeltsin tomó la postura de que Rusia pertenece y debe formar parte de occidente e imitar su desarrollo, estimulados por Estados Unidos a favor de una asociación estratégica madura a modo de un nuevo condominio global, donde todo conflicto mundial tendría la participación y/o permisos rusos. Asimismo, Europa Central seguiría bajo su influencia y, la disolución del Pacto de Varsovia y del Comecon ${ }^{74}$ no daría lugar a que sus exmiembros fueran atraídos por la OTAN y UE, a la vez que la ayuda occidental afirmaría la democracia y alejaría el Estado de la economía. Entonces, la recuperación económica y su estatus de socio igualitario de Estados Unidos, llevaría a los países de la CEI a una mayor integración política y económica, afirmando Rusia su poder e influencia.

Opción que cayó por su propio peso, ya que los estadounidenses no quisieron compartir el poder global con una Rusia desgastada y en oposición a sus intereses, adquiriendo mayor importancia -para Washington- Alema-

\footnotetext{
${ }^{73}$ Boris Nikoláievich Yeltsin. Presidente de la Federación de Rusia 10/07/1991 - 31/12/1999.

${ }^{74}$ Comecon. Consejo de Asistencia Económica Mutua.
} 
nia, Japón y China. Asimismo, el desproporcionado poder político, económico financiero e innovación tecnológica, hizo de la asociación estratégica madura una meta sin sentido, al tiempo que los rusos no percibieron el crecimiento europeo en la OTAN. La élite rusa sostuvo y sostiene que el crecimiento de dicha organización representa una mayor influencia de Estados Unidos y, mantuvo y mantiene la esperanza de que una Europa Central -no vinculada a la alianza- retorne a su esfera de influencia.

En suma, Rusia esperó la colaboración -y/o la no interferencia- occidental para recuperar su rol en el espacio postsoviético, razón por la que tomaron a mal la ayuda a los nuevos países, sobre todo la relación Estados Unidos Ucrania en oposición a sus intereses. Estos hechos, juntó a la crisis por distanciar el Estado de la economía, generaron falsas expectativas respecto a occidente, favoreciendo a quienes sostuvieron que dicha asociación estratégica fue una estafa estadounidense.

Entonces, irrumpió la prioridad en el extranjero próximo a modo de reconstruir cierto marco -centrado en Moscú- para la toma de decisiones dentro del otrora espacio soviético. Opción que planteó centrarse en los nuevos Estados independientes, ya que éstos atados a realidades políticas y económicas promovidas por Moscú, constituyen un espacio común a no ser ignorado. De hecho, la cooperación y cierta integración -como necesidad ante la caída de la URSS- no fue una política sincera de cooperación económica regional, por cuanto Rusia atacando la política antirrusa de Ucrania y los nuevos Estados y, en supuesta asociación estratégica con occidente, intentó regular temas de Europa Oriental, Asia Central y el Lejano Oriente.

Además, los rusos mantuvieron y mantienen presencia militar en lo que fue la zona soviética, ya que una línea imaginaria por sus bases desde Kaliningrado, Moldavia, Crimea, Armenia, Tayikistán y las islas Kuriles, muestra -prácticamente- el límite exterior de la ex URSS, pudiendo citarse -sobre la CEI- como objetivos rusos: (i) reforzar las relaciones político militares -bajo un mando militar común- a través de un tratado, (ii) decidir sobre el mantenimiento de la paz interior, (iii) controlar las fronteras exteriores de la comunidad y, (iv) fijar la política exterior con instituciones y centro en Moscú y -no en Minsk según acuerdo de 1991- con cumbres presididas por el presidente ruso. Seguramente, el fracaso parcial -de estos objetivos- llevó a la doctrina del euroasianismo, centrada también en los países cercanos y en la mística rusa de una identidad política y cultural euroasiática. Afinidad que deviene del histórico control imperial ruso -desde Europa Central al Océano Pacífico- asimilando a una cuantiosa población no rusa y no europea. El euroasianismo como alternativa al comunismo y opuesta a occidente, según la cual el comunismo traicionó la mística, mientras el mundo occidental percibido como corrupto y antirruso, niega a la madre patria sus legítimas pretensiones -históricas y geográficas- sobre el territorio continental euroasiático.

Prioridad en el extranjero próximo -que por cuestiones de seguridad y económicas- permitió acuerdos entre Rusia y los nuevos Estados independientes, sin embargo lo poco práctico fue pensar que forzados por la econo- 
mía y/o para recuperar el poder perdido, la integración política del otrora imperio fuera posible. Por cierto, los nuevos países vieron a Rusia políticamente inestable, con intenciones de dominación y como un obstáculo a la economía global y a los capitales extranjeros. La mayor negación devino de Ucrania, cuyos líderes percibieron en la integración una pérdida de soberanía, además del trato duro, los derechos sobre Crimea y el control ruso sobre el puerto de Sebastopol. Hechos vistos como tácticas imperiales, que incrementaron sentimientos contra una comunidad eslava junto a Rusia y Bielorusia, como asimismo, opuestos a una CEI más integrada y posterior unión euroasiática.

Las decisiones ucranianas -a mediados de los 90- tuvieron el apoyo occidental, sobre todo de alemanes y estadounidenses, que definieron el vínculo Estados Unidos Ucrania como de asociación estratégica. Indudablemente, una restauración imperial -mediante la CEI y/o el euroasianismo- no puede ser viable sin Ucrania, por cuanto una Rusia sin Ucrania sería menos europea y más asiática. Además, en los nuevos países el creciente nacionalismo y repudio a las pasadas imposiciones soviéticas, permitió la creación de un bloque -bajo liderazgo ucraniano- opuesto a las pretensiones rusas de usar a la CEI como instrumento de unidad político militar, donde la insistencia ucraniana -en acotar la integración a lo económico y comercial- le quitó significado al pensamiento paneslavista. En suma, Rusia -en su prioridad en el extranjero próximo- tuvo un fracaso parcial, debido a su falta de fortaleza política y económica para imponer y/o seducir a los nuevos Estados, mientras que su misión euroasiática y mística eslava la distanciaron de occidente, perpetuando la crisis postsoviética, retrasando la sociedad rusa y vinculando el Asia Central con Europa, China y los Estados islámicos.

A la sazón, caídas las opciones de asociación estratégica madura y prioridad en el extranjero próximo, ciertos líderes rusos buscaron -con China e Irán- una contra alianza euroasiática, interesados también en reducir la influencia estadounidense en Eurasia. Siendo su inicio el comercio de armas entre chinos e iraníes, la disposición rusa de cooperar -en materia nuclear- con Irán, el vínculo ruso chino contra Estados Unidos y la respuesta de Moscú al crecimiento de la OTAN, pero chinos e iraníes fueron cautelosos para no perder inversiones y tecnología occidental. Asimismo, China con mayor población, industria, dinamismo y potenciales ambiciones sobre territorio ruso y ante una Rusia -posiblemente- relegada, persiste a favor de un Estado tapón entre la expansión europea y su territorio.

En suma, sin una asociación estratégica madura, ante la desconfianza de una mayor integración político militar, económica y comercial dentro del otrora espacio soviético y, ante la cuidadosa conducta china e iraní, los rusos tomaron -junto a criterios paneslavistas- elementos de sus políticas de prioridad en el extranjero próximo y de contra alianza euroasiática, a modo de contención a la UE y OTAN y en pos de una alianza contra Estados Unidos y Europa. 
Innegablemente, el protagonismo otorgado a Rusia -entre todos los actores- está en individualizarla para comprender mejor su discurso ${ }^{75}$, constituye un ente privilegiado, que caracterizado por su misión permite identificar sus intereses y los de los otros actores. Además, dicha misión implica el juego histórico de intereses de los conducidos y no una concepción unilateral de los conductores, siendo el nexo entre el frente interno y externo, ya que el conflicto ruso ucraniano no evoluciona en un solo plano, por cuanto la conducción estratégica rusa tiene dos problemas relacionados, uno interno y otro externo. Sin una mínima unidad interna Rusia no puede encarar una situación externa, a la vez que una crisis externa puede dañar su cohesión interna, es decir que el vínculo entre lo interno y externo, está dado por la misión que adoptaron sus dirigentes. Ergo, en el actual conflicto ruso ucraniano, todo actor representa -como suma de voluntades- a los grupos sociales de los que emerge su misión.

\subsubsection{Federación de Rusia: misión}

Imponer límites a la expansión de la UE y OTAN evitando el ingreso de Ucrania a dichas estructuras, adherir la República Autónoma de Crimea preservando la posición estratégica sobre el mar Negro y su correspondiente proyección naval, intervenir en cualquier lugar, circunstancias y bajo las formas y con los medios apropiados, defendiendo los intereses nacionales y/o población rusa y/o pro-rusa amenazada. Además, asistir económica y financieramente a Ucrania evitando la intervención extranjera en los asuntos ucranianos, a la vez que establecer con los miembros de la CEI una mayor integración político militar y económica y, construir una contra alianza estratégica junto a China e Irán- restaurando la imagen e influencia sobre las ex repúblicas soviéticas, a favor de lograr la unidad euroasiática recuperando el otrora liderazgo con incidencia en los asuntos globales.

\subsubsection{Actores}

El actor puede ser un individuo, grupo, empresa, Estado u organismo internacional, que representa una entidad a la cual -en una situación- le otorgaron intereses considerados como fines o medios. Asimismo, en el análisis de un conflicto un actor existe sólo si tiene intereses en el mismo, caso contrario no tuvo -en un escenario- la voluntad de darle diferentes valores a los mismos objetos.

\section{(i) Federación de Rusia (protagonista)}

La Federación de Rusia -como actor protagonista- constituye un ente decisorio, capaz de asumir un número de posiciones sin perder identidad, de modificar la situación y de tener voluntad. Entonces, la situación estratégica

\footnotetext{
75 Discurso. Interpretación holística como continente de actitudes, verbalizaciones, posturas y/o conductas.
} 
-representación del conflicto- construida y asignada a Rusia, contiene cinco actores geoestratégicos ${ }^{76}$ claves y dinámicos como Rusia, Estados Unidos, Alemania, Francia y China y, cinco pivotes geopolíticos ${ }^{77}$ como Ucrania, Gran Bretaña, Polonia, Turquía e Irán, desempeñando -estos tres últimos- un rol geopolítico importante, aunque sólo Turquía e Irán -en la medida de sus capacidades- son también jugadores geoestratégicos.

(ii) Ucrania

Pivote geopolítico, cuya independencia modifica a Rusia, susceptible de conflictos con los nuevos países de Asia Central apoyados por los Estados islámicos del sur. Entonces, una Ucrania no independiente sobre el Mar Negro, con sus 52 millones de habitantes y sus grandes recursos bajo control moscovita, convertiría a Rusia en un imperio euroasiático situando a Polonia en el pivote geopolítico oriental de la UE. Razones, por las que Ucrania solicitó ayuda, por cuanto su interés en asociarse a la unión ${ }^{78}$ y posterior ingreso a la OTAN, colisionó con los intereses rusos de contención a dichas organizaciones. Asimismo, negoció con Rusia el abastecimiento y precio del gas y el incremento de ganancias por el tránsito de dicho fluido. A la vez, que junto a países occidentales y foros internacionales, solicitaron el inmediato retiro de las tropas rusas y el desarme de las fuerzas de autodefensa.

Previo a la actual crisis, la oposición a Rusia fue particularmente fuerte, en razón de que los líderes ucranianos vieron en una integración -político militar- una pérdida de soberanía. Además, el trato duro, los derechos sobre Crimea, el control ruso sobre el puerto de Sebastopol y la existencia de recursos energéticos próximos a la península, incrementaron los sentimientos contra una comunidad eslava -junto a Rusia y Bielorusia- y opuestos a una unión euroasiática. La decisión ucraniana de mantener su integridad territorial tuvo el apoyo de Estados Unidos y Alemania, igualmente el euroasianismo no atrapó a los países de Asia Central y, la postura ucraniana quitó significado al paneslavismo, dejando a Bielorrusia sola y a un Kazajistán -potencialmente- fragmentado con su población rusa del norte.

(iii) Estados Unidos de América

Activo jugador geoestratégico global, socio indispensable en la seguridad y estabilidad del contexto euro atlántico, con valores comunes y estrechas relaciones con Europa, a la vez que promotor de una visión ampliada de la seguridad, cuyas cuestiones a mitigar -entre otras- se relacionan con la inmigración irregular, el narcotráfico, los

\footnotetext{
${ }^{76}$ Actores geoestratégicos activos. Estados que tienen la capacidad y voluntad de ejercer poder y/o influencia allende sus fronteras modificando el estado actual de las cuestiones geopolíticas. Asimismo, no todos los países poderosos, son automáticamente jugadores geoestratégicos.

77 Pivotes geopolíticos. Estados cuya importancia no se deriva de su poder, sino de su situación geográfica y de su potencial vulnerabilidad ante la conducta de jugadores geoestratégicos. Por cierto, definidos por su geografía, que les otorga cierto rol, como el de permitir el acceso a zonas importantes y/o el de negar ciertos recursos. De este modo, pueden actuar como escudo defensivo para un Estado y/o una región vital. A veces, su mera existencia tiene consecuencias políticas, económicas y militares para un actor geoestratégico activo y vecino.

78 Unión Europea. Notación abreviada UE.
} 
suministros energéticos y las comunicaciones. Asuntos, considerados en la Estrategia de Seguridad Nacional de la administración Obama (de mayo 2010), cuyo objetivo general se sitúa en garantizar la seguridad y el bienestar de sus ciudadanos. Fijando entre sus intereses: la seguridad nacional y la globalización económica, la ampliación territorial de la OTAN y UE, el liderazgo de un orden internacional de paz y seguridad y la reorganización de la alianza, la independencia energética europea, el libre intercambio de bienes y servicios y, el respeto a los DDHH, los valores universales y las relaciones constructivas con otros países.

Para ello, estableció como objetivos (i) internos: favorecer el crecimiento económico y el desarrollo equilibrado y sostenible, prevenir el terrorismo, fortalecer la educación, potenciar la ciencia, tecnología e innovación, invertir sabiamente los recursos y vivir conforme los propios valores, (ii) globales: evitar el aislacionismo, construir las capacidades de socios y aliados y cooperar con otros centros de poder, derrotar el terrorismo, evitar la proliferación de armas de destrucción masiva y promover la paz y la seguridad mundiales, asegurar el ciberespacio e integrar las capacidades de la nación y, (iii) de orden internacional: fortalecer las alianzas apoyadas en valores comunes, modernizar las instituciones y los mecanismos de cooperación, participar en la ONU, el G8 y el G2079, promover la democracia, los DDHH y recurrir a la fuerza en caso de necesidad.

Todo ello, por cuanto se percibieron como amenazas el terrorismo, los conflictos post Guerra Fría y la proliferación de armas de destrucción masiva, las ciber amenazas y la dependencia energética, el cambio climático y las pandemias, los Estados fallidos y la falta de democracia, el crimen transnacional, las desigualdades y la rápida urbanización, las tensiones demográficas y culturales y la lucha por los recursos. Obvio, que dichas percepciones tienen su centro en la maximización del poder, actitud propia de la política exterior estadounidense, que no abandona el realismo y sus intenciones hegemónicas.

(iv) Reino Unido de Gran Bretaña e Irlanda del Norte

El Reino Unido dejó de ser un jugador geoestratégico, debido a su relativa caída entre poderes del viejo continente, sus contradicciones respecto a la unión y su especial relación con los Estados Unidos. Por cierto, rechazó la unificación política, no incrementó su influencia dentro de la comunidad, quiere una integración apoyada en el libre comercio y, prefiere una coordinación en política exterior, seguridad y defensa por fuera la UE. Aun así, sigue siendo un importante aliado leal, base militar y significativo socio en las actividades de inteligencia, aunque poco comprometido con la misión europea. Por cierto, su Estrategia de Seguridad Nacional (de octubre de 2010), define las amenazas a enfrentar de manera flexible y con medios apropiados, entre dichos instrumentos se encuentran la mencionada estrategia y la Revisión Estratégica de la Defensa y Seguridad (REDS), derivada de la primera y super-

\footnotetext{
${ }^{79}$ Grupo de los Veinte. Notación abreviada G20. Países miembros: Alemania, Canadá, Estados Unidos, Francia, Italia, Japón, Reino Unido y Federación de Rusia (G8), Arabia Saudita, Argentina, Australia, Brasil, China, Corea del Sur, India, Indonesia, México, Sudáfrica, Turquía y UE.
} 
visada por el Consejo de Seguridad Nacional80, que indica como equipar a sus FFAA, policías y agencias de inteligencia, situando a la seguridad nacional como el primer deber de gobierno.

Para ello, fijó a modo de objetivos prioritarios hacia el 2020, fortalecer la seguridad, acotar los riesgos sobre el país, proteger los intereses nacionales dentro y fuera del territorio, defender el imperio de la ley, la democracia, la libertad de expresión y los $\mathrm{DDHH}$, mediante la proyección de poder y preservación de las alianzas con Estados Unidos y la OTAN, integrando la UE y permaneciendo como miembro -con derecho a veto- en el Consejo de Seguridad de la ONU. Razones, por las que estableció como objetivos específicos, obtener unas FFAA mejores y más flexibles, equilibrar el presupuesto de la defensa ${ }^{81}$ y, evaluar dicha Revisión Estratégica de la Defensa y Seguridad.

Hoy por hoy, acorde lo expuesto, agrupó las amenazas en transnacionales y nacionales. Entre las externas, importan el terrorismo y los conflictos armados, el crimen organizado, la vulnerabilidad energética, la proliferación de armas de destrucción masiva, los ataques en el ciber espacio y/o el espionaje tradicional y los flujos migratorios no controlados. Sobre las internas, pesan la inseguridad económica y financiera, los desastres naturales y accidentes y, el daño a la infraestructura y los servicios críticos. Para neutralizarlas hace uso de su vinculación especial con Estados Unidos, la operatividad conjunta de sus FFAA con las de Francia, la cooperación bilateral con socios y aliados de la OTAN y UE -como Alemania, Italia, Holanda, España y Turquía- y, con aquellos que comparte intereses -como la India y Japón- o con los que está construyendo diálogos políticos y de seguridad como China, Rusia, Brasil e Indonesia. Por otra parte, juega su papel en el Consejo de Seguridad de la ONU, la OTAN, la UE, el G8, el G20 y la Commonwealth ${ }^{82}$.

Respecto a la ONU estableció como objetivos, impulsar un Consejo de Seguridad acorde a la realidad actual, consensuar disciplina presupuestaria, actuar sobre la prevención de los conflictos, realizar las reformas necesarias y trabajar hacia un ciberespacio seguro. Para con la OTAN, mantener sus compromisos e implementar el nuevo concepto estratégico, reformar la alianza (agencias, estructura de mando, de fuerzas y demás) y, buscar la cooperación entre la OTAN y la UE. Por cierto, sobre esta última apoya su expansión hacia el este, con mención de que debe respetar sus obligaciones con Turquía y los países balcánicos, a la vez que apoya las misiones -militares y/o civiles- de la unión en coincidencia con sus intereses, siempre y cuando la OTAN no esté dispuesta a intervenir.

\footnotetext{
80 Consejo de Seguridad Nacional. Órgano creado en mayo de 2010, para coordinar todos los aspectos relativos a la seguridad y optimizar recursos, como asimismo, tomar decisiones -en reuniones semanales- presididas por el primer ministro e Integradas por ministros y máximos responsables militares y de inteligencia.

81 El primer ministro anunció un recorte del $8 \%$ del presupuesto para la defensa, pero en ningún caso por debajo del $2 \%$ del PBI (porcentaje solicitado por la OTAN a sus miembros).

82 Mancomunidad Británica de Naciones. Países y administraciones miembros: Antigua y Bermuda, Australia, Bahamas, Bangladés, Barbados, Belice, Botswana, Brunei, Camerún, Canadá, Chipre, Dependencias de la Corona, Dominicana, Fiyi, Gambia, Ghana, Granada, Guyana, India, Islas Salomón, Jamaica, Kenia, Kiribati, Lesoto, Malasia, Malaui, Maldivas, Malta, Mauricio, Mozambique, Namibia, Nauru, Nigeria, Nueva Zelanda, Orden de los Compañeros de Honor, Pakistán, Papua Nueva Guinea, Reino Unido, Samoa, San Cristóbal y Nieves, San Vicente y las Granaditas, Santa Lucía, Seychelles, Sierra Leona, Singapur, Sri Lanka, Suazilandia, Sudáfrica, Tanzania, Territorios Británicos de Ultramar, Tonga, Trinidad y Tobago, Tuvalu, Uganda, Vanuatu, Venerable Orden de San Juan y, Zambia.
} 
(v) República de Polonia

Polonia representa un pivote geopolítico, que a partir de la reconciliación germano polaca ${ }^{83}$ expandió su comercio con Alemania, patrocinando los alemanes su ingreso a la OTAN, UE y triángulo de Weimar ${ }^{84}$, a la vez que una relación directa con el motor franco alemán. También, la vinculación anglo polaca facilitó las inversiones británicas, causando efectos en la relación Varsovia París por diferencias sobre el futuro europeo, el apoyo polaco a Estados Unidos en Irak, como asimismo, sobre el eje coyuntural París Berlín Moscú, ante la percepción de que Francia sacrificaría a Polonia en su entendimiento con Rusia.

Además, tiene presente a sus vecinos del este, a fin de que la unión y la alianza no se detengan en la frontera polaco ucraniana, por cuanto una Ucrania no occidental amenaza su seguridad y aspiraciones, la quiere dentro de las estructuras europea, atlántica y de Weimar. Al tiempo que revalorizó su papel en la OTAN en detrimento de Turquía, por su posición estratégica en el flanco oriental de la misma y, porque a través de ella Alemania, la UE y la OTAN, pudieron irradiar su influencia hacia los Estados Bálticos, Bielorrusia y Ucrania, que le permitió políticas de buena vecindad como las del Grupo de Visegrado85. Por otra parte, generó vínculos con Rusia debido a su cooperación en el Consejo de Estados Bálticos, siendo otro indicador, el proyecto de la dimensión este de la UE -coincidente con Estados Unidos- formado por países como los balcánicos, Bielorrusia, Moldavia y Ucrania.

Luego, para Polonia la reconciliación germano polaca, el triángulo de Weimar, la UE, la OTAN e Irak, el vínculo anglo polaco, el Grupo de Visegrado, el Consejo de Estados Bálticos y el proyecto de la dimensión este, representan hitos de su política exterior. Evidente la voluntad polaca en las políticas continental y mundial, ya que quiere influir sobre el oriente europeo y no optar entre Europa y América, de ahí su apoyo a Bielorrusia, Moldavia, Ucrania y de todo país, que reuniendo las condiciones exigidas, pueda ser parte de una gran Europa.

(vi) República de Turquía

Pivote geopolítico, con influencia sobre los mares Negro, Caspio y el Asia Central en perjuicio de Rusia y, en la medida de sus capacidades, también activo desde el punto de vista geoestratégico. Sin embargo, con problemas domésticos y limitada capacidad para movimientos regionales y proyección de poder, pero con ascendiente en Azerbaiyán y aliado sur de la OTAN, que estabiliza la región del Mar Negro, controla el paso desde y hacia el Mar Mediterráneo, contiene a los rusos en el Cáucaso y constituye una barrera contra el islamismo.

\footnotetext{
${ }^{83}$ Previo reconocimiento alemán -a mediados de los 90- de la frontera Oder-Neisse. Reconciliación de gran relevancia geopolítica en Europa Central, cuyo impacto fue similar a la reconciliación franco-alemana sobre Europa Occidental.

${ }^{84}$ Foro constituido por Alemania, Francia y Polonia, conformando un eje de 180 millones de personas de fuerte identidad nacional.

${ }^{85}$ Grupo de Visegrado. Notación abreviada V4. Países miembros: Chequia, Eslovaquia, Hungría y Polonia.
} 
Durante la post Guerra Fría, su política exterior no interfirió en los asuntos internos de los Estados centroasiáticos, fue por esos años cuando las visiones europeas y estadounidense comenzaron a diferir, para Washington un aliado entre Medio Oriente y el Asia Central, que durante la Guerra del Golfo (1991) reaccionó contra Irak, permitió bases norteamericanas en suelo propio y mantuvo el embargo de la ONU. Además, ante la cuestión kurda y el islamismo radical, asumió una política pro-Estados Unidos sobre terrorismo y seguridad.

Por cierto, los estadounidenses apoyaron su incorporación a la UE, esperando que traslade el secularismo, el sistema democrático y la economía de mercado, pero a partir de su ingreso a la misma, moderó su política en Medio Oriente y pasó su centro a la unión, aplicando el poder suave mediante la diplomacia y la economía. En este sentido, su política hacia Medio Oriente, el Asia Central y los Balcanes fue dependiente, ya que no tuvo los medios necesarios para influir por sí misma. Entonces, las opciones turcas fueron -a partir de 2003- de cooperación con Rusia y China e integración regional ${ }^{86}$ con los países árabes. Por otra parte, su orientación centroasiática ${ }^{87}$ le permitió recrear lazos con pueblos de cultura similar, apoyados en aspectos políticos, económicos, sociales y culturales en pos de hidrocarburos, teniendo en agenda siete gasoductos y dos oleoductos provenientes de Medio Oriente, Asia Central y Rusia, a favor del recurso y ganancias por el transporte a terceros e influencia regional, como asimismo, continuar con el desarrollo de su industria que requiere de nuevos mercados y fuentes de empleo.

Obviamente, fue el nexo entre oriente y occidente. Estados Unidos quiso integrar -a través de Ankara- a los nuevos países a la economía de mercado e impedir a Rusia recuperar su hegemonía, con resultados poco satisfactorios, debido a las deficiencias políticas y económicas turcas, la urgencia de los nuevos Estados, la influencia de Moscú y la competencia regional y global en Asia Centra|88. A posteriori, surgió la necesidad -en 2008- de mejorar las relaciones, que no fueron suficientes ante el ascendiente moscovita, sin embargo Kirguistán facilitó las inversiones e incorporación de tecnología industrial turca, en Kazajistán el oleoducto Bakú Tbilisi Ceyhan y el corredor de transporte Europa Cáucaso Asia (TRACECA) jugaron a favor de mejores relaciones, como asimismo, el cambio de gobierno en Turkmenistán permitió la evaluación de nuevos gasoductos ${ }^{89}$. Aun así, sus esfuerzos fueron opacados por Rusia y China, quiénes gozan de una mayor influencia.

(vii) República Federal de Alemania

Activo jugador geoestratégico, que sin dejar de lado la alianza franco alemana rivaliza con Francia, conciente de su importancia como motor económico y líder de la UE, mientras percibe su responsabilidad para con Europa

\footnotetext{
${ }^{86}$ Objetivo. Liderar la integración regional con los Estados árabes.

${ }^{87}$ Nuevas repúblicas centro asiáticas. El vacío de poder en las mismas fue simultáneo a la emergencia del nuevo gran juego.

88 Turquía en Afganistán. Bajo misión de la ONU, presidió la ISAF en Kabul -con conocimientos de la cultura local y sin enemigos concretosdurante el segundo semestre de 2002.

89 Proyecto Nabucco. Gasoductos transcaspianos.
} 
Central a la vez que representante ante Moscú. Incapaz de modificar su actual alineamiento busca la redención a través de Europa, dependiendo -para su seguridad- de la relación germano estadounidense, lo cual define su política de buen Estado y el mayor apoyo europeo de Estados Unidos.

Hasta su reunificación el liderazgo francés se apoyó en su economía, aunque modificó la política europea, ya que le permitió -con apoyo estadounidense- liderar la expansión oriental de la UE, pero sin el mismo compromiso respecto a la OTAN. Por cierto, tras la caída de la URSS -una Alemania unida- impuso a los franceses una relación de seguridad preferente con su aliado y protector transatlántico, siendo este vínculo el medio de su liderazgo. Ergo, Europa Central fue estimulada por las inversiones y el comercio alemán, motores de la inclusión -en la UE y OTANsobre la alianza franco alemana y la relación germano estadounidense.

De hecho, la zona de influencia e intereses alemanes incluye a Francia, los otrora países comunistas de Europa Central, las repúblicas Bálticas, Bielorrusia y Ucrania hasta Rusia. Además, las regiones de una preocupación especial para alemanes y franceses fijan los límites occidental y oriental europeos, mientras que el solapamiento de ambas representa la relación franco alemana como el centro vital de Europa. Indudablemente, Alemania -a partir de la reconciliación germano polaca- promovió el ingreso de Polonia en la UE y -junto a Estados Unidos- en la OTAN, afirmando el triángulo de Weimar como eje continental de unos 180 millones de personas.

\section{(viii) República Francesa}

Actor geoestratégico con una particular visión de Europa, que posee la voluntad de situar a Rusia contra Estados Unidos y Gran Bretaña contra Alemania, mientras preserva la alianza franco alemana. Un jugador con influencia sobre un gran espacio regional, por cuanto presume de ser el centro de un grupo de Estados mediterráneos y norteafricanos, mientras busca liderar la UE a favor de su otrora grandeza, pero incapaz de modificar su actual alineamiento.

Por cierto, su capacidad de veto en el Consejo de Seguridad de la ONU, su apoyo a la OTAN y el hecho de fijar una identidad política propia, le permitió cierta libertad de acción y determinado mando -en la alianza- por ser el único país europeo con armamento nuclear ${ }^{90}$ propio. Asimismo, sus pretensiones globales -entre otras- están en sus esfuerzos por la seguridad de los países francófonos africanos, que a pesar de ser una potencia media hizo suya la idea de un continente unificado. De hecho, ejerce su influencia sobre la costa norte del Mediterráneo Occidental, la península Ibérica y Alemania hacia Europa centro oriental, zona de interés político y radio mínimo de seguridad, que requiere del apoyo alemán y de los Estados del sur para liderar la UE. Obvio, que la relación franco alemana resulta difícil, ya que una Europa unida e independiente -según su óptica- sólo puede darse bajo liderazgo francés, preser-

90 Disuasión nuclear -de capacidad marginal- sobre el otrora instrumento militar soviético y actual ruso. 
vando el compromiso de Estados Unidos a la vez que disminuyendo su influencia, mientras mantiene la relación con Alemania impidiendo su liderazgo. Lo expuesto, pese a que carece de la fortaleza económica alemana y, que no puede proteger ni proyectar mucho poder fuera del continente.

Además, la reunificación germana fue una derrota para París y Moscú, razones por las que incrementó su influencia en la OTAN, regresando a ésta -en 1994- y coqueteando con Moscú y/o Londres para presionar a Estados Unidos y Alemania. Su política de preferir la maniobra en vez del disenso, reafirmó su voluntad de compensar el liderazgo estadounidense con la participación europea, quiere una Europa de mayor importancia, pesar sobre los norteamericanos a través de Rusia y recrear la vieja alianza franco británica contra el liderazgo alemán. El apoyo a la expansión de la alianza fue un hecho táctico, además de actuar como el mediador europeo ante Moscú, maniobra diplomática que le permitió equilibrar a los Estados Unidos y Alemania, presionando sobre cambios en la alianza y su organización básica. Asimismo, cuando Alemania influyó por una rápida ampliación, pidió una atención similar para el mediterráneo europeo, aumentando su capacidad negociadora -con apoyo de dicha región- cuando Polonia ingresó a la OTAN y UE. Indiscutiblemente, los franceses temen el protagonismo alemán, aun así las zonas de una preocupación especial con Alemania constituyen los límites occidental y oriental europeos, determinando el solapamiento de ambas áreas -la relación franco alemana- como el núcleo vital de Europa.

(ix) República Islámica de Irán

Irán, con un territorio de 1.800 .000 kilómetros cuadrados, más de 70 millones de habitantes y quinto productor mundial de petróleo, conforma una potencia media con intenciones de actor geoestratégico regional. Sin embargo, sus objetivos colisionan con lo inestable de su régimen islámico y su alta dependencia de la exportación de crudo. Asimismo, constituye una amenaza para sus vecinos y occidente ${ }^{91}$, ya que su programa nuclear sólo tiene supuestamente- fines pacíficos y, a pesar de ser un gran productor de petróleo tiene poca infraestructura de refinado, exportando más de 2 millones de barriles diarios e importando el $40 \%$ de su consumo de derivados, que junto al bajo precio de su energía eléctrica lo sitúan en un déficit permanente, donde el instrumento -las centrales nuclearesserían en pos de mayor energía a menor costo. Sin embargo, el secreto de su programa nuclear, su rechazo a las inspecciones regulares, el desarrollo de misiles balísticos y su agresiva retórica contra Israel y/o el apoyo a diversos grupos armados, provocaron recelos en la comunidad internacional.

A posteriori de la revolución de 1979, Irán prosiguió con su central nuclear de Busher, pero franceses y estadounidenses le negaron su apoyo. Entonces, el cambio en su relación con Rusia -a mediados de los 90- le permitió continuar, incluso con la producción de uranio enriquecido, que llevó a negociaciones con Estados Unidos y la UE y,

${ }^{91}$ Amenazas. Sobre Arabia Saudita, por sus minorías chiítas saudíes del Golfo Pérsico y Mar Rojo y, sobre Israel, un país islámico nuclear constituye una amenaza mortal. Varios científicos del programa nuclear iraní fueron muertos o heridos en territorio propio, cuya autoría Teherán- atribuye a Israel y/o EEUU. 
ante la presencia -en 2005- de fuerzas occidentales en Irak y Afganistán, tomó medidas de dispersión y protección de sus instalaciones. Ergo, factores externos e internos, cargaron sobre su programa nuclear, que pese a negociaciones prosiguió en un estado prebélico, siendo sus únicos aliados Rusia y China. Igualmente, preocupa la compra a Corea del Norte de tecnología en misiles balísticos, el apoyo a ciertos grupos armados como -a través de Siria- el libanés Hezbolláh ${ }^{92}$, las milicias chiítas ${ }^{93}$ operativas en Irak y la ayuda militar a otros grupos -siempre y cuando- actúen contra sus enemigos, como las milicias kurdas iraquíes ${ }^{94}$ y Hamas ${ }^{95}$.

También, la relación ruso iraní -en el Cáucaso- tiene intereses complementarios, pero durante la revolución islámica (1979) la actitud soviética fue de alarma y -por su probable proyección ${ }^{96}$ - entre otros, motivo de la invasión de Afganistán. Después de la muerte de Jomeini y de la guerra con Irak, moderó su discurso a favor de una política exterior de intereses nacionales, coincidiendo con Moscú ante la crisis -por Nagorno Karabaj- entre Armenia y Azerbaiyán. Aun así, rusos e iraníes fueron y son rivales y aliados por necesidad, apoyados en el comercio mutuo y en su oposición a Estados Unidos. El comercio ruso iraní -en 2010- fue de casi 4000 millones de dólares y, la participación de Gazprom y Lukoil en proyectos conjuntos de desarrollo energético, sin embargo, su programa nuclear no cuenta con el beneplácito rus $0^{97}$, de hecho Moscú se sumó a las sanciones del Consejo de Seguridad, pero retiene su apoyo con el veto ruso y chino sobre Siria -aliado de Teherán- de febrero de 2012, a modo de quitar presión sobre la región y el Asia Central.

Respecto a la relación turco iraní en el Cáucaso, sigue siendo conflictiva, uno de sus contenciosos tiene que ver con el pueblo azerí, ya que la influencia turca en Azerbaiyán llevó a rusos e iraníes a coordinar sus políticas, sobre todo cuando azeríes y turkmenos -ambos con herencia cultural persa y turca- están ante una Turquía relevante y un Irán aislado. La vinculación mejoró por el comercio y el cambio en las relaciones turco israeli ${ }^{98}$, circunstancias que llevaron a una delicada confrontación, aprovechando los iraníes el recurrente conflicto por el genocidio armenio de 1915 y, por el que Armenia y Turquía -aún hoy- tienen sus fronteras cerradas y carecen de contactos diplomáticos. Además, ambos Estados tienen importantes minorías kurdas, en Irán son -más de 4 millones- divididos en kurdos chítas y sunnitas (de mayoría en la frontera turco iraní). Asimismo, la afirmación de una entidad kurda en Irak tras la invasión de 2003- acarreó todo un problema para turcos e iraníes, sobre todo por la existencia en Turquía del Partido Kurdo de los Trabajadores (PKK) y, en Irán el Partido del Kurdistán Libre (PFLK). Por cierto, la cuestión kurda

\footnotetext{
92 Hezbolláh. Movimiento de resistencia nacional contra la ocupación israelí en los 80, esencialmente de la minoría chíta del Líbano.

${ }^{93}$ Ejército del Mahdi. Grupo armado radical -operativo en Irak- liderado por el clérigo Al Sadr. Asimismo, ya en tiempos de Saddam Hussein, grupos chítas opuestos al régimen gozaban de ayuda externa.

94 Contra el otrora régimen político de Saddam Hussein.

${ }^{95}$ Hamas. Grupo sunnita, relacionado con los hermanos musulmanes egipcios, en principio, enfrentados con los chiítas operativos en la Franja de Gaza contra Israel.

96 Probable proyección de la revolución islámica chiita hacia el Asia Central.

${ }^{97}$ Rusia desea un Irán aislado, incapaz de ser una amenaza y necesitado de ayuda externa, pero con suficientes recursos para pagarla.

98 Turquía vetó la resolución 1929 -de 2010- del Consejo de Seguridad de la ONU sobre sanciones a Irán por su programa nuclear.
} 
y su violencia asociada vincularon a Teherán y Ankara ${ }^{99}$, por cuanto los iraníes temen que -Estados Unidos e Israelaprovechen en su contra el separatismo kurdo.

A todo esto, existe la amenaza sobre el Estrecho de Ormuz, que de hecho -en la guerra Irán Irak de mediados de los 80 - los iraníes afectaron el tránsito de crudo elevando su precio y los seguros. La zona más angosta tiene 20 millas náuticas, donde iraníes y omaníes extienden su mar territorial hasta las 12 millas, teniendo los canales de aguas profundas 2 millas de ancho -uno de ingreso y otro de egreso- sobre dicha franja, separados por una zona neutral de 2 millas. Mientras el área sur del estrecho -perteneciente a Omán- está en contencioso con Irán, por cuanto los iraníes defienden líneas divisorias de base rectas, con lo que sus 12 millas podrían tener un mayor alcance. También, en la zona oeste -en el Golfo Pérsico- las aguas profundas caen dentro del mar territorial de Irán, junto a varias islas disputadas por iraníes y saudíes, respecto a dichas islas, Estados Unidos se opone a la soberanía iraní y a las líneas de base rectas, afectando a Irán y Arabia Saudita.

\section{(x) República Popular de China}

Actor geoestratégico con efectos sobre la distribución de poder en Asia, por cuanto su economía le otorga el poder material necesario, al tiempo que la caída soviética permitió la emergencia de un grupo de Estados independientes, donde China desafía a Rusia desde 1991. Ante ello, junto a Uzbekistán -el 26 de abril de 1996- fortalecieron la confianza militar, conformado -en junio de 2001- la Organización para la Cooperación de Shanghai (OCSh) ${ }^{100}$ contra el terrorismo, el separatismo y el extremismo. A los chinos les preocupa menos la política rusa en Crimea que el apoyo estadounidense a Euro Maidán, ya que -frente a escenarios de futuro como Taiwán- le conviene el desvió de la presión norteamericana sobre Rusia, atento a que fortalece su posición ante Moscú, permite su desarrollo militar y afecta intereses de Estados Unidos y sus aliados.

Obviamente, la actual crisis ucraniana redefinió fronteras, aumentó la presencia de la OTAN en Europa oriental, incrementó la tensión en conflictos congelados y precipitó las relaciones entre Rusia y Occidente. Hechos, que provocaron el polo de poder Moscú Pekín, que pese a probables fricciones a mediano y largo plazos, ambos quieren tratar los temas internacionales mediante la ONU, coordinando acciones contra un excesivo intervencionismo en los Estados soberanos, que bajo la responsabilidad de proteger no quieren repetir el escenario libio en Siria.

Por otra parte, China viene desarrollando su poder naval para seguridad de sus costas y derechos marítimos, como asimismo, para la protección de sus rutas comerciales y del transporte energético, por cuanto el desarrollo de su economía depende de la capacidad de obtener recursos de ultramar, del mercado externo y del control de

\footnotetext{
99 Irán y Turquía emitieron un comunicado conjunto para coordinar esfuerzos contra la cuestión Kurda y su violencia asociada.

100 Turquía fue aceptada como socio de diálogo y Afganistán como observador.
} 
las rutas marítimas, a efectos de asegurar el entorno estratégico de su economía de mercado. Sin duda, su paso de Estado periférico a central le permitió enfatizar la multipolaridad política internacional y las relaciones mundiales democratizadas, además de apoyar la integración económica global mediante la interdependencia de bloques regionales. Concepciones, de las que emerge su doctrina del desarrollo pacífico bajo el realismo defensivo ${ }^{101}$, buscando el control de aquellos recursos que influyen en su evolución económica, a sabiendas de que pasa por una estable y segura oferta de petróleo -a un precio razonable- y con el dominio de las rutas de transporte. Ergo, de importador de petróleo refinado pasó -en 1996- a importador de petróleo crudo, siendo el segundo consumidor mundial en 2002, con un crecimiento previsto de su consumo -entre 2002 y 2025- a una tasa media anual del $4.5 \%$ (según la EIA2005), debido a un mayor consumo que deviene de su menor dependencia del carbón, del aumento de su parque automotor y del incremento de sus reservas estratégicas, para esa fecha la dependencia del petróleo importado será del $55 \%$. Por cierto, deberá obtener la seguridad de su oferta mediante medios políticos, económicos y/o militares, por cuanto en 2003 -según datos chinos- la cantidad de petróleo importado superó los 100 millones de toneladas.

Entonces, potencia de la comunidad internacional, que debido a su actual poder económico asumió la presión de su población, la insuficiencia de sus recursos, la inseguridad en la oferta e importación de petróleo, la contención de los estadounidenses y sus aliados y las disputas con sus vecinos. Ante ello, sólo saliendo de su continente y controlando las aguas, su desarrollo -a largo plazo- puede ser posible, razones de su actual poder naval en el Mar del Sur de China y Océano Índico, para luego proyectar poder través del Océano Pacífico, por ahora bajo su doctrina del desarrollo pacífico con criterios del realismo defensivo, en protección de su soberanía, integridad territorial y evolución económica sostenible, aunque a favor -en el futuro- de una probable hegemonía.

\subsubsection{Psicología de los actores}

Sintetizada a través de dos propiedades: (i) la racionalidad, entendida como estructura de intereses que necesita -como mínimo- de un fin y un medio, donde cada actor representa una forma coherente de otorgar valores y preferencias a los objetos (reales o ideales) y, (ii) la motivación, como aquella función mediante la cual cada actor manifiesta su determinación, aversión al riesgo y empatía.

(i) Racionalidad: intereses de los actores

El interés surge cuando un actor -en un escenario- le asigna valor a un objeto, siendo los intereses objetos reales o ideales con valor para el actor, que según su estructura de valores y preferencias, clasifica jerárquicamente

\footnotetext{
${ }^{101}$ Realismo defensivo. Bajo el supuesto de que la política internacional está -apenas- por debajo de la anarquía, el objetivo del Estado sería obtener seguridad y poder, enfoque donde la seguridad representa la meta máxima de un país. Entonces, para una teoría del balance de amenazas, se necesitan cuatro variables básicas: (i) el poder agregado, como suma de todos los recursos estatales, (ii) la proximidad geográfica, (iii) el poder ofensivo, como capacidad de amenazar a otro Estado a un costo aceptable y, (iv) las percepciones del otro sobre el Estado.
} 
en fines o medios dándole un orden de importancia. De hecho, el conflicto se hizo manifiesto, cuando Rusia y los otros actores -en un cierto escenario- les atribuyeron diferentes valores a los mismos objetos.

Entonces, de una previa colección y revisión de bibliografía y/o artículos afines, fueron individualizados bajo cierta relación causal o intencional- los intereses del protagonista y de los demás actores ${ }^{102}$, expuestos para la posterior confección de la trama del conflicto -mediante planillas de identificación de intereses- como parte de la situación estratégica o representación adjudicada a Rusia.

Planillas de identificación de intereses de los actores ${ }^{103}$

Individualizados los objetos y otorgadas las variables que los caracterizan como clase (ideal o real), ámbito (político, económico o militar) y espacio (foro, mercado o territorio), se asociaron a los actores dándoles valor en términos de jerarquía (fin, medio o medio-de-cambio), orden (1, 2, $3 \ldots$..), polaridad (buena o mala), estado (actual 0 potencial) y exclusión (excluyente o no excluyente), a los efectos de exponer los intereses.

\footnotetext{
102 Intereses y actores. Premisas dialécticas de la estrategia, el paso más importante y, a la vez, el más débil de la decisión estratégica.

${ }^{103}$ Notaciones abreviadas. Federación de Rusia RU, Ucrania UA, Estados Unidos de América US, Reino Unido de Gran Bretaña e Irlanda del Norte GB, República de Polonia PL, República de Turquía TR, República Federal de Alemania DE, República Francesa FR, República Islámica de Irán IR y, República Popular de China CN.
} 
Lic. Tato Giustina

\begin{tabular}{|c|c|c|c|c|c|c|c|c|}
\hline \multirow{2}{*}{$\begin{array}{l}\text { Planilla 01. Intereses RU (prota- } \\
\text { gonista) }\end{array}$} & \multicolumn{3}{|c|}{ Objetos caracterización } & \multicolumn{5}{|c|}{ Valores clasificación } \\
\hline & Clase & Ámbito & Espacio & Jerarquía & Orden & Polaridad & Estado & Exclusión \\
\hline Contención territorial OTAN y UE. & Real & Militar & Territorio & Fin & 1 & Buena & Actual & Excluyente \\
\hline $\begin{array}{ll}\text { Adhesión territorial } & \text { República } \\
\text { Autónoma de Crimea. } & \end{array}$ & Real & Político & Territorio & Fin & 2 & Buena & Actual & Excluyente \\
\hline $\begin{array}{l}\text { Posición estratégica y proyección } \\
\text { naval sobre y desde Mar Negro. }\end{array}$ & Real & Militar & Territorio & Fin & 3 & Buena & Actual & Excluyente \\
\hline $\begin{array}{l}\text { Unidad paneslavista c/ población } \\
\text { rusa y/o pro-rusa de Crimea. }\end{array}$ & Real & Militar & Territorio & Fin & 4 & Buena & Actual & Excluyente \\
\hline Unidad estratégica euroasiática. & Ideal & Político & Foro & Fin & 5 & Buena & Pot. & Excluyente \\
\hline $\begin{array}{l}\text { Alianza c/ grupos de autodefensa } \\
\text { crimeos. }\end{array}$ & Real & Militar & Territorio & Medio & 6 & Buena & Actual & Excluyente \\
\hline $\begin{array}{l}\text { Total incorporación ucraniana en } \\
\text { la CEI. }\end{array}$ & Ideal & Político & Foro & Medio & 7 & Buena & Pot. & Excluyente \\
\hline $\begin{array}{l}\text { Imagen e influencia para liderazgo } \\
\text { en asuntos globales s/ ex repúbli- } \\
\text { cas soviéticas. }\end{array}$ & Ideal & Político & Foro & Medio & 8 & Buena & Pot. & Excluyente \\
\hline Comercio libre en la CEI. & Real & Econ. & Mercado & Medio & 9 & Buena & Actual & $\begin{array}{l}\text { No exclu- } \\
\text { yente }\end{array}$ \\
\hline $\begin{array}{l}\text { Resolución de organismos inter- } \\
\text { nacionales s/ ilegitimidad gobierno } \\
\text { ucraniano. }\end{array}$ & Ideal & Político & Foro & Medio & 10 & Buena & Pot. & $\begin{array}{l}\text { No exclu- } \\
\text { yente }\end{array}$ \\
\hline $\begin{array}{l}\text { Asistencia económica financiera } \mathrm{p} / \\
\text { Ucrania. }\end{array}$ & Real & Econ. & Mercado & Medio & 11 & Buena & Pot. & $\begin{array}{l}\text { No exclu- } \\
\text { yente }\end{array}$ \\
\hline
\end{tabular}

\begin{tabular}{|c|c|c|c|c|c|c|c|c|}
\hline \multirow[t]{2}{*}{ Planilla 02. Intereses UA } & \multicolumn{3}{|c|}{ Objetos caracterización } & \multicolumn{5}{|c|}{ Valores clasificación } \\
\hline & Clase & Ámbito & Espacio & Jerarquía & Orden & Polaridad & Estado & Exclusión \\
\hline Integridad territorial. & Ideal & Político & Territorio & Fin & 1 & Buena & Pot. & Excluyente \\
\hline Soberanía estatal. & Ideal & Político & Territorio & Fin & 2 & Buena & Pot. & Excluyente \\
\hline $\begin{array}{l}\text { Negociación para la incorporación } \\
\text { en UE y OTAN. }\end{array}$ & Ideal & Político & Foro & Fin & 3 & Buena & Pot. & $\begin{array}{l}\text { No exclu- } \\
\text { yente }\end{array}$ \\
\hline $\begin{array}{l}\text { Unidad nacional cl diversidad } \\
\text { política y poblacional. }\end{array}$ & Ideal & Político & Territorio & Fin & 4 & Buena & Pot. & Excluyente \\
\hline Independencia energética. & Ideal & Econ. & Mercado & Fin & 5 & Buena & Pot. & Excluyente \\
\hline $\begin{array}{l}\text { Retiro fuerzas rusas y desarme de } \\
\text { autodefensas pro-rusas. }\end{array}$ & Real & Militar & Territorio & Medio & 6 & Buena & Pot. & Excluyente \\
\hline $\begin{array}{l}\text { Ayuda internacional ante fuerzas } \\
\text { rusas de ocupación. }\end{array}$ & Real & Político & Foro & Medio & 7 & Buena & Actual & $\begin{array}{l}\text { No exclu- } \\
\text { yente }\end{array}$ \\
\hline $\begin{array}{l}\text { Negociación por energéticos y } \\
\text { tránsito de energéticos rusos. }\end{array}$ & Real & Econ. & Mercado & Medio & 8 & Buena & Actual & Excluyente \\
\hline $\begin{array}{l}\text { Política activa de liderazgo de una } \\
\text { CEl sólo económica y comercial. }\end{array}$ & Ideal & Político & Foro & Medio & 9 & Buena & Pot. & Excluyente \\
\hline $\begin{array}{l}\text { Resolución de organismos inter- } \\
\text { nacionales contra anexión de } \\
\text { Crimea. }\end{array}$ & Real & Político & Foro & Medio & 10 & Buena & Actual & $\begin{array}{l}\text { No exclu- } \\
\text { yente }\end{array}$ \\
\hline $\begin{array}{l}\text { Obtención asistencia económica } \\
\text { financiera internacional e inversio- } \\
\text { nes extranjeras directas. }\end{array}$ & Ideal & Econ. & Mercado & Medio & 11 & Buena & Pot. & $\begin{array}{l}\text { No exclu- } \\
\text { yente }\end{array}$ \\
\hline
\end{tabular}


Lic. Tato Giustina

\begin{tabular}{|l|c|c|c|c|c|c|c|c|}
\hline Planilla 03. Intereses US & \multicolumn{2}{|c|}{ Objetos caracterización } & \multicolumn{5}{|c|}{ Valores clasificación } \\
\cline { 2 - 10 } & Clase & Ámbito & Espacio & Jerarquía & Orden & Polaridad & Estado & Exclusión \\
\hline Seguridad nacional. & Ideal & Político & Territorio & Fin & 1 & Buena & Actual & Excluyente \\
\hline Globalización de la economía. & Real & Econ. & Mercado & Fin & 2 & Buena & Actual & $\begin{array}{c}\text { No exclu- } \\
\text { yente }\end{array}$ \\
\hline $\begin{array}{l}\text { Ampliación territorial de la UE y } \\
\text { OTAN. }\end{array}$ & Real & Político & Territorio & Fin & 3 & Buena & Actual & $\begin{array}{c}\text { No exclu- } \\
\text { yente }\end{array}$ \\
\hline $\begin{array}{l}\text { Negociación para la incorporación } \\
\text { ucraniana en UE y OTAN. }\end{array}$ & Ideal & Político & Territorio & Fin & 4 & Buena & Pot. & $\begin{array}{c}\text { No exclu- } \\
\text { yente }\end{array}$ \\
\hline $\begin{array}{l}\text { Liderazgo de un orden internacio- } \\
\text { nal de paz y seguridad. }\end{array}$ & Ideal & Político & Foro & Fin & 5 & Buena & Pot. & Excluyente \\
\hline $\begin{array}{l}\text { Reorganización de la OTAN. } \\
\text { Real }\end{array}$ & Político & Foro & Medio & 6 & Buena & Pot. & Excluyente \\
\hline $\begin{array}{l}\text { Independencia energética UE. } \\
\text { Asistencia económica y financiera } \\
\text { internacional e inversiones direc- } \\
\text { tas a Ucrania. }\end{array}$ & Ideal & Econ. & Mercado & Medio & 7 & Buena & Pot. & Excluyente \\
\hline $\begin{array}{l}\text { Influencia global. } \\
\text { Intercambio libre de bienes y } \\
\text { servicios. }\end{array}$ & Ideal & Político & Territorio & Medio & 9 & Buena & Pot. & $\begin{array}{c}\text { No exclu- } \\
\text { yente }\end{array}$ \\
\hline $\begin{array}{l}\text { Respeto a DDHH, valores univer- } \\
\text { sales y relaciones constructivas } \\
\text { con otros Estados. }\end{array}$ & Econ. & Mercado & Medio & 10 & Buena & Pot. & $\begin{array}{l}\text { No exclu- } \\
\text { yente }\end{array}$ \\
\hline
\end{tabular}

\begin{tabular}{|c|c|c|c|c|c|c|c|c|}
\hline \multirow{2}{*}{ Planilla 04. Intereses GB } & \multicolumn{3}{|c|}{ Objetos caracterización } & \multicolumn{5}{|c|}{ Valores clasificación } \\
\hline & Clase & Ámbito & Espacio & Jerarquía & Orden & Polaridad & Estado & Exclusión \\
\hline Seguridad nacional. & Ideal & Político & Territorio & Fin & 1 & Buena & Actual & Excluyente \\
\hline $\begin{array}{l}\text { Globalización económica con uso } \\
\text { óptimo de recursos. }\end{array}$ & Ideal & Econ. & Mercado & Fin & 2 & Buena & Pot. & $\begin{array}{l}\text { No exclu- } \\
\text { yente }\end{array}$ \\
\hline Seguridad colectiva. & Ideal & Político & Foro & Fin & 3 & Buena & Pot. & $\begin{array}{l}\text { No exclu- } \\
\text { yente }\end{array}$ \\
\hline $\begin{array}{l}\text { Ampliación territorial de la UE y } \\
\text { OTAN. }\end{array}$ & Real & Político & Territorio & Fin & 4 & Buena & Actual & $\begin{array}{l}\text { No exclu- } \\
\text { yente }\end{array}$ \\
\hline $\begin{array}{l}\text { Pactos externos en seguridad y } \\
\text { defensa coincidentes } \mathrm{c} / \text { intereses } \\
\text { nacionales. }\end{array}$ & Ideal & Político & Foro & Fin & 5 & Buena & Pot. & Excluyente \\
\hline $\begin{array}{l}\text { Concepto estratégico nuevo y } \\
\text { reorganización de la OTAN. }\end{array}$ & Real & Militar & Foro & Medio & 6 & Buena & Pot. & Excluyente \\
\hline $\begin{array}{l}\text { Coordinación por fuera UE asun- } \\
\text { tos exteriores, seguridad y defen- } \\
\text { sa. }\end{array}$ & Ideal & Político & Foro & Medio & 7 & Buena & Pot. & $\begin{array}{l}\text { No exclu- } \\
\text { yente }\end{array}$ \\
\hline $\begin{array}{l}\text { Presencia en ONU, OTAN, UE, } \\
\text { G8, G20 y Commonwealth. }\end{array}$ & Real & Político & Foro & Medio & 8 & Buena & Actual & $\begin{array}{l}\text { No exclu- } \\
\text { yente }\end{array}$ \\
\hline $\begin{array}{l}\text { Prevención de conflictos y coordi- } \\
\text { nación ONU, OTAN y UE. }\end{array}$ & Ideal & Político & Foro & Medio & 9 & Buena & Pot. & $\begin{array}{l}\text { No exclu- } \\
\text { yente }\end{array}$ \\
\hline Ciberespacio seguro. & Ideal & Militar & Foro & Medio & 10 & Buena & Pot. & Excluyente \\
\hline $\begin{array}{l}\text { Integración económica de libre } \\
\text { comercio. }\end{array}$ & Ideal & Econ. & Mercado & Medio & 11 & Buena & Pot. & $\begin{array}{l}\text { No exclu- } \\
\text { yente }\end{array}$ \\
\hline
\end{tabular}


Lic. Tato Giustina

\begin{tabular}{|l|c|c|c|c|c|c|c|c|}
\hline Planilla 05. Intereses PL & \multicolumn{2}{|c|}{ Objetos caracterización } & \multicolumn{5}{|c|}{ Valores clasificación } \\
\cline { 2 - 10 } & Clase & Ámbito & Espacio & Jerarquía & Orden & Polaridad & Estado & Exclusión \\
\hline Seguridad nacional. & Ideal & Político & Territorio & Fin & 1 & Buena & Actual & Excluyente \\
\hline $\begin{array}{l}\text { Desarrollo económico con UE e } \\
\text { inversiones extranjeras directas. }\end{array}$ & Real & Econ. & Mercado & Fin & 2 & Buena & Actual & $\begin{array}{c}\text { No exclu- } \\
\text { yente }\end{array}$ \\
\hline $\begin{array}{l}\text { Logro de la incorporación ucrania- } \\
\text { na a la UE, OTAN y triángulo de } \\
\text { Weimar. }\end{array}$ & Ideal & Político & Foro & Fin & 3 & Buena & Pot. & Excluyente \\
\hline $\begin{array}{l}\text { Posición de influencia sobre Euro- } \\
\text { pa Central y Oriental. }\end{array}$ & Ideal & Político & Territorio & Fin & 4 & Buena & Actual & $\begin{array}{l}\text { No exclu- } \\
\text { yente }\end{array}$ \\
\hline $\begin{array}{l}\text { Ampliación territorial de la UE y } \\
\text { OTAN. }\end{array}$ & Real & Político & Territorio & Fin & 5 & Buena & Actual & $\begin{array}{l}\text { No exclu- } \\
\text { yente }\end{array}$ \\
\hline $\begin{array}{l}\text { Pactos con OTAN, UE y países } \\
\text { aliados y socios. }\end{array}$ & Real & Político & Foro & Medio & 6 & Buena & Actual & Excluyente \\
\hline $\begin{array}{l}\text { Presencia en triángulo de Weimar, } \\
\text { UE, OTAN, Grupo de Visegrado y } \\
\text { Consejo de Estados Bálticos. }\end{array}$ & Real & Político & Foro & Medio & 7 & Buena & Actual & $\begin{array}{c}\text { No exclu- } \\
\text { yente }\end{array}$ \\
\hline $\begin{array}{l}\text { Independencia energética. } \\
\text { Relaciones exteriores de buen } \\
\text { vecino. }\end{array}$ & Ideal & Econ. & Mercado & Medio & 8 & Buena & Pot. & Excluyente \\
\hline $\begin{array}{l}\text { Formación universo económico } \\
\text { común europeo. }\end{array}$ & Ideal & Político & Foro & Medio & 9 & Buena & Actual & $\begin{array}{l}\text { No exclu- } \\
\text { yente }\end{array}$ \\
\hline $\begin{array}{l}\text { Auxilio económico financiero a } \\
\text { países europeos no integrantes de } \\
\text { la UE. }\end{array}$ & Ideal & Econ. & Mercado & Medio & 10 & Buena & Pot. & $\begin{array}{l}\text { No exclu- } \\
\text { yente }\end{array}$ \\
\hline
\end{tabular}

\begin{tabular}{|c|c|c|c|c|c|c|c|c|}
\hline \multirow{2}{*}{ Planilla 06. Intereses TR } & \multicolumn{3}{|c|}{ Objetos caracterización } & \multicolumn{5}{|c|}{ Valores clasificación } \\
\hline & Clase & Ámbito & Espacio & Jerarquía & Orden & Polaridad & Estado & Exclusión \\
\hline Seguridad nacional. & Ideal & Político & Territorio & Fin & 1 & Buena & Actual & Excluyente \\
\hline $\begin{array}{l}\text { Desarrollo del comercio y nuevas } \\
\text { fuentes de empleo c/ UE y Asia } \\
\text { Central. }\end{array}$ & Ideal & Econ. & Mercado & Fin & 2 & Buena & Pot. & $\begin{array}{l}\text { No exclu- } \\
\text { yente }\end{array}$ \\
\hline $\begin{array}{l}\text { Desarrollo de influencias p/ cons- } \\
\text { trucción conjunta infraestructura } \\
\text { transporte de energéticos c/ Rusia, } \\
\text { Asia Central y Medio Oriente. }\end{array}$ & Ideal & Econ. & Mercado & Fin & 3 & Buena & Pot. & $\begin{array}{l}\text { No exclu- } \\
\text { yente }\end{array}$ \\
\hline $\begin{array}{l}\text { Ampliación territorial de la UE y } \\
\text { OTAN. }\end{array}$ & Real & Político & Territorio & Fin & 4 & Buena & Actual & $\begin{array}{l}\text { No exclu- } \\
\text { yente }\end{array}$ \\
\hline Liderazgo en integración regional. & Ideal & Econ. & Mercado & Fin & 5 & Buena & Pot. & Excluyente \\
\hline $\begin{array}{l}\text { Posición de influencia s/ los Bal- } \\
\text { canes, Cáucaso y Asia Central. }\end{array}$ & Ideal & Político & Territorio & Medio & 6 & Buena & Actual & $\begin{array}{l}\text { No exclu- } \\
\text { yente }\end{array}$ \\
\hline $\begin{array}{l}\text { Contención regional del poder } \\
\text { ruso e iraní. }\end{array}$ & Ideal & Político & Territorio & Medio & 7 & Buena & Actual & Excluyente \\
\hline $\begin{array}{l}\text { Presencia estratégica s/ Medite- } \\
\text { rráneo Oriental, Mar Negro y Mar } \\
\text { Caspio. }\end{array}$ & Real & Militar & Territorio & Medio & 8 & Buena & Actual & $\begin{array}{c}\text { No exclu- } \\
\text { yente }\end{array}$ \\
\hline $\begin{array}{l}\text { Actitud activa en contraterrorismo } \\
\text { y contrainsurgencia. }\end{array}$ & Ideal & Militar & Territorio & Medio & 9 & Buena & Actual & Excluyente \\
\hline $\begin{array}{l}\text { Presencia internacional c/ capital y } \\
\text { bienes industriales. }\end{array}$ & Real & Econ. & Mercado & Medio & 10 & Buena & Actual & $\begin{array}{l}\text { No exclu- } \\
\text { yente }\end{array}$ \\
\hline $\begin{array}{l}\text { Actitud activa en satisfacción } \\
\text { transporte y demanda energéticos. }\end{array}$ & Ideal & Econ. & Mercado & Medio & 11 & Buena & Pot. & $\begin{array}{c}\text { No exclu- } \\
\text { yente }\end{array}$ \\
\hline
\end{tabular}




\begin{tabular}{|c|c|c|c|c|c|c|c|c|}
\hline \multirow[t]{2}{*}{ Planilla 07. Intereses DE } & \multicolumn{3}{|c|}{ Objetos caracterización } & \multicolumn{5}{|c|}{ Valores clasificación } \\
\hline & Clase & Ámbito & Espacio & Jerarquía & Orden & Polaridad & Estado & Exclusión \\
\hline Seguridad nacional. & Ideal & Político & Territorio & Fin & 1 & Buena & Actual & Excluyente \\
\hline Desarrollo económico con UE. & Real & Econ. & Mercado & Fin & 2 & Buena & Actual & $\begin{array}{l}\text { No exclu- } \\
\text { yente }\end{array}$ \\
\hline $\begin{array}{l}\text { Ampliación territorial de la UE y } \\
\text { OTAN. }\end{array}$ & Real & Político & Territorio & Fin & 3 & Buena & Actual & $\begin{array}{l}\text { No exclu- } \\
\text { yente }\end{array}$ \\
\hline $\begin{array}{l}\text { Obtención del ingreso ucraniano a la } \\
\text { UE y OTAN. }\end{array}$ & Ideal & Político & Foro & Fin & 4 & Buena & Pot. & Excluyente \\
\hline Liderazgo de la UE. & Ideal & Político & Foro & Fin & 5 & Buena & Actual & Excluyente \\
\hline $\begin{array}{l}\text { Pactos c/ EEUU, OTAN, UE y países } \\
\text { aliados y socios. }\end{array}$ & Real & Político & Foro & Medio & 6 & Buena & Actual & Excluyente \\
\hline $\begin{array}{l}\text { Presencia activa s/ triángulo de Wei- } \\
\text { mar, UE y OTAN. }\end{array}$ & Real & Político & Foro & Medio & 7 & Buena & Actual & $\begin{array}{l}\text { No exclu- } \\
\text { yente }\end{array}$ \\
\hline Cooperación transnacional europea. & Ideal & Político & Foro & Medio & 8 & Buena & Pot. & $\begin{array}{l}\text { No exclu- } \\
\text { yente }\end{array}$ \\
\hline $\begin{array}{l}\text { Inversiones y comercio libre c/ Euro- } \\
\text { pa Central, Estados Bálticos, Ucrania } \\
\text { y Bielorrusia. }\end{array}$ & Real & Econ. & Mercado & Medio & 9 & Buena & Actual & $\begin{array}{l}\text { No exclu- } \\
\text { yente }\end{array}$ \\
\hline Política positiva de buen vecino. & Real & Político & Foro & Medio & 10 & Buena & Actual & $\begin{array}{l}\text { No exclu- } \\
\text { yente }\end{array}$ \\
\hline $\begin{array}{l}\text { Política activa de influencias s/ Euro- } \\
\text { pa Central, Estados Bálticos, Ucra- } \\
\text { nia, Bielorrusia y Rusia. }\end{array}$ & Ideal & Político & Territorio & Medio & 11 & Buena & Actual & $\begin{array}{l}\text { No exclu- } \\
\text { yente }\end{array}$ \\
\hline
\end{tabular}

\begin{tabular}{|c|c|c|c|c|c|c|c|c|}
\hline \multirow[t]{2}{*}{ Planilla 08. Intereses FR } & \multicolumn{3}{|c|}{ Objetos caracterización } & \multicolumn{5}{|c|}{ Valores clasificación } \\
\hline & Clase & Ámbito & Espacio & Jerarquía & Orden & Polaridad & Estado & Exclusión \\
\hline Seguridad nacional. & Ideal & Político & Territorio & Fin & 1 & Buena & Actual & Excluyente \\
\hline Disuasión nuclear. & Ideal & Militar & Territorio & Fin & 2 & Buena & Actual & Excluyente \\
\hline Pacto seguridad EEUU - UE. & Real & Militar & Territorio & Fin & 3 & Buena & Actual & Excluyente \\
\hline $\begin{array}{l}\text { Ampliación territorial de la UE y } \\
\text { OTAN. }\end{array}$ & Real & Político & Territorio & Fin & 4 & Buena & Actual & $\begin{array}{l}\text { No exclu- } \\
\text { yente }\end{array}$ \\
\hline $\begin{array}{l}\text { Liderazgo UE e influencia en su } \\
\text { expansión. }\end{array}$ & Ideal & Político & Foro & Fin & 5 & Buena & Pot. & Excluyente \\
\hline $\begin{array}{l}\text { Presencia activa s/ triángulo de } \\
\text { Weimar, UE, OTAN, ONU y países } \\
\text { francófonos africanos. }\end{array}$ & Real & Político & Foro & Medio & 6 & Buena & Actual & $\begin{array}{l}\text { No exclu- } \\
\text { yente }\end{array}$ \\
\hline $\begin{array}{l}\text { Pactos c/ OTAN, UE y países aliados } \\
\text { y socios. }\end{array}$ & Real & Político & Foro & Medio & 7 & Buena & Actual & Excluyente \\
\hline $\begin{array}{l}\text { Operaciones militares conjuntas con } \\
\text { RU. }\end{array}$ & Real & Militar & Territorio & Medio & 8 & Buena & Actual & Excluyente \\
\hline $\begin{array}{l}\text { Relevancia UE en la reorganización } \\
\text { de la OTAN. }\end{array}$ & Ideal & Político & Foro & Medio & 9 & Buena & Pot. & Excluyente \\
\hline $\begin{array}{l}\text { Posición de influencia s/ países } \\
\text { europeos mediterráneo occidentales. }\end{array}$ & Ideal & Político & Territorio & Medio & 10 & Buena & Actual & $\begin{array}{l}\text { No exclu- } \\
\text { yente }\end{array}$ \\
\hline Mediación UE - Rusia. & Ideal & Político & Foro & Medio & 11 & Buena & Pot. & Excluyente \\
\hline
\end{tabular}


Lic. Tato Giustina

\begin{tabular}{|c|c|c|c|c|c|c|c|c|}
\hline \multirow[t]{2}{*}{ Planilla 09. Intereses IR } & \multicolumn{3}{|c|}{ Objetos caracterización } & \multicolumn{5}{|c|}{ Valores clasificación } \\
\hline & Clase & Ámbito & Espacio & Jerarquía & Orden & Polaridad & Estado & Exclusión \\
\hline Seguridad Nacional. & Ideal & Político & Territorio & Fin & 1 & Buena & Actual & Excluyente \\
\hline Desarrollo programa nuclear. & Real & Político & Territorio & Fin & 2 & Buena & Actual & Excluyente \\
\hline $\begin{array}{l}\text { Relaciones exteriores de intereses } \\
\text { nacionales. }\end{array}$ & Ideal & Político & Foro & Fin & 3 & Buena & Actual & $\begin{array}{l}\text { No exclu- } \\
\text { yente }\end{array}$ \\
\hline Desarrollo económico sustentable. & Ideal & Econ. & Mercado & Fin & 4 & Buena & Pot. & $\begin{array}{l}\text { No exclu- } \\
\text { yente }\end{array}$ \\
\hline $\begin{array}{l}\text { Posición de Influencia s/ Cáucaso, } \\
\text { Asia Central y Medio Oriente. }\end{array}$ & Ideal & Político & Territorio & Fin & 5 & Buena & Actual & $\begin{array}{l}\text { No exclu- } \\
\text { yente }\end{array}$ \\
\hline $\begin{array}{l}\text { Disuasión nuclear s/ fuerzas occi- } \\
\text { dentales y contención de grupos } \\
\text { étnicos y/o religiosos. }\end{array}$ & Real & Militar & Territorio & Medio & 6 & Buena & Actual & Excluyente \\
\hline Desarrollo de misiles balísticos. & Real & Militar & Territorio & Medio & 7 & Buena & Actual & Excluyente \\
\hline $\begin{array}{l}\text { Pactos con Rusia, Corea del Norte, } \\
\text { Siria y Armenia. }\end{array}$ & Real & Político & Territorio & Medio & 8 & Buena & Actual & Excluyente \\
\hline $\begin{array}{l}\text { Acciones } \mathrm{p} / \text { comercialización de } \\
\text { crudo y proyección } \mathrm{p} / \text { infraestructura } \\
\text { propia refinado de petróleo. }\end{array}$ & Ideal & Econ. & Mercado & Medio & 9 & Buena & Pot. & Excluyente \\
\hline $\begin{array}{l}\text { Comercio ruso iraní cl proyectos } \\
\text { energéticos conjuntos y turco iraní s/ } \\
\text { energéticos. }\end{array}$ & Real & Econ. & Mercado & Medio & 10 & Buena & Actual & $\begin{array}{l}\text { No exclu- } \\
\text { yente }\end{array}$ \\
\hline $\begin{array}{l}\text { Negociaciones s/ programa nuclear y } \\
\text { posición en Estrecho de Ormuz cl } \\
\text { UE, EEUU y ONU. }\end{array}$ & Real & Político & Foro & Medio & 11 & Buena & Actual & $\begin{array}{l}\text { No exclu- } \\
\text { yente }\end{array}$ \\
\hline
\end{tabular}

\begin{tabular}{|c|c|c|c|c|c|c|c|c|}
\hline \multirow[t]{2}{*}{ Planilla 10. Intereses CN } & \multicolumn{3}{|c|}{ Objetos caracterización } & \multicolumn{5}{|c|}{ Valores clasificación } \\
\hline & Clase & Ámbito & Espacio & Jerarquía & Orden & Polaridad & Estado & Exclusión \\
\hline Seguridad nacional. & Ideal & Político & Territorio & Fin & 1 & Buena & Actual & Excluyente \\
\hline $\begin{array}{l}\text { Soberanía e integridad s/ territorio } \\
\text { continental y marítimo. }\end{array}$ & Ideal & Político & Territorio & Fin & 2 & Buena & Actual & Excluyente \\
\hline $\begin{array}{l}\text { Posición de influencia s/ Asia Cen- } \\
\text { tral, Mar del Sur de China y Océano } \\
\text { Indico. }\end{array}$ & Ideal & Político & Territorio & Fin & 3 & Buena & Actual & $\begin{array}{l}\text { No exclu- } \\
\text { yente }\end{array}$ \\
\hline $\begin{array}{l}\text { Doctrina desarrollo pacífico bajo } \\
\text { realismo defensivo y espacios co- } \\
\text { munes de coexistencia. }\end{array}$ & Ideal & Político & Foro & Fin & 4 & Buena & Actual & Excluyente \\
\hline $\begin{array}{l}\text { Desarrollo económico sostenible a } \\
\text { largo plazo. }\end{array}$ & Ideal & Econ. & Mercado & Fin & 5 & Buena & Pot. & $\begin{array}{l}\text { No exclu- } \\
\text { yente }\end{array}$ \\
\hline $\begin{array}{l}\text { Obtención oferta estable y segura de } \\
\text { energéticos } \mathrm{c} \text { control rutas de trans- } \\
\text { porte. }\end{array}$ & Ideal & Militar & Territorio & Medio & 6 & Buena & Pot. & Excluyente \\
\hline Desarrollo industria naval militar. & Real & Militar & Territorio & Medio & 7 & Buena & Actual & Excluyente \\
\hline $\begin{array}{l}\text { Contención de UE, EEUU y países } \\
\text { aliados y socios. }\end{array}$ & Real & Político & Territorio & Medio & 8 & Buena & Actual & Excluyente \\
\hline $\begin{array}{l}\text { Seguridad regional por Organización } \\
\text { Cooperación de Shanghai. }\end{array}$ & Real & Político & Foro & Medio & 9 & Buena & Actual & Excluyente \\
\hline $\begin{array}{l}\text { Integración económica global por } \\
\text { bloques económicos regionales. }\end{array}$ & Real & Econ. & Mercado & Medio & 10 & Buena & Actual & $\begin{array}{l}\text { No exclu- } \\
\text { yente }\end{array}$ \\
\hline Asuntos internacionales por ONU. & Real & Político & Foro & Medio & 11 & Buena & Actual & $\begin{array}{l}\text { No exclu- } \\
\text { yente }\end{array}$ \\
\hline
\end{tabular}


(ii) Motivación de los actores

La motivación resulta importante en el proceso de toma de decisiones, por cuanto permite relacionar determinación, aversión al riesgo y empatía (comunicatividad), transitando desde los competitivos halcones a los cooperativos palomos como forma de vincularse a otros actores en un mismo escenario. Por supuesto, Rusia conociendo la motivaciones de los otros actores acotó su incertidumbre, lo que le permitió escalar o desescalar, siendo relevante su proceder ante aliados y opuestos durante la conducción del conflicto.

Acorde lo expuesto, las diferentes motivaciones tienen presente las variables determinación, aversión al riesgo y empatía, graduadas mediante una de las dos constantes -alta o baja- $y$, comenzando con el benigno palomo de baja determinación, alta aversión al riesgo y alta empatía, para caminar hacia el agresivo halcón de alta determinación, baja aversión al riesgo y baja empatía.

Cuadro I. Motivación de los actores

\begin{tabular}{|l|c|c|c|c|}
\hline \multicolumn{1}{|c|}{ Actor } & Determinación & Aversión al riesgo & Empatía & Carácter \\
\hline F. de Rusia (prot.) & Alta & Baja & Alta & Halcón \\
\hline Ucrania & Baja & Alta & Alta & Palomo \\
\hline E. U. de América & Alta & Baja & Alta & Halcón \\
\hline R. F. de Alemania & Baja & Alta & Alta & Palomo \\
\hline R. Francesa & Baja & Alta & Alta & Palomo \\
\hline R. Unido & Baja & Alta & Alta & Palomo \\
\hline R. de Polonia & Baja & Alta & Alta & Palomo \\
\hline R. de Turquía & Alta & Baja & Baja & Halcón \\
\hline R. I. de Irán & Alta & Baja & Baja & Halcón \\
\hline R. P. de China & Alta & Baja & Baja & Halcón \\
\hline
\end{tabular}

\subsubsection{Trama del conflicto}

La trama del conflicto presenta el número de vinculaciones entre los actores, propia de considerar sus intereses entre sí, que constituye una abstracción a favor de la comprensión del conflicto como dialéctica de voluntades. Para su desarrollo se agrupó a los actores en parejas (relación binaria) y, (i) se consideraron los fines relacionados por causalidad o intencionalidad, (ii) se determinó la coincidencia o discrepancia entre fines iguales o dependientes basados en su polaridad y exclusión y, (iii) se estimó la cooperación o competencia entre actores, apreciando las relaciones de coincidencia o discrepancia entre fines según su orden de importancia. Entonces, entre dos actores cuyos fines coincidentes fueron más cuantiosos que los discrepantes, conformaron una relación de cooperación, caso contrario de competencia. 
Planilla 11. Relaciones de intereses Federación de Rusia - Ucrania

\begin{tabular}{|c|c|c|}
\hline Federación de Rusia (protagonista) & Relación & Ucrania \\
\hline F1. Contención territorial OTAN y UE. & & F1. Integridad territorial. \\
\hline $\begin{array}{l}\text { F2. Adhesión territorial República } A \mathrm{~L} \\
\text { noma de Crimea. }\end{array}$ & & F2. Soberanía estatal. \\
\hline $\begin{array}{l}\text { F3. Posición estratégica y proyec } \\
\text { naval sobre y desde Mar Negro. }\end{array}$ & & $\begin{array}{l}\text { F3. Negociación para la incorporación en } \\
\text { UE y OTAN. }\end{array}$ \\
\hline $\begin{array}{l}\text { F4. Unidad paneslavista c/ pobla } \\
\text { rusa y/o pro-rusa de Crimea. }\end{array}$ & & $\begin{array}{l}\text { 4. Unidad nacional c/ diversidad política } \\
\text { y poblacional. }\end{array}$ \\
\hline F5. Unidad estratégica euroasiática. & & F5. Independencia energética. \\
\hline $\begin{array}{l}\text { M6. Alianza cl grupos de autodefens } \\
\text { crimeos. }\end{array}$ & & $\begin{array}{l}\text { M6. Retiro fuerzas rusas y desarme de } \\
\text { autodefensas pro-rusas. }\end{array}$ \\
\hline $\begin{array}{l}\text { M7. Total incorporación ucraniana en la } \\
\text { CEl. }\end{array}$ & & $\begin{array}{l}\text { M7. Ayuda internacional ante fuerzas } \\
\text { tusas de ocupación. }\end{array}$ \\
\hline $\begin{array}{l}\text { M8. Imagen e influencia para liderazg } \\
\text { en asuntos globales sobre ex república } \\
\text { soviéticas. }\end{array}$ & & $\begin{array}{l}\text { M8. Negociación por energéticos y trán- } \\
\text { sito de energéticos rusos. }\end{array}$ \\
\hline M9. Comercio libre en la CEI. & & $\begin{array}{l}\text { M9. Política activa de liderazgo de una } \\
\text { CEl sólo económica y comercial. }\end{array}$ \\
\hline $\begin{array}{l}\text { M10. Resolución de organismos interna } \\
\text { cionales s/ ilegitimidad gobierno ucra } \\
\text { niano. }\end{array}$ & & $\begin{array}{l}\text { M10. Resolución de organismos interna- } \\
\text { cionales contra anexión de Crimea. }\end{array}$ \\
\hline $\begin{array}{l}\text { M11. Asistencia económica financiera } p \\
\text { Ucrania. }\end{array}$ & & $\begin{array}{l}\text { M11. Obtención asistencia económica } \\
\text { financiera internacional e inversiones } \\
\text { extranjeras directas. }\end{array}$ \\
\hline
\end{tabular}

IDENTIFICACIÓN: fines con fines.

PODER: medios a fines.

FUERZA: medios de cambio a medios de cambio. Relación cuantitativa.
Cooperación

Competencia

$\mathrm{Fp} / \mathrm{Fa}$ 
Planilla 12. Relaciones de intereses Federación de Rusia - Estados Unidos de América

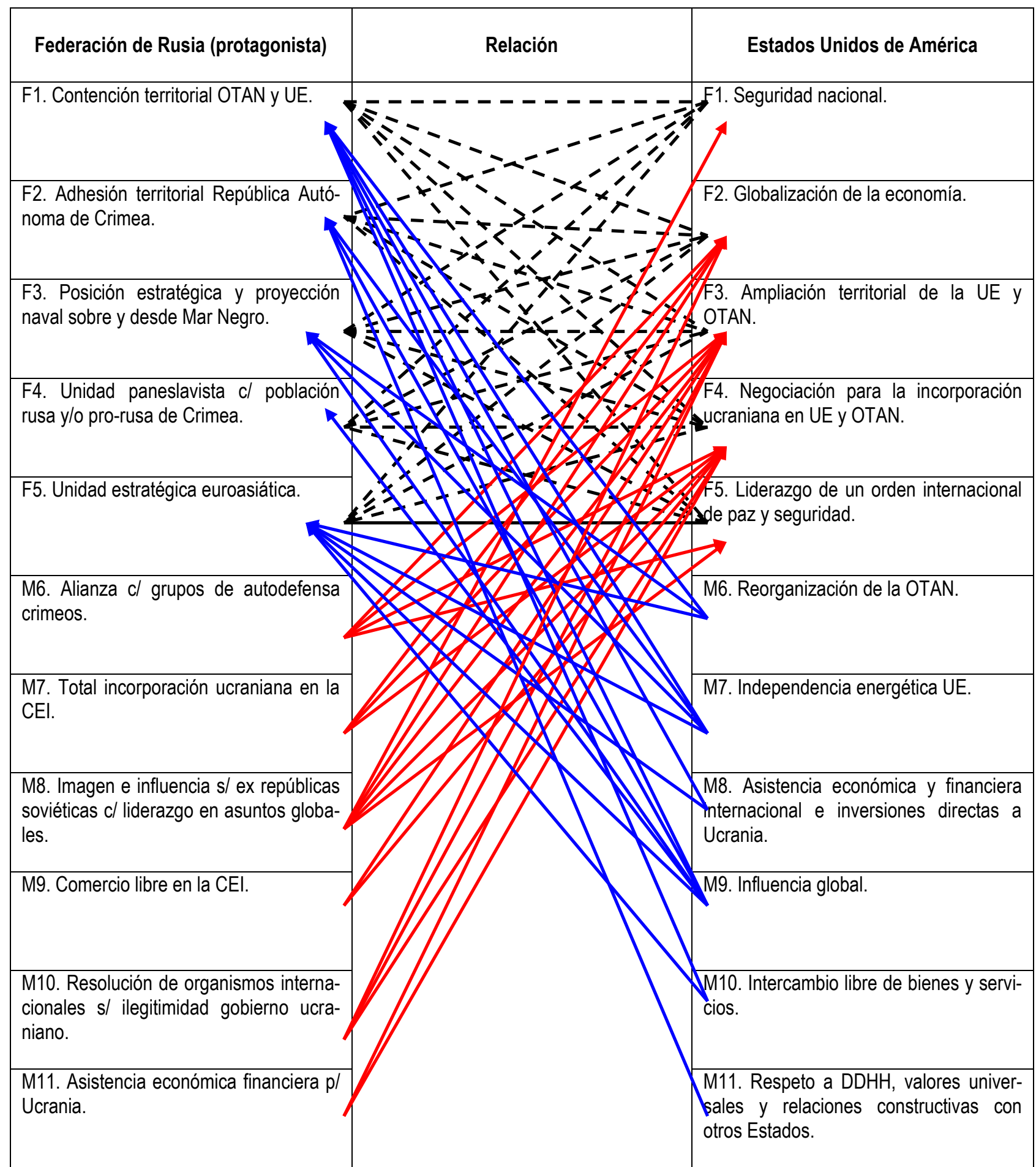

IDENTIFICACIÓN: fines con fines.

PODER: medios a fines.

FUERZA: medios de cambio a medios de cambio. Relación cuantitativa.
Cooperación

Competencia

$\mathrm{Fp} / \mathrm{Fa}$ 
Planilla 13. Relaciones de intereses Federación de Rusia - Reino Unido de Gran Bretaña e Irlanda del Norte

\begin{tabular}{|c|c|c|}
\hline Federación de Rusia (protagonista) & Relación & R. U. de G. B. e Irlanda del Norte \\
\hline F1. Contención territorial OTAN y UE. & & F1. Seguridad nacional. \\
\hline $\begin{array}{l}\text { F2. Adhesión territorial República Au } \\
\text { noma de Crimea. }\end{array}$ & & $\begin{array}{l}\text { F2. Globalización económica con uso } \\
\text { óptimo de recursos. }\end{array}$ \\
\hline $\begin{array}{l}\text { F3. Posición estratégica y proyecció } \\
\text { naval sobre y desde Mar Negro. }\end{array}$ & & 3. Seguridad colectiva. \\
\hline $\begin{array}{l}\text { F4. Unidad paneslavista cl poblac } \\
\text { rusa y/o pro-rusa de Crimea. }\end{array}$ & & $\begin{array}{l}\text { F4. Ampliación territorial de la UE y } \\
\text { OTAN. }\end{array}$ \\
\hline F5. Unidad estratégica euroasiática. & & 5. Pactos externos en seguridad y \\
\hline $\begin{array}{l}\text { M6. Alianza c/ grupos de autodefens } \\
\text { crimeos. }\end{array}$ & & $\begin{array}{l}\text { M6. Concepto estratégico nuevo y reor- } \\
\text { ganización de la OTAN. }\end{array}$ \\
\hline $\begin{array}{l}\text { M7. Total incorporación ucraniana en la } \\
\text { CEl. }\end{array}$ & & $\begin{array}{l}\text { M7. Coordinación políticas exterior, } \\
\text { seguridad y defensa por fuera UE. }\end{array}$ \\
\hline $\begin{array}{l}\text { M8. Imagen e influencia s/ ex república } \\
\text { soviéticas c/ liderazgo en asuntos globa } \\
\text { les. }\end{array}$ & & $\begin{array}{l}\text { M8. Presencia en ONU, OTAN, UE, G8, } \\
\text { G20 y Commonwealth. }\end{array}$ \\
\hline M9. Comercio libre en la CEI. & & M9. Prevención de conflictos y coordina- \\
\hline $\begin{array}{l}\text { M10. Resolución de organismos interna } \\
\text { cionales s/ ilegitimidad gobierno ucra } \\
\text { niano. }\end{array}$ & & M10. Ciberespacio seguro. \\
\hline $\begin{array}{l}\text { M11. Asistencia económica financiera } \mathrm{p} \\
\text { Ucrania. }\end{array}$ & & $\begin{array}{l}\text { M11. Integración económica de libre } \\
\text { comercio. }\end{array}$ \\
\hline
\end{tabular}

IDENTIFICACIÓN: fines con fines

PODER: medios a fines.

FUERZA: medios de cambio a medios de cambio. Relación cuantitativa.
Cooperación

Competencia

$\mathrm{Fp} / \mathrm{Fa}$ 
Planilla 14. Relaciones de intereses Federación de Rusia - República de Polonia

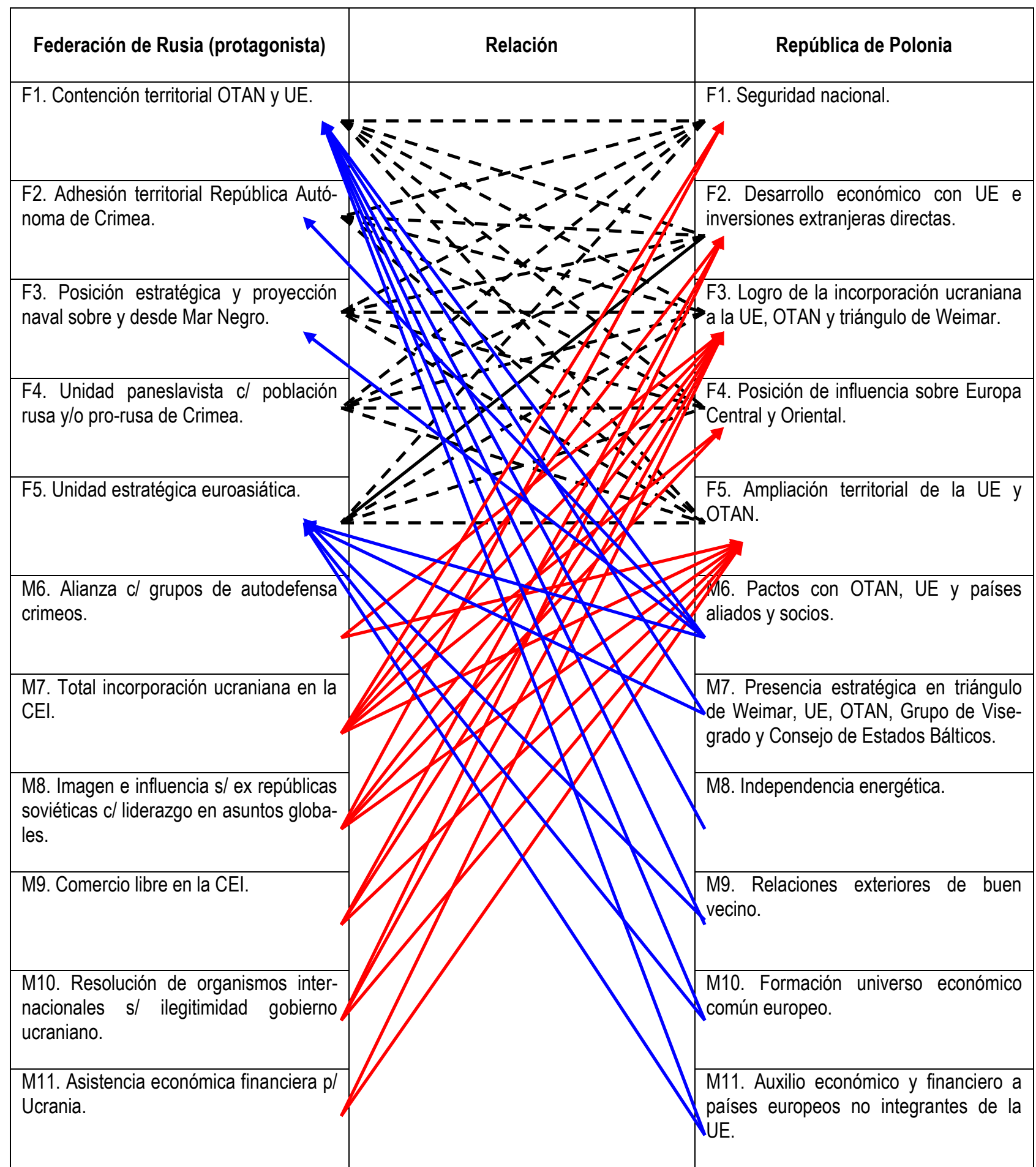

IDENTIFICACIÓN: fines con fines.

PODER: medios a fines.

FUERZA: medios de cambio a medios de cambio. Relación cuantitativa.
Cooperación

Competencia

$\mathrm{Fp} / \mathrm{Fa}$ 
Planilla 15. Relaciones de intereses Federación de Rusia - República de Turquía

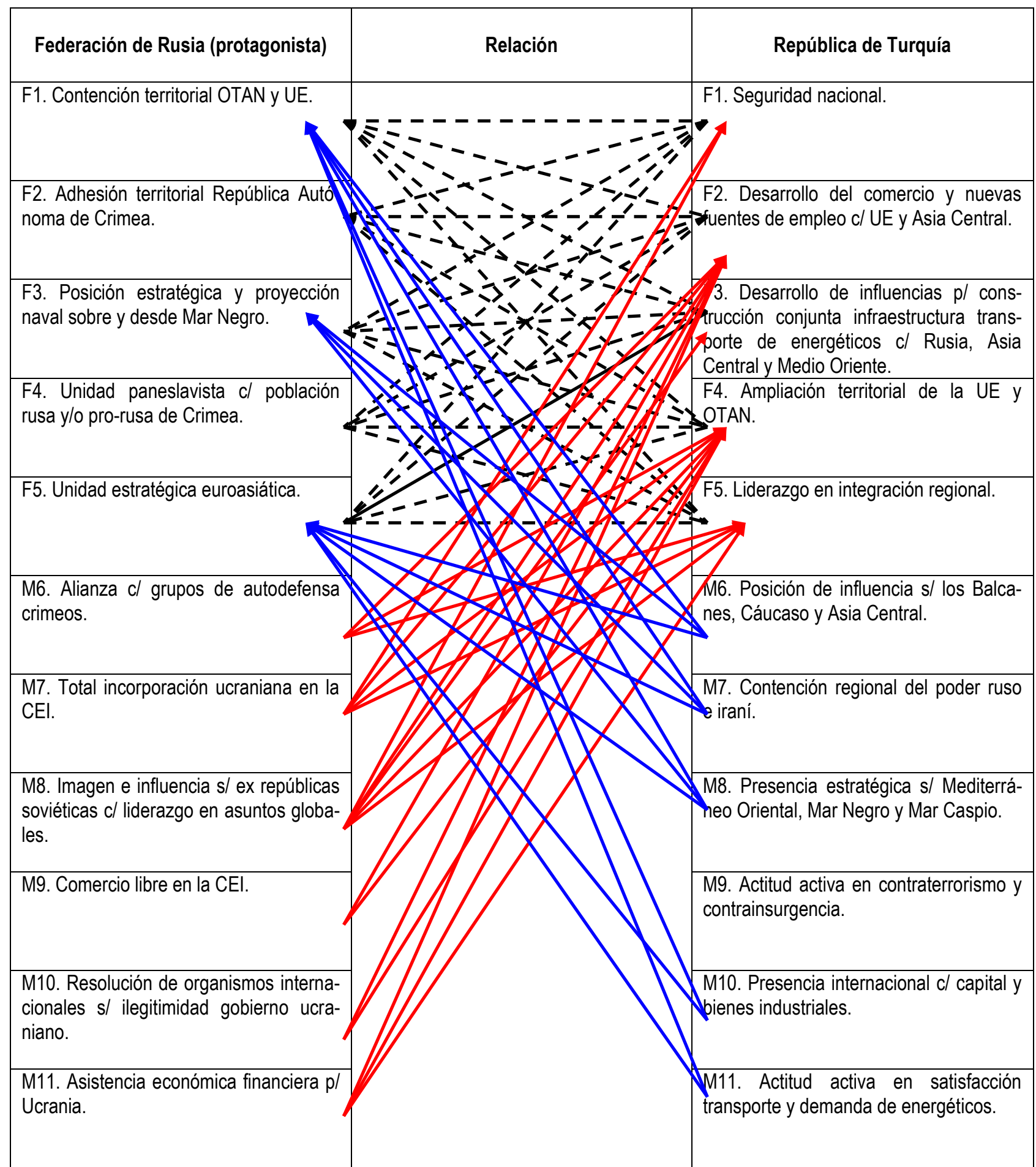

IDENTIFICACIÓN: fines con fines.

PODER: medios a fines.

FUERZA: medios de cambio a medios de cambio. Relación cuantitativa.
Cooperación

Competencia

$\mathrm{Fp} / \mathrm{Fa}$ 
Planilla 16. Relaciones de intereses Federación de Rusia - República Federal de Alemania

\begin{tabular}{|c|c|c|}
\hline Federación de Rusia (protagonista) & Relación & República Federal de Alemania \\
\hline F1. Contención territorial OTAN y UE. & & F1. Seguridad nacional. \\
\hline \multicolumn{3}{|c|}{$\begin{array}{l}\text { F2. Adhesión territorial República Autó- } \\
\text { noma de Crimea. }\end{array}$} \\
\hline $\begin{array}{l}\text { F3. Posición estratégica y proyecció } \\
\text { naval sobre y desde Mar Negro. }\end{array}$ & & $\begin{array}{l}\text { F3. Ampliación territorial de la UE y } \\
\text { OTAN. }\end{array}$ \\
\hline \multicolumn{3}{|c|}{$\begin{array}{l}\text { F4. Unidad paneslavista } \mathrm{cl} \text { población } \\
\text { rusa y/o pro-rusa de Crimea. }\end{array}$} \\
\hline \multicolumn{3}{|c|}{ F5. Unidad estratégica euroasiática. } \\
\hline \multicolumn{3}{|l|}{$\begin{array}{l}\text { M6. Alianza cl grupos de autodefenst } \\
\text { crimeos. }\end{array}$} \\
\hline \multicolumn{3}{|l|}{$\begin{array}{l}\text { M7. Total incorporación ucraniana en la } \\
\text { CEl. }\end{array}$} \\
\hline $\begin{array}{l}\text { M8. Imagen e influencia s/ ex república } \\
\text { soviéticas c/ liderazgo en asuntos globa }\end{array}$ & & M8. Cooperación transnacional europea. \\
\hline \multicolumn{3}{|l|}{ M9. Comercio libre en la CEI. } \\
\hline \multicolumn{3}{|l|}{$\begin{array}{l}\text { M10. Resolución de organismos interna- } \\
\text { cionales s/ ilegitimidad gobierno ucra- } \\
\text { niano. }\end{array}$} \\
\hline $\begin{array}{l}\text { M11. Asistencia económica financier } \\
\text { para Ucrania. }\end{array}$ & & $\begin{array}{l}\text { M11. Política activa de influencias s/ } \\
\text { Europa Central, Estados Bálticos, Ucra- } \\
\text { nia, Bielorrusia y Rusia. }\end{array}$ \\
\hline
\end{tabular}

IDENTIFICACIÓN: fines con fines.

PODER: medios a fines.

FUERZA: medios de cambio a medios de cambio. Relación cuantitativa.
Cooperación

Competencia

$\mathrm{Fp} / \mathrm{Fa}$ 
Planilla 17. Relaciones de intereses Federación de Rusia - República Francesa

\begin{tabular}{|c|c|c|}
\hline Federación de Rusia (protagonista) & Relación & República Francesa \\
\hline F1. Contención territorial OTAN y UE. & & F1. Seguridad nacional. \\
\hline $\begin{array}{l}\text { F2. Adhesión territorial República } \mathrm{AL} \\
\text { noma de Crimea. }\end{array}$ & & F2. Disuasión nuclear. \\
\hline $\begin{array}{l}\text { F3. Posición estratégica y proyecc } \\
\text { naval sobre y desde Mar Negro. }\end{array}$ & & F3. Pacto seguridad EEUU - UE. \\
\hline $\begin{array}{l}\text { F4. Unidad paneslavista cl poblaci } \\
\text { rusa y/o pro-rusa de Crimea. }\end{array}$ & & $\begin{array}{l}\text { Ampliación territorial de la UE y } \\
\text { AN. }\end{array}$ \\
\hline F5. Unidad estratégica euroasiática. & & 5. Liderazgo UE e influencia en su \\
\hline $\begin{array}{l}\text { M6. Alianza c/ grupos de autodefensa } \\
\text { crimeos. }\end{array}$ & & $\begin{array}{l}\text { M6. Presencia activa s/ triángulo de } \\
\text { Weimar, UE, OTAN, ONU y países } \\
\text { francófonos africanos. }\end{array}$ \\
\hline $\begin{array}{l}\text { M7. Total incorporación ucraniana en la } \\
\text { CEI. }\end{array}$ & & $\begin{array}{l}\text { M7. Pactos cl OTAN, UE y países alia- } \\
\text { dos y socios. }\end{array}$ \\
\hline $\begin{array}{l}\text { M8. Imagen e influencia s/ ex repúblicas } \\
\text { soviéticas c/ liderazgo en asuntos globa- } \\
\text { les. }\end{array}$ & & $\begin{array}{l}\text { M8. Operaciones militares conjuntas con } \\
\text { RU. }\end{array}$ \\
\hline M9. Comercio libre en la CEI. & & M9. Relevancia UE en la reorganización \\
\hline $\begin{array}{l}\text { M10. Resolución de organismos interna } \\
\text { cionales s/ ilegitimidad gobierno ucra } \\
\text { niano. }\end{array}$ & & $\begin{array}{l}\text { M10. Posición de influencia s/ países } \\
\text { puropeos mediterráneo occidentales. }\end{array}$ \\
\hline $\begin{array}{l}\text { M11. Asistencia económica financiera } p \\
\text { Ucrania. }\end{array}$ & & M11. Mediación UE - Rusia. \\
\hline
\end{tabular}

IDENTIFICACIÓN: fines con fines.

PODER: medios a fines.

FUERZA: medios de cambio a medios de cambio. Relación cuantitativa.
Cooperación

Competencia

$\mathrm{Fp} / \mathrm{Fa}$ 
Planilla 18. Relaciones de intereses Federación de Rusia - República Islámica de Irán

\begin{tabular}{|c|c|c|}
\hline Federación de Rusia (protagonista) & Relación & República Islámica de Irán \\
\hline F1. Contención territorial OTAN y UE. & & F1. Seguridad nacional. \\
\hline $\begin{array}{l}\text { F2. Adhesión territorial República } A \\
\text { noma de Crimea. }\end{array}$ & & Desarrollo programa nuclear. \\
\hline $\begin{array}{l}\text { F3. Posición estratégica y proyecc } \\
\text { naval sobre y desde Mar Negro. }\end{array}$ & & $\begin{array}{l}\text { Relaciones exteriores de intereses } \\
\text { onales. }\end{array}$ \\
\hline $\begin{array}{l}\text { F4. Unidad paneslavista } \mathrm{cl} \text { pobla } \\
\text { rusa y/o pro-rusa de Crimea. }\end{array}$ & & F4. Desarrollo económico sustentable. \\
\hline F5. Unidad estratégica euroasiática. & & Posición de influencia s/ Cáucaso, \\
\hline $\begin{array}{l}\text { M6. Alianza c/ grupos de autodefe } \\
\text { crimeos. }\end{array}$ & & $\begin{array}{l}\text { M6. Disuasión nuclear s/ fuerzas occi- } \\
\text { dentales y contención de grupos étnicos }\end{array}$ \\
\hline $\begin{array}{l}\text { M7. Total incorporación ucraniana en la } \\
\text { CEI. }\end{array}$ & & M7. Desarrollo de misiles balísticos. \\
\hline $\begin{array}{l}\text { M8. Imagen e influencia s/ ex república } \\
\text { soviéticas c/ liderazgo en asuntos globa } \\
\text { les. }\end{array}$ & & $\begin{array}{l}\text { M8. Pactos con Rusia, Corea del Norte, } \\
\text { Siria y Armenia. }\end{array}$ \\
\hline M9. Comercio libre en la CEl. & & $\begin{array}{l}\text { M9. Acciones } \mathrm{p} / \text { comercialización de } \\
\text { crudo y proyección } \mathrm{p} / \text { infraestructura } \\
\text { propia refinado de petróleo. }\end{array}$ \\
\hline $\begin{array}{l}\text { M10. Resolución de organismos interna } \\
\text { cionales s/ ilegitimidad gobierno ucra } \\
\text { niano. }\end{array}$ & & $\begin{array}{l}\text { M10. Comercio ruso iraní } \mathrm{c} / \text { proyectos } \\
\text { energéticos conjuntos y turco iraní s/ } \\
\text { energéticos. }\end{array}$ \\
\hline $\begin{array}{l}\text { M11. Asistencia económica financiera p } \\
\text { Ucrania. }\end{array}$ & & $\begin{array}{l}\text { M11. Negociaciones s/ programa nuclear } \\
\text { y posición en Estrecho de Ormuz c/ UE, } \\
\text { EEUU y ONU. }\end{array}$ \\
\hline
\end{tabular}

IDENTIFICACIÓN: fines con fines.

PODER: medios a fines.

FUERZA: medios de cambio a medios de cambio. Relación cuantitativa.
Cooperación

Competencia

$\mathrm{Fp} / \mathrm{Fa}$ 
Planilla 19. Relaciones de intereses Federación de Rusia - República Popular de China

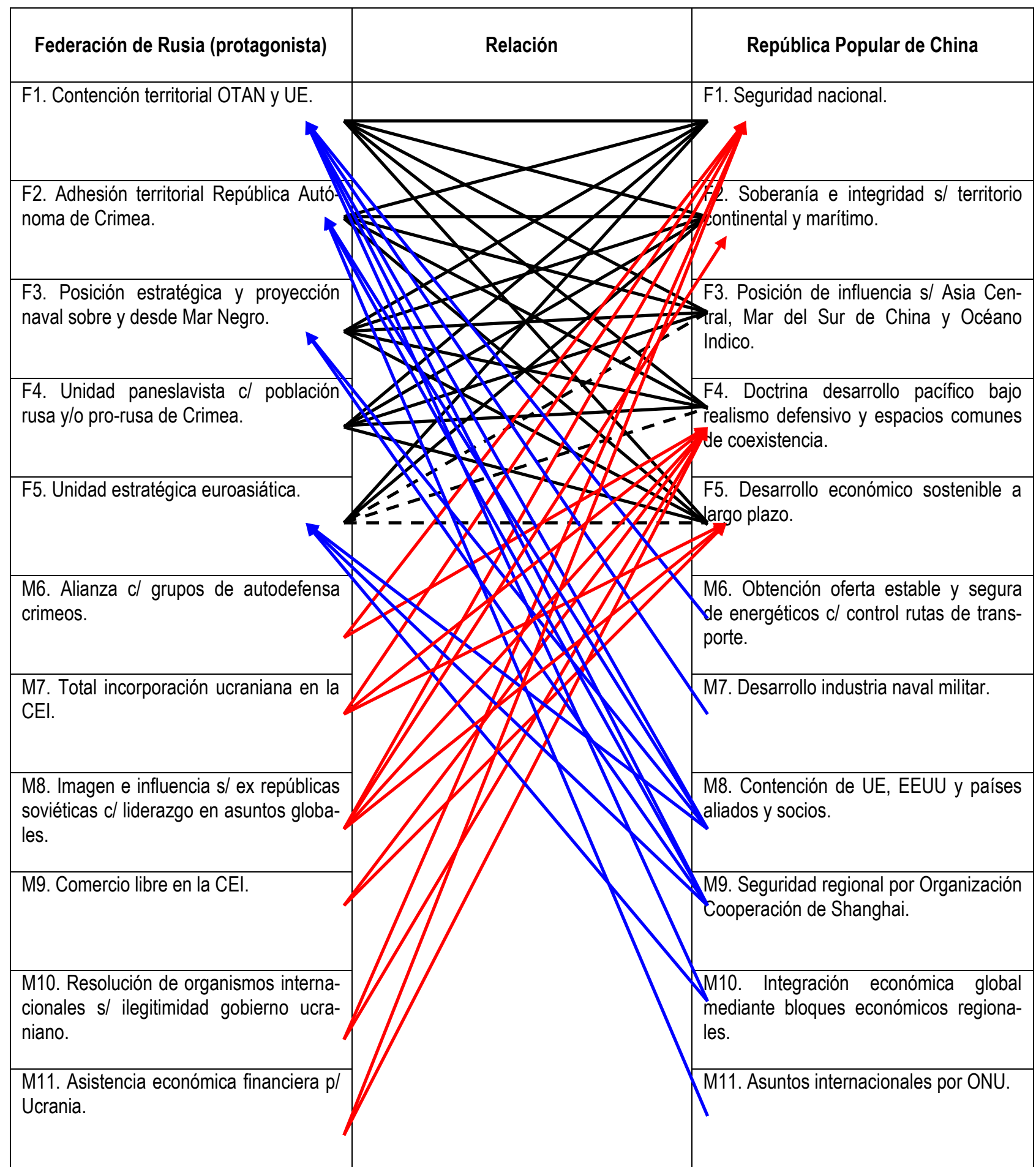

IDENTIFICACIÓN: fines con fines.

PODER: medios a fines.

FUERZA: medios de cambio a medios de cambio. Relación cuantitativa.
Cooperación

Competencia

$\mathrm{Fp} / \mathrm{Fa}$ 
Planilla 20. Relaciones de intereses Ucrania - Estados Unidos de América

\begin{tabular}{|c|c|c|}
\hline Ucrania & Relación & Estados Unidos de América \\
\hline F1. Integridad territorial. & & F1. Seguridad nacional. \\
\hline F2. Soberanía estatal. & & F2. Globalización de la economía. \\
\hline $\begin{array}{l}\text { F3. Negociación para la incorporación en } \\
\text { UE y OTAN. }\end{array}$ & & $\begin{array}{l}\text { F3. Ampliación territorial de la UE y } \\
\text { OTAN. }\end{array}$ \\
\hline $\begin{array}{l}\text { F4. Unidad nacional c/ diversidad políti } \\
\text { y poblacional. }\end{array}$ & & $\begin{array}{l}\text { Negociación para la incorporación } \\
\text { aniana en UE y OTAN. }\end{array}$ \\
\hline F5. Independencia energética. & & F5. Liderazgo de un orden internacional \\
\hline $\begin{array}{l}\text { M6. Retiro fuerzas rusas y desarme } \\
\text { autodefensas pro-rusas. }\end{array}$ & & Reorganización de la OTAN. \\
\hline $\begin{array}{l}\text { M7. Ayuda internacional ante fuerzas } \\
\text { rusas de ocupación. }\end{array}$ & & M7. Independencia energética UE. \\
\hline $\begin{array}{l}\text { M8. Negociación por energéticos y } \\
\text { tránsito de energéticos rusos. }\end{array}$ & & $\begin{array}{l}\text { M8. Asistencia económica y financiera } \\
\text { internacional e inversiones directas a }\end{array}$ \\
\hline $\begin{array}{l}\text { M9. Política activa de liderazgo de una } \\
\text { CEl sólo económica y comercial. }\end{array}$ & & M9. Influencia global. \\
\hline $\begin{array}{l}\text { M10. Resolución de organismos interna- } \\
\text { cionales contra anexión de Crimea. }\end{array}$ & & $\begin{array}{l}\text { M10. Intercambio libre de bienes y servi- } \\
\text { cios. }\end{array}$ \\
\hline $\begin{array}{l}\text { M11. Obtención asistencia económica } \\
\text { financiera internacional e inversiones } \\
\text { extranjeras directas. }\end{array}$ & & $\begin{array}{l}\text { M11. Respeto a DDHH, valores univer- } \\
\text { sales y relaciones constructivas con } \\
\text { otros Estados. }\end{array}$ \\
\hline
\end{tabular}

IDENTIFICACIÓN: fines con fines.

PODER: medios a fines.

FUERZA: medios de cambio a medios de cambio. Relación cuantitativa.
Cooperación

Competencia

$\mathrm{Fp} / \mathrm{Fa}$ 
Planilla 21. Relaciones de intereses Ucrania - Reino Unido de Gran Bretaña e Irlanda del Norte

\begin{tabular}{|c|c|c|}
\hline Ucrania & Relación & R. U. de G. B. e Irlanda del Norte \\
\hline F1. Integridad territorial. & & F1. Seguridad nacional. \\
\hline F2. Soberanía estatal. & & F2. Globalización económica con uso \\
\hline $\begin{array}{l}\text { F3. Negociación para la incorporació } \\
\text { UE y OTAN. }\end{array}$ & & eguridad colectiva. \\
\hline $\begin{array}{l}\text { F4. Unidad nacional c/ diversidad pol } \\
\text { y poblacional. }\end{array}$ & & $\begin{array}{l}\text { F4. Ampliación territorial de la UE y } \\
\text { OTAN. }\end{array}$ \\
\hline F5. Independencia energética. & & Pactos externos en seguridad y \\
\hline $\begin{array}{l}\text { M6. Retiro fuerzas rusas y desarme } \\
\text { autodefensas pro-rusas. }\end{array}$ & & $\begin{array}{l}\text { Concepto estratégico nuevo y reor- } \\
\text { ización de la OTAN. }\end{array}$ \\
\hline $\begin{array}{l}\text { M7. Ayuda internacional ante fuerzas } \\
\text { rusas de ocupación. }\end{array}$ & & $\begin{array}{l}\text { M7. Coordinación políticas exterior, } \\
\text { seguridad y defensa por fuera UE. }\end{array}$ \\
\hline $\begin{array}{l}\text { M8. Negociación por energéticos y } \\
\text { tránsito de energéticos rusos. }\end{array}$ & & $\begin{array}{l}\text { M8. Presencia en ONU, OTAN, UE, G8, } \\
\text { G20 y Commonwealth. }\end{array}$ \\
\hline $\begin{array}{l}\text { M9. Política activa de liderazgo de una } \\
\text { CEI sólo económica y comercial. }\end{array}$ & & $\begin{array}{l}\text { M9. Prevención de conflictos y coordina- } \\
\text { ción ONU, OTAN y UE. }\end{array}$ \\
\hline $\begin{array}{l}\text { M10. Resolución de organismos interna- } \\
\text { cionales contra anexión de Crimea. }\end{array}$ & & M10. Ciberespacio seguro. \\
\hline $\begin{array}{l}\text { M11. Obtención asistencia económica } \\
\text { financiera internacional e inversiones } \\
\text { extranjeras directas. }\end{array}$ & & $\begin{array}{l}\text { M11. Integración económica de libre } \\
\text { comercio. }\end{array}$ \\
\hline
\end{tabular}

IDENTIFICACIÓN: fines con fines.

PODER: medios a fines.

FUERZA: medios de cambio a medios de cambio. Relación cuantitativa.

\section{Cooperación}

Competencia

$\mathrm{Fp} / \mathrm{Fa}$ 
Planilla 22. Relaciones de intereses Ucrania - República de Polonia

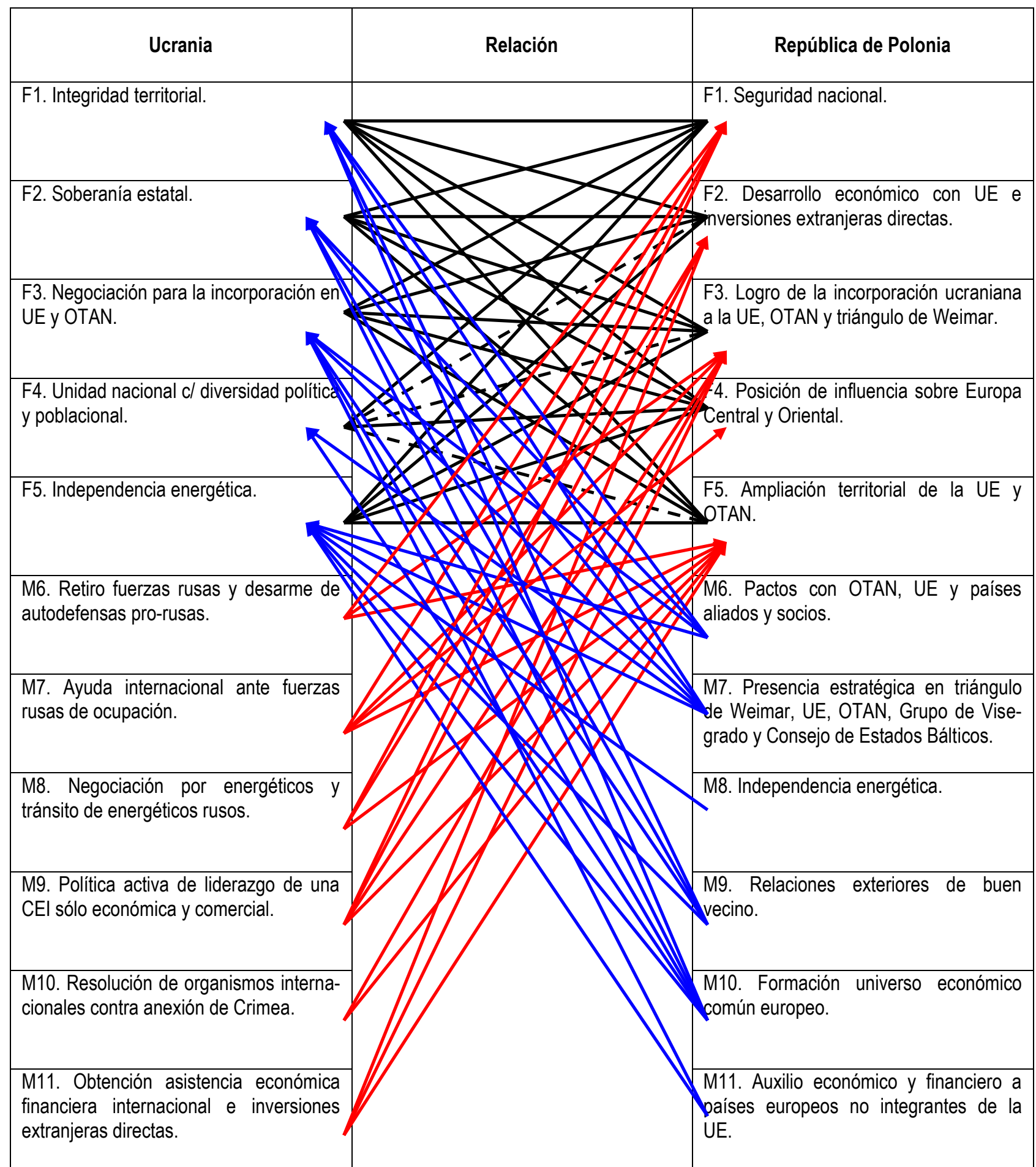

IDENTIFICACIÓN: fines con fines.

PODER: medios a fines.

FUERZA: medios de cambio a medios de cambio. Relación cuantitativa.
Cooperación

Competencia

$\mathrm{Fp} / \mathrm{Fa}$ 
Planilla 23. Relaciones de intereses Ucrania - República de Turquía

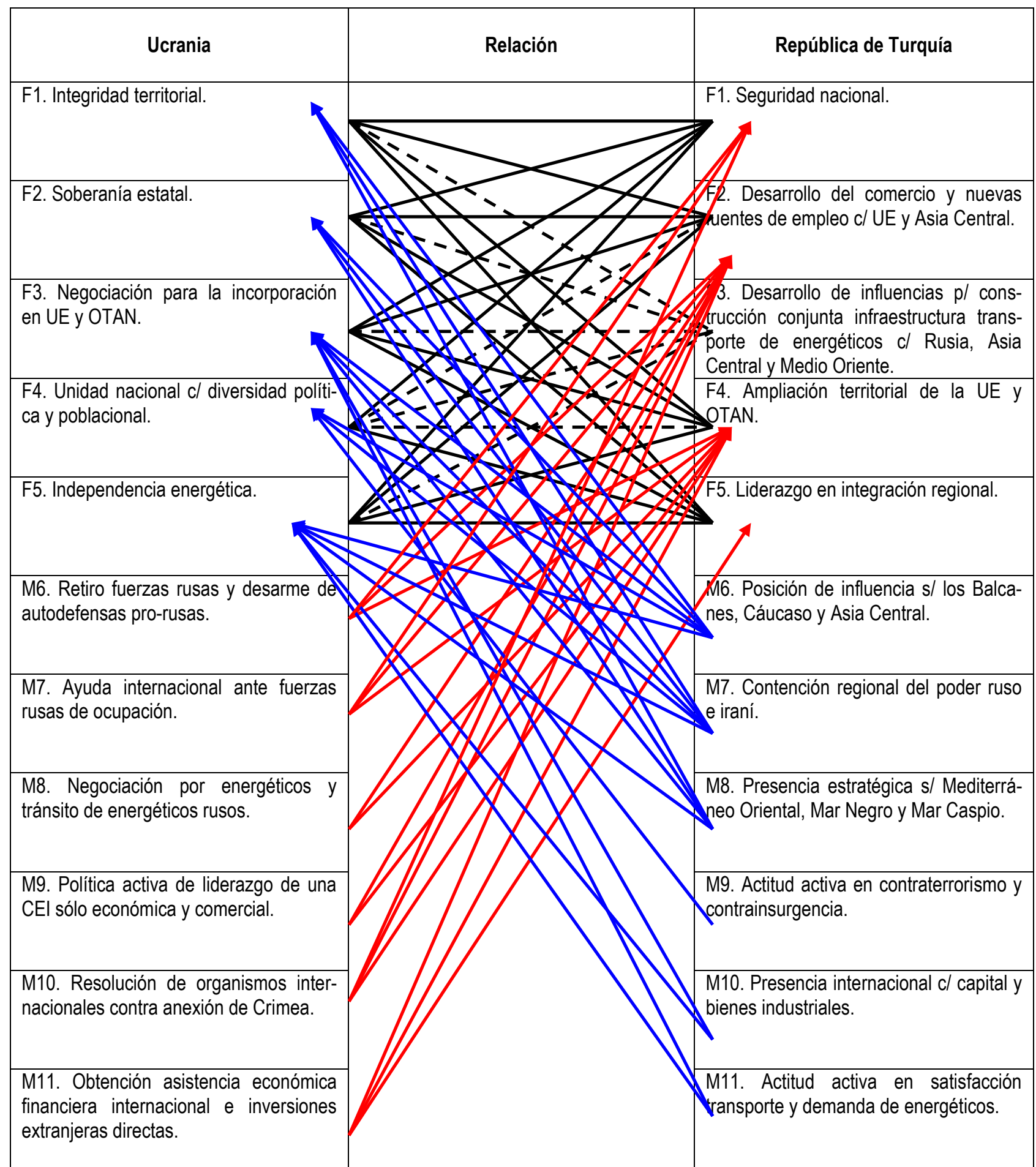

IDENTIFICACIÓN: fines con fines.

PODER: medios a fines.

FUERZA: medios de cambio a medios de cambio. Relación cuantitativa.
Cooperación

Competencia

$\mathrm{Fp} / \mathrm{Fa}$ 
Planilla 24. Relaciones de intereses Ucrania - República Federal de Alemania

\begin{tabular}{|c|c|c|}
\hline Ucrania & Relación & República Federal de Alemania \\
\hline F1. Integridad territorial. & & F1. Seguridad nacional. \\
\hline F2. Soberanía estatal. & & Desarrollo económico con UE. \\
\hline $\begin{array}{l}\text { F3. Negociación para la incorporació } \\
\text { UE y OTAN. }\end{array}$ & & $\begin{array}{l}\text { 3. Ampliación territorial de la UE y } \\
\text { OTAN. }\end{array}$ \\
\hline $\begin{array}{l}\text { F4. Unidad nacional c/ diversidad polític } \\
\text { y poblacional. }\end{array}$ & & $\begin{array}{l}\text { F4. Obtención del ingreso ucraniano a la } \\
\text { UE y OTAN. }\end{array}$ \\
\hline F5. Independencia energética. & & F. Liderazgo de la UE. \\
\hline $\begin{array}{l}\text { M6. Retiro fuerzas rusas y desarme } \\
\text { autodefensas pro-rusas. }\end{array}$ & & $\begin{array}{l}\text { M6. Pactos c/ EEUU, OTAN, UE y paí- } \\
\text { ses aliados y socios. }\end{array}$ \\
\hline $\begin{array}{l}\text { M7. Ayuda internacional ante fuerzas } \\
\text { rusas de ocupación. }\end{array}$ & & $\begin{array}{l}\text { M7. Presencia activa s/ triángulo de } \\
\text { Weimar, UE y OTAN. }\end{array}$ \\
\hline $\begin{array}{l}\text { M8. Negociación por energéticos y } \\
\text { tránsito de energéticos rusos. }\end{array}$ & & M8. Cooperación transnacional europea. \\
\hline $\begin{array}{l}\text { M9. Política activa de liderazgo de una } \\
\text { CEl sólo económica y comercial. }\end{array}$ & & $\begin{array}{l}\text { M9. Inversiones y comercio libre cl } \\
\text { Europa Central, Estados Bálticos, Ucra- }\end{array}$ \\
\hline $\begin{array}{l}\text { M10. Resolución de organismos interna- } \\
\text { cionales contra anexión de Crimea. }\end{array}$ & & M10. Política positiva de buen vecino. \\
\hline $\begin{array}{l}\text { M11. Obtención asistencia económica } \\
\text { financiera internacional e inversiones } \\
\text { extranjeras directas. }\end{array}$ & & $\begin{array}{l}\text { M11. Política activa de influencias s/ } \\
\text { Europa Central, Estados Bálticos, Ucra- } \\
\text { nia, Bielorrusia y Rusia. }\end{array}$ \\
\hline
\end{tabular}

IDENTIFICACIÓN: fines con fines.

PODER: medios a fines.

FUERZA: medios de cambio a medios de cambio. Relación cuantitativa.
Cooperación

Competencia

$\mathrm{Fp} / \mathrm{Fa}$ 
Planilla 25. Relaciones de intereses Ucrania - República Francesa

\begin{tabular}{|c|c|c|}
\hline Ucrania & Relación & República Francesa \\
\hline F1. Integridad territorial. & & F1. Seguridad nacional. \\
\hline F2. Soberanía estatal. & & Disuasión nuclear. \\
\hline $\begin{array}{l}\text { F3. Negociación para la incorporac } \\
\text { UE y OTAN. }\end{array}$ & & F3. Pacto seguridad EEUU - UE. \\
\hline $\begin{array}{l}\text { F4. Unidad nacional c/ diversidad polí } \\
\text { y poblacional. }\end{array}$ & & $\begin{array}{l}\text { Ampliación territorial de la UE y } \\
\text { AN. }\end{array}$ \\
\hline F5. Independencia energética. & & Liderazgo UE e influencia en su \\
\hline $\begin{array}{l}\text { M6. Retiro fuerzas rusas y desarme } \\
\text { autodefensas pro-rusas. }\end{array}$ & & $\begin{array}{l}\text { M6. Presencia activa s/ triángulo de } \\
\text { Weimar, UE, OTAN, ONU y países }\end{array}$ \\
\hline $\begin{array}{l}\text { M7. Ayuda internacional ante fuerzas } \\
\text { rusas de ocupación. }\end{array}$ & & $\begin{array}{l}\text { M7. Pactos c/ OTAN, UE y países alia- } \\
\text { dos y socios. }\end{array}$ \\
\hline $\begin{array}{l}\text { M8. Negociación por energéticos y } \\
\text { tránsito de energéticos rusos. }\end{array}$ & & $\begin{array}{l}\text { M8. Operaciones militares conjuntas con } \\
\text { RU. }\end{array}$ \\
\hline $\begin{array}{l}\text { M9. Política activa de liderazgo de una } \\
\text { CEI sólo económica y comercial. }\end{array}$ & & $\begin{array}{l}\text { M9. Relevancia UE en la reorganización } \\
\text { de la OTAN. }\end{array}$ \\
\hline $\begin{array}{l}\text { M10. Resolución de organismos interna- } \\
\text { cionales contra anexión de Crimea. }\end{array}$ & & $\begin{array}{l}\text { M10. Posición de influencia s/ países } \\
\text { europeos mediterráneo occidentales. }\end{array}$ \\
\hline $\begin{array}{l}\text { M11. Obtención asistencia económica } \\
\text { financiera internacional e inversiones } \\
\text { extranjeras directas. }\end{array}$ & & M11. Mediación UE - Rusia. \\
\hline
\end{tabular}

IDENTIFICACIÓN: fines con fines.

PODER: medios a fines.

FUERZA: medios de cambio a medios de cambio. Relación cuantitativa.
Cooperación Competencia

$\mathrm{Fp} / \mathrm{Fa}$ 
Planilla 26. Relaciones de intereses Ucrania - República Islámica de Irán

\begin{tabular}{|c|c|c|}
\hline Ucrania & Relación & República Islámica de Irán \\
\hline F1. Integridad territorial. & & F1. Seguridad nacional. \\
\hline F2. Soberanía estatal. & & 2. Desarrollo programa nuclear. \\
\hline $\begin{array}{l}\text { F3. Negociación para la incorporación } \\
\text { UE y OTAN. }\end{array}$ & & $\begin{array}{l}\text { F3. Relaciones exteriores de intereses } \\
\text { nacionales. }\end{array}$ \\
\hline $\begin{array}{l}\text { F4. Unidad nacional c/ diversidad pol } \\
\text { y poblacional. }\end{array}$ & & \\
\hline F5. Independencia energética. & & F5. Posición de influencia s/ Cáucaso, \\
\hline $\begin{array}{l}\text { M6. Retiro fuerzas rusas y desarme de } \\
\text { autodefensas pro-rusas. }\end{array}$ & & $\begin{array}{l}\text { de. Disuasión nuclear s/ fuerzas occi- } \\
\text { dentales y contención de grupos étnicos } \\
\text { y/o religiosos. }\end{array}$ \\
\hline $\begin{array}{l}\text { M7. Ayuda internacional ante fuerzas } \\
\text { rusas de ocupación. }\end{array}$ & & M7. Desarrollo de misiles balísticos. \\
\hline $\begin{array}{l}\text { M8. Negociación por energéticos y } \\
\text { tránsito de energéticos rusos. }\end{array}$ & & $\begin{array}{l}\text { M8. Pactos con Rusia, Corea del Norte, } \\
\text { Siria y Armenia. }\end{array}$ \\
\hline $\begin{array}{l}\text { M9. Política activa de liderazgo de una } \\
\text { CEl sólo económica y comercial. }\end{array}$ & & $\begin{array}{l}\text { M9. Acciones } \mathrm{p} / \text { comercialización de } \\
\text { crudo y proyección } \mathrm{p} / \text { infraestructura } \\
\text { propia refinado de petróleo. }\end{array}$ \\
\hline $\begin{array}{l}\text { M10. Resolución de organismos interna- } \\
\text { cionales contra anexión de Crimea. }\end{array}$ & & $\begin{array}{l}\text { M10. Comercio ruso iraní c/ proyectos } \\
\text { energéticos conjuntos y turco iraní s/ } \\
\text { energéticos. }\end{array}$ \\
\hline $\begin{array}{l}\text { M11. Obtención asistencia económica } \\
\text { financiera internacional e inversiones } \\
\text { extranjeras directas. }\end{array}$ & & $\begin{array}{l}\text { M11. Negociaciones s/ programa nuclear } \\
\text { v posición en Estrecho de Ormuz c/ UE, } \\
\text { EEUU y ONU. }\end{array}$ \\
\hline
\end{tabular}

IDENTIFICACIÓN: fines con fines.

PODER: medios a fines.

FUERZA: medios de cambio a medios de cambio. Relación cuantitativa.
Cooperación

Competencia

$\mathrm{Fp} / \mathrm{Fa}$ 
Planilla 27. Relaciones de intereses Ucrania - República Popular de China

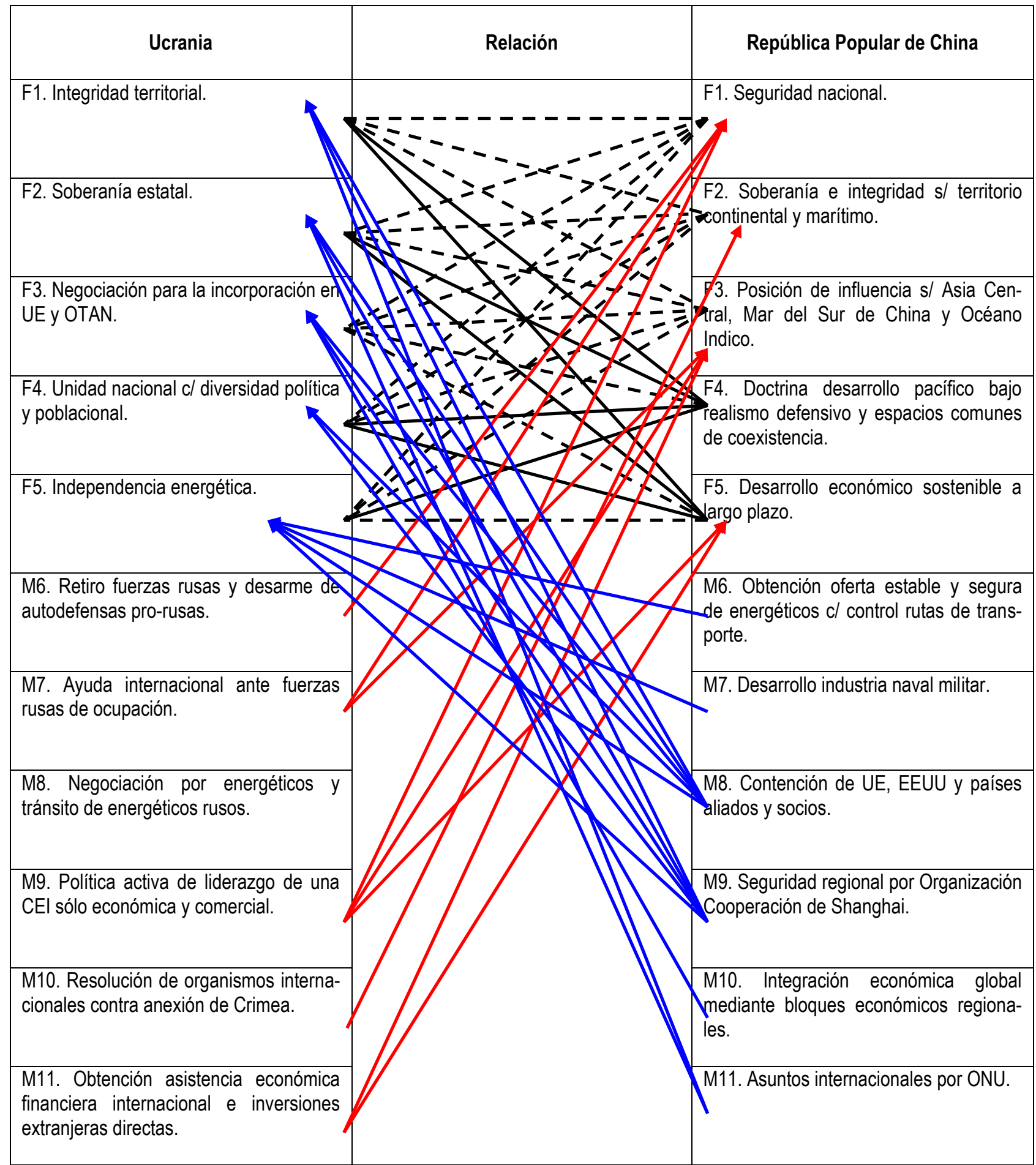

IDENTIFICACIÓN: fines con fines.

PODER: medios a fines.

FUERZA: medios de cambio a medios de cambio. Relación cuantitativa.
Cooperación

Competencia

$\mathrm{Fp} / \mathrm{Fa}$ 
Planilla 28. Relaciones de intereses Estados Unidos de América - R. U. de Gran Bretaña e Irlanda del Norte

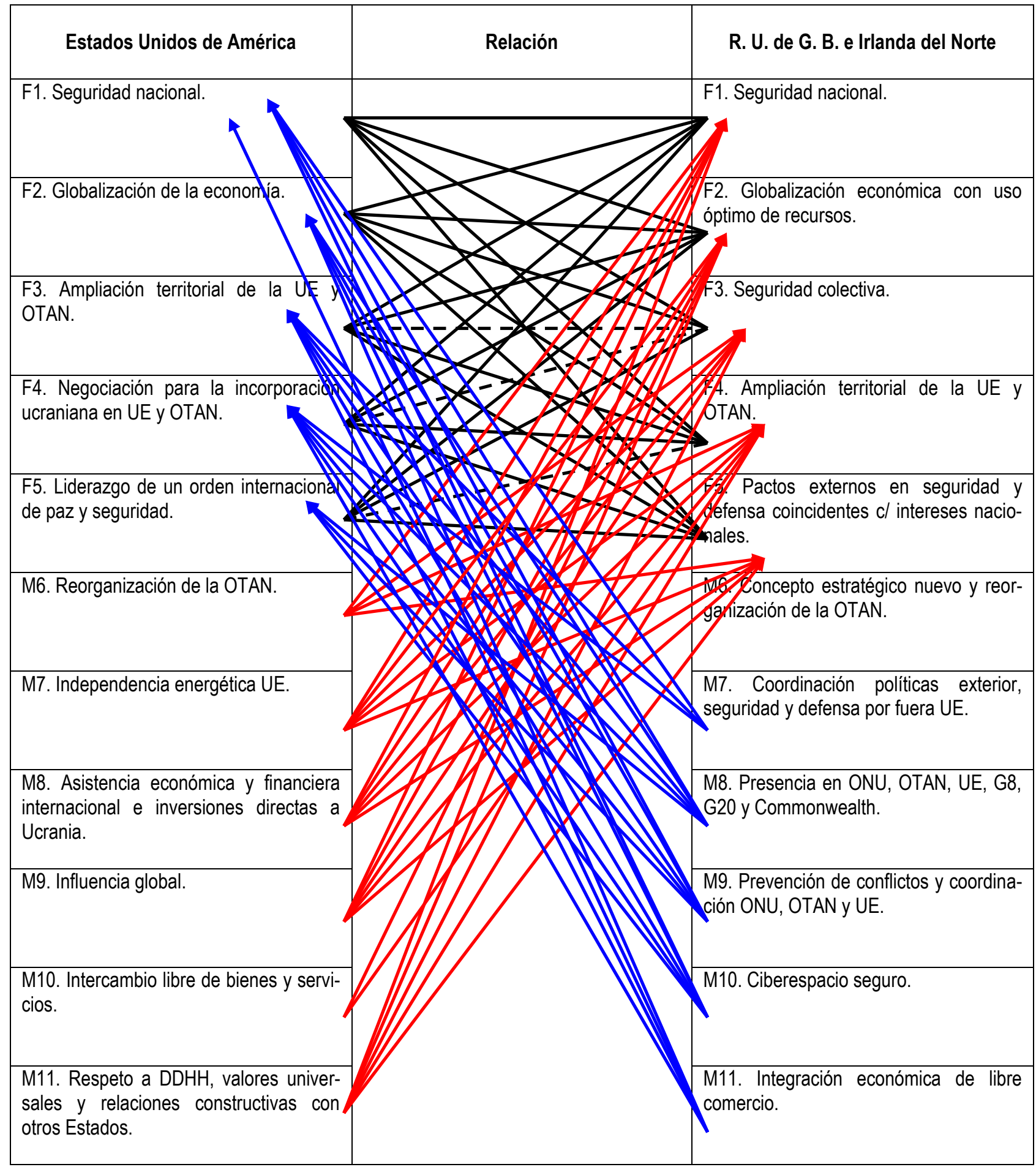

IDENTIFICACIÓN: fines con fines.

PODER: medios a fines.

FUERZA: medios de cambio a medios de cambio. Relación cuantitativa.
Cooperación

Competencia

$\mathrm{Fp} / \mathrm{Fa}$ 
Planilla 29. Relaciones de intereses Estados Unidos de América - República de Polonia

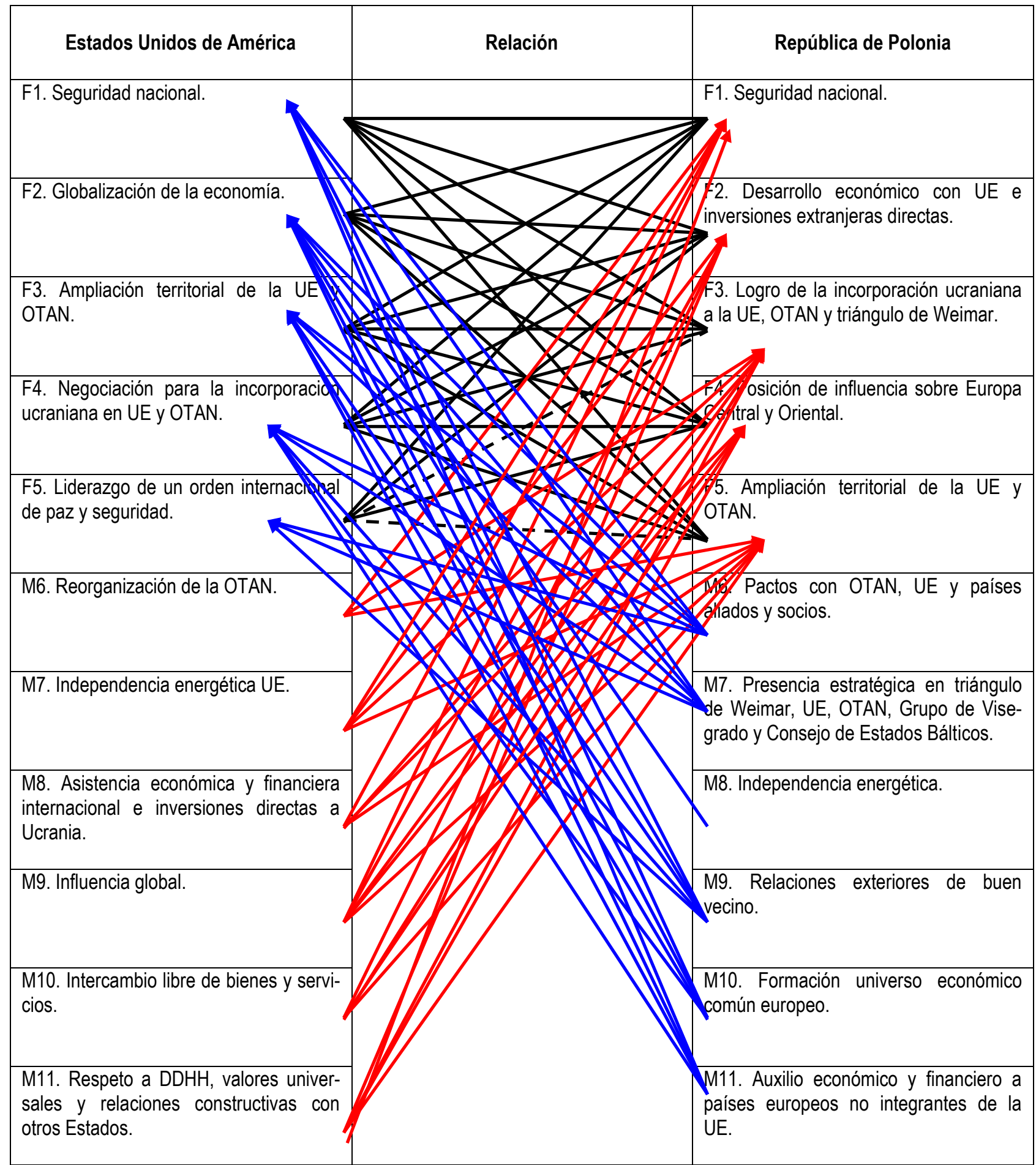

IDENTIFICACIÓN: fines con fines.

PODER: medios a fines.

FUERZA: medios de cambio a medios de cambio. Relación cuantitativa.
Cooperación

Competencia

$\mathrm{Fp} / \mathrm{Fa}$ 
Planilla 30. Relaciones de intereses Estados Unidos de América - República de Turquía

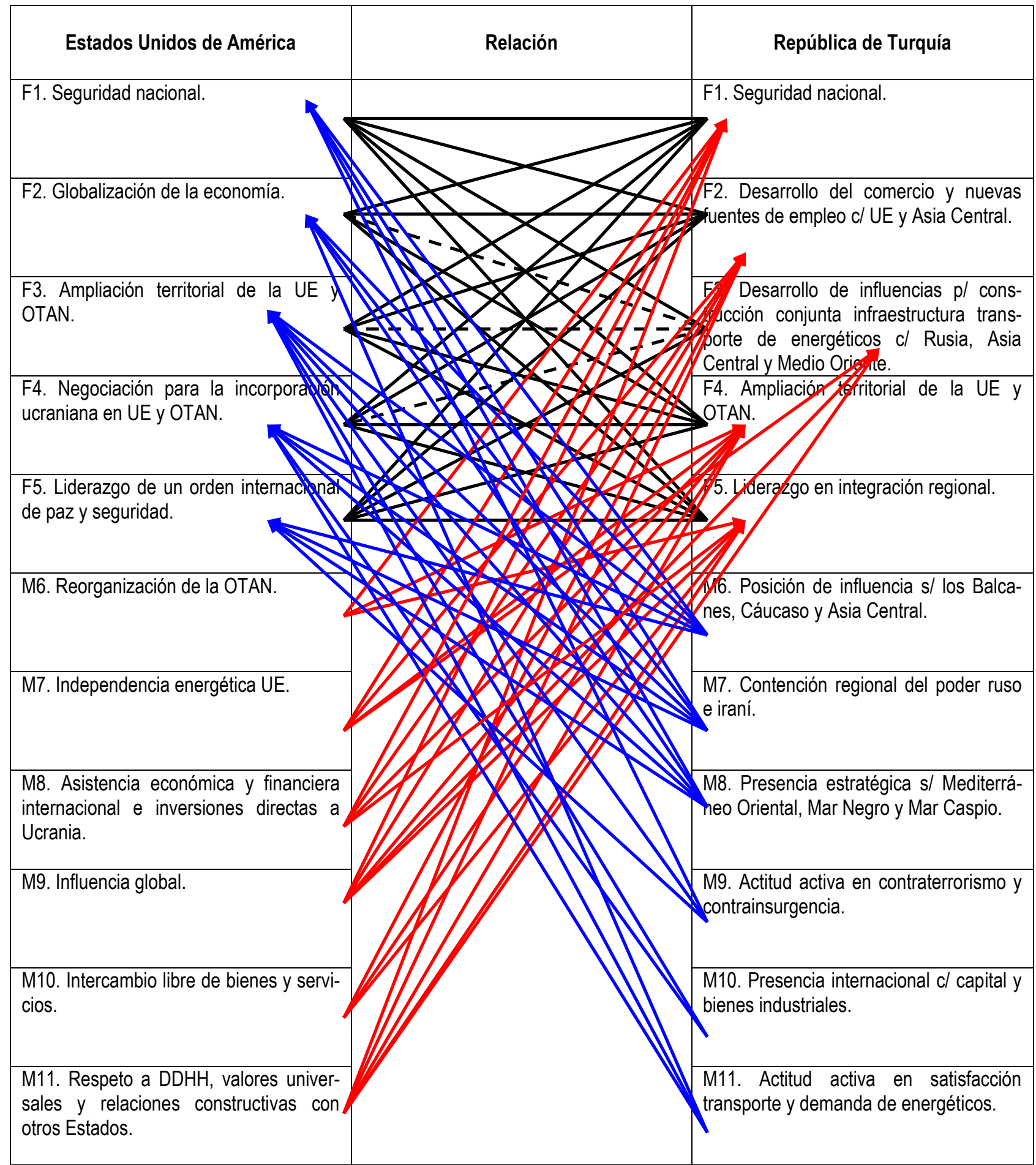

IDENTIFICACIÓN: fines con fines.

PODER: medios a fines.

FUERZA: medios de cambio a medios de cambio. Relación cuantitativa.
Cooperación Competencia

$\mathrm{Fp} / \mathrm{Fa}$ 
Planilla 31. Relaciones de intereses Estados Unidos de América - República Federal de Alemania

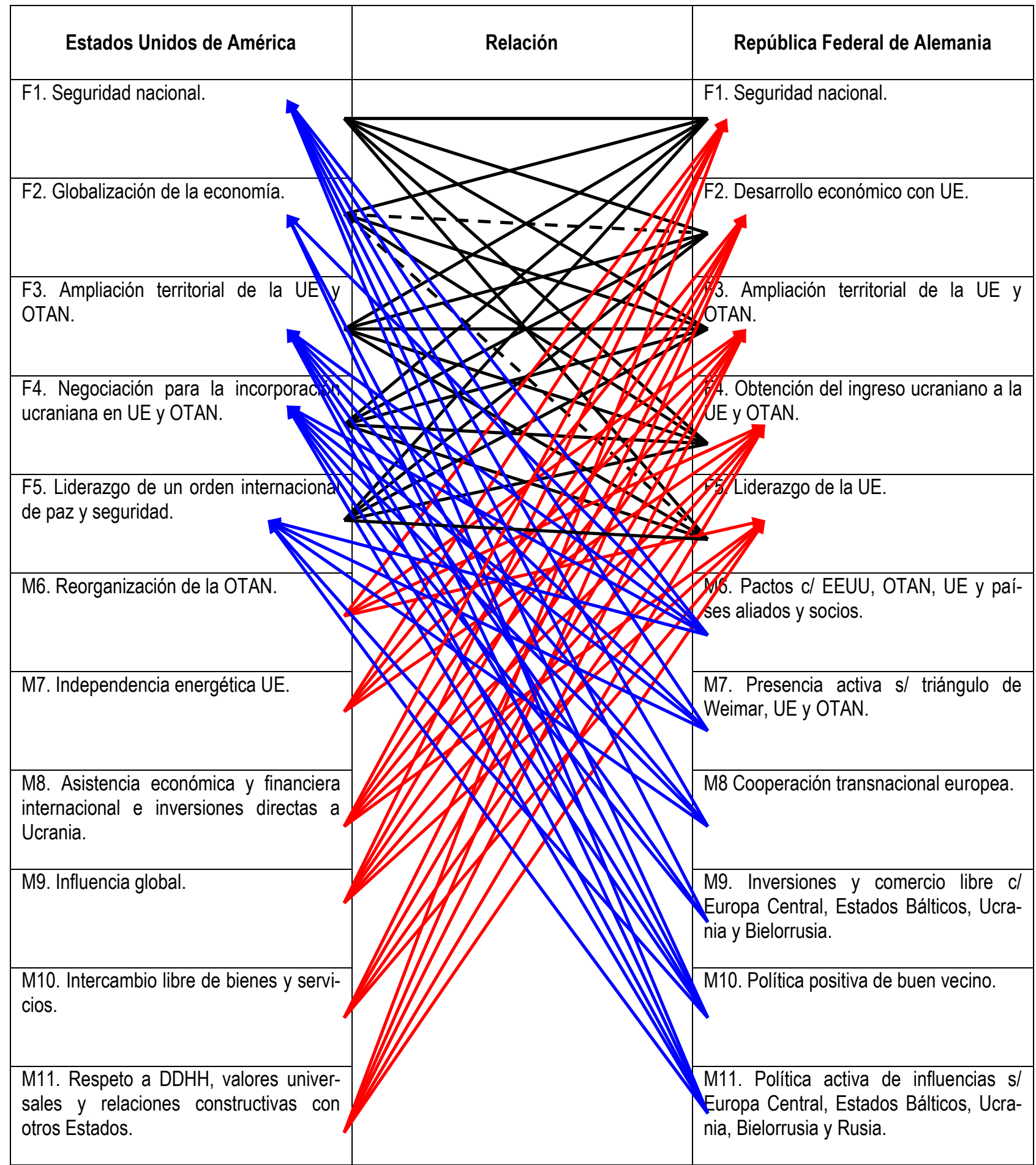

IDENTIFICACIÓN: fines con fines.

PODER: medios a fines.

FUERZA: medios de cambio a medios de cambio. Relación cuantitativa.
Cooperación

Competencia

$\mathrm{Fp} / \mathrm{Fa}$ 
Planilla 32. Relaciones de intereses Estados Unidos de América - República Francesa

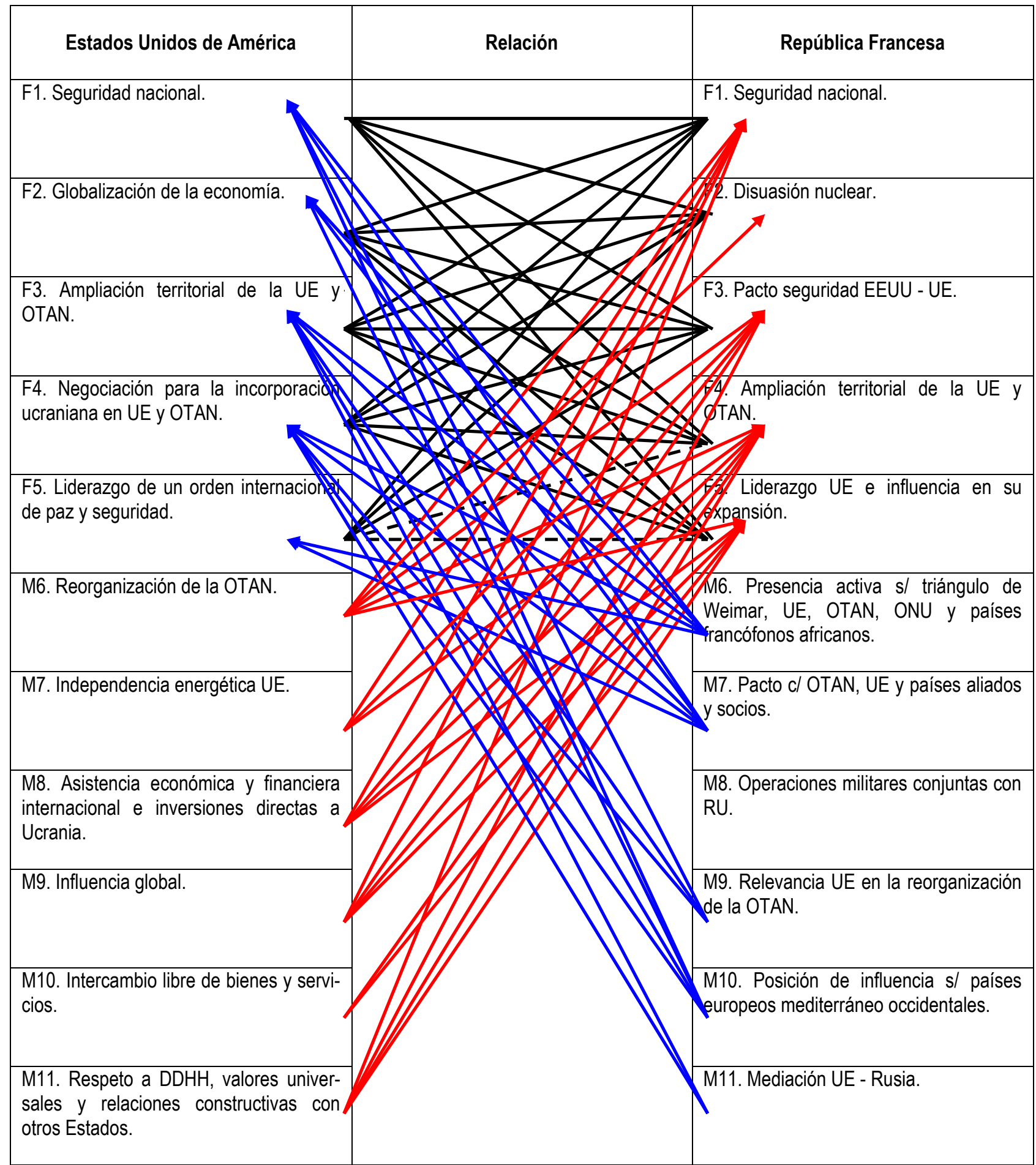

IDENTIFICACIÓN: fines con fines.

PODER: medios a fines.

FUERZA: medios de cambio a medios de cambio. Relación cuantitativa.
Cooperación

Competencia

$\mathrm{Fp} / \mathrm{Fa}$ 
Planilla 33. Relaciones de intereses Estados Unidos de América - República Islámica de Irán

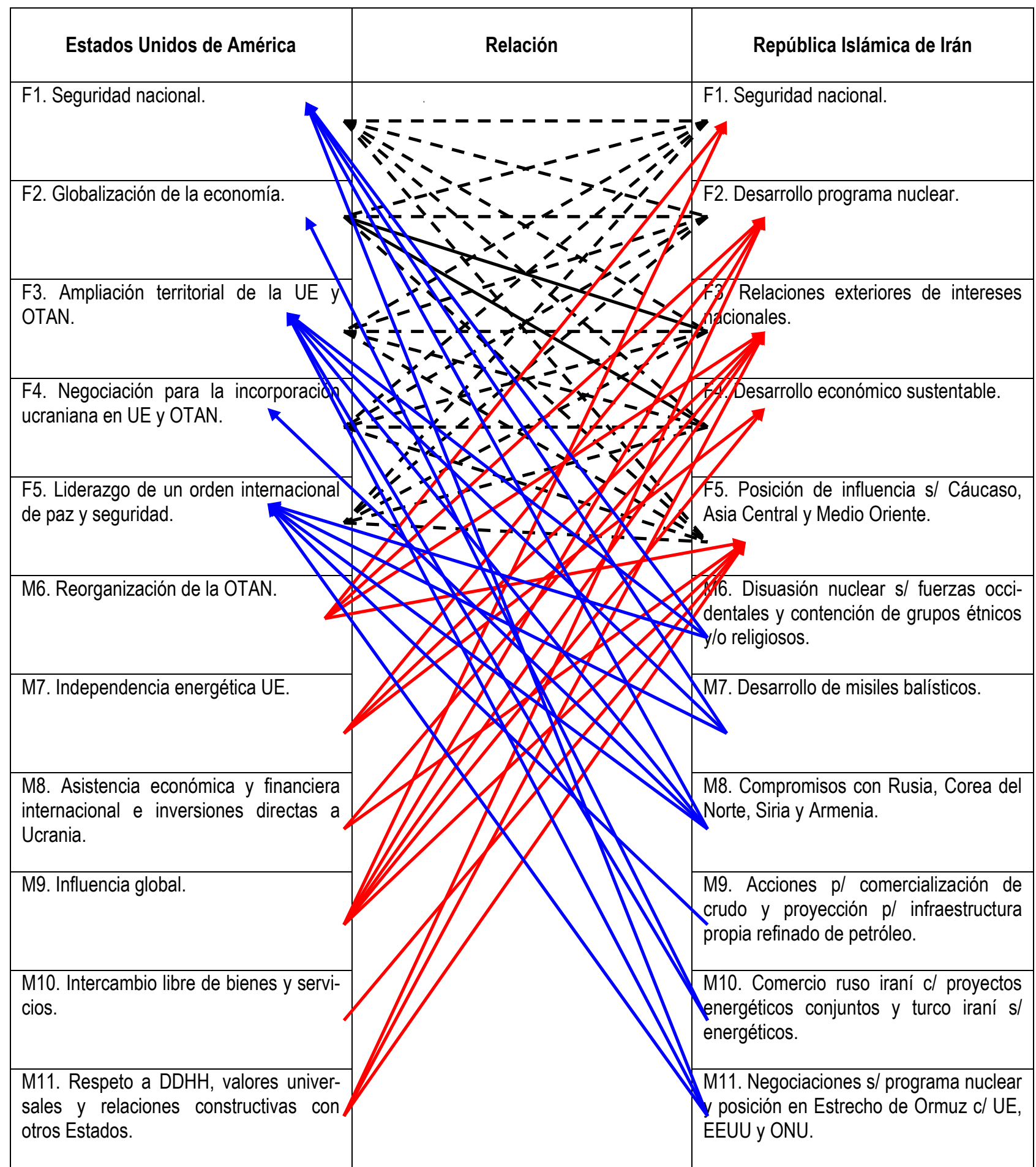

IDENTIFICACIÓN: fines con fines.

PODER: medios a fines.

FUERZA: medios de cambio a medios de cambio. Relación cuantitativa.
Cooperación

Competencia

$\mathrm{Fp} / \mathrm{Fa}$ 
Planilla 34. Relaciones de intereses Estados Unidos de América - República Popular de China

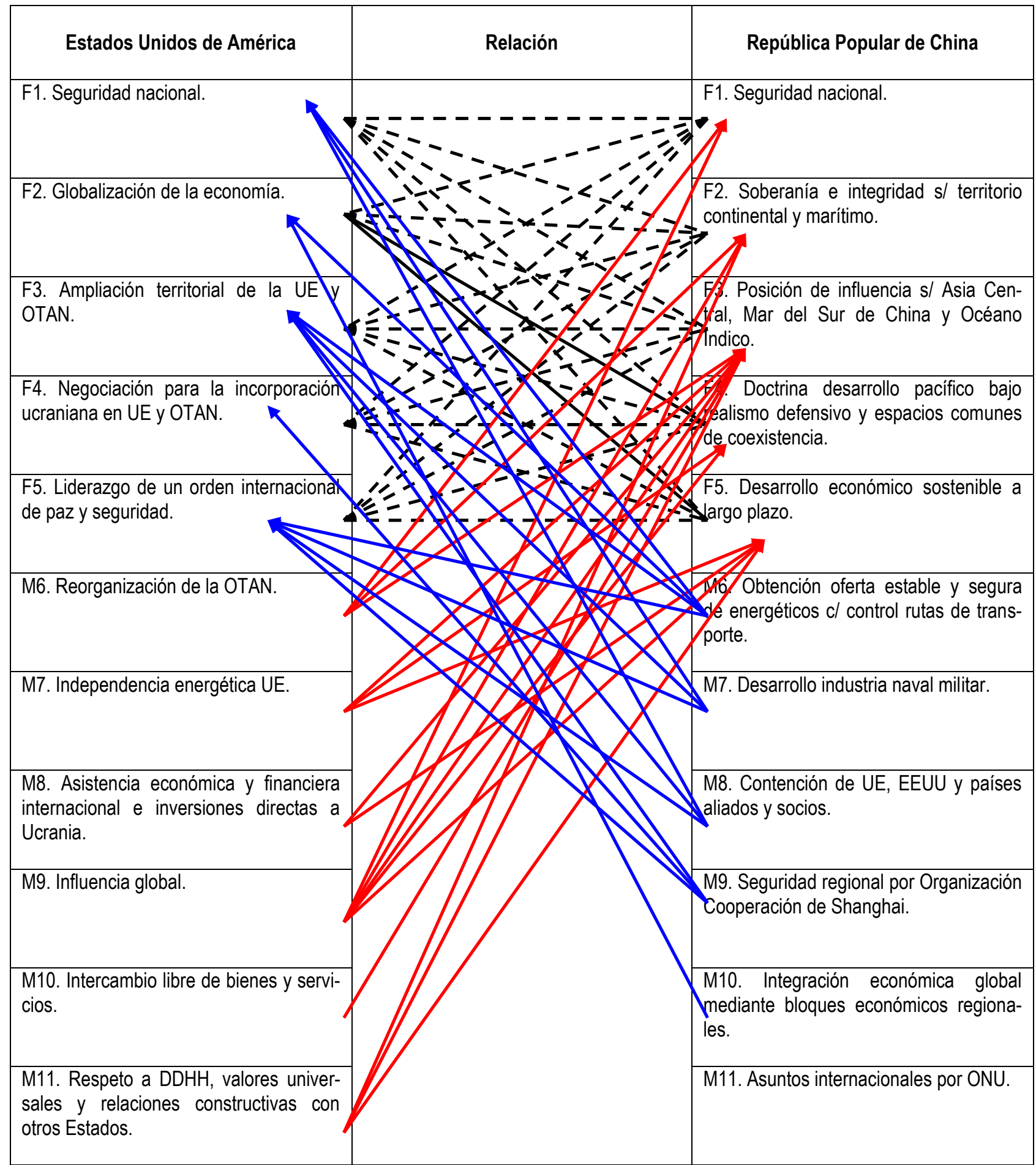

IDENTIFICACIÓN: fines con fines.

PODER: medios a fines.

FUERZA: medios de cambio a medios de cambio. Relación cuantitativa.
Cooperación

Competencia

$\mathrm{Fp} / \mathrm{Fa}$ 
Planilla 35. Relaciones de intereses Reino Unido de Gran Bretaña e Irlanda del Norte - República de Polonia

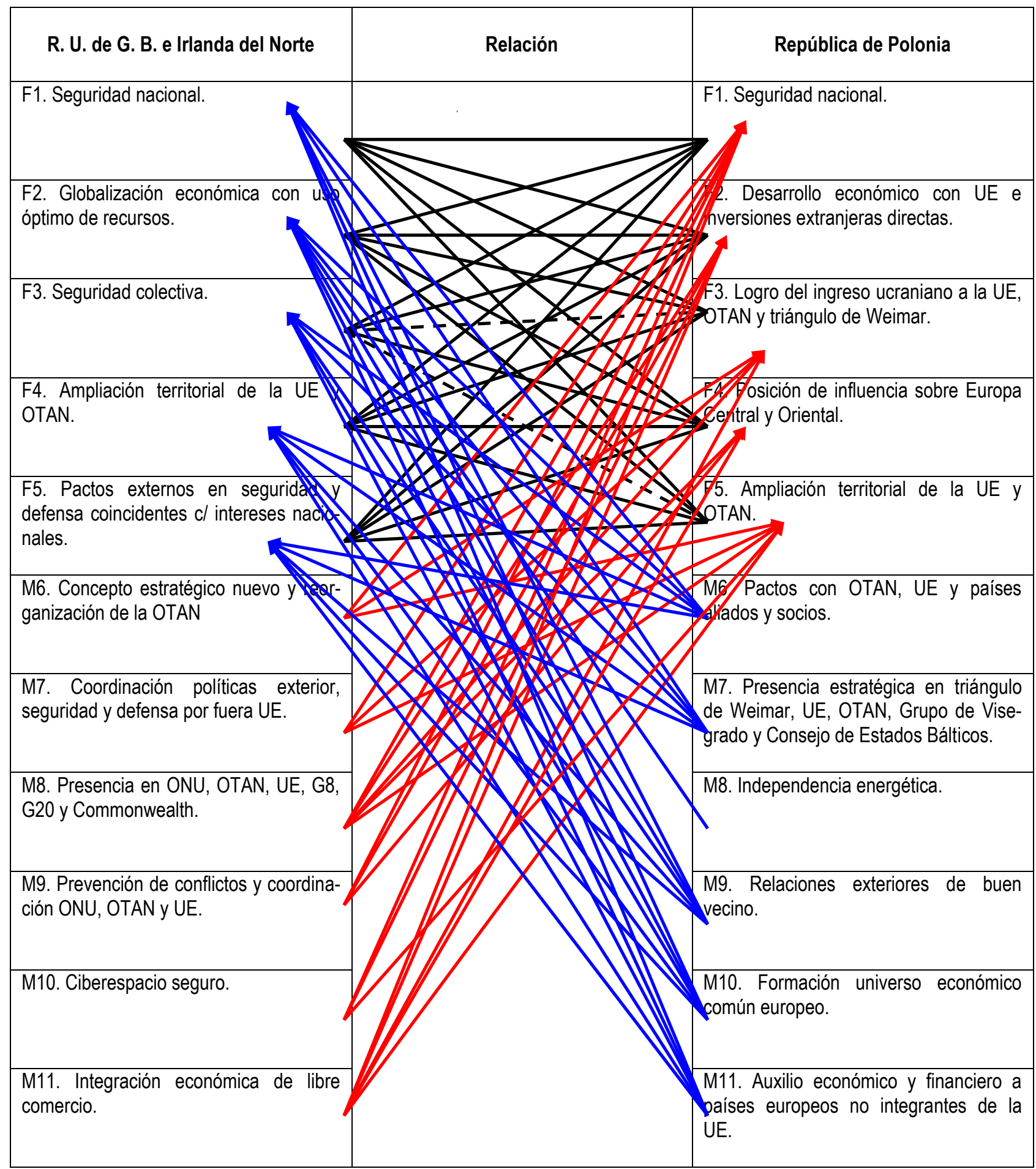

IDENTIFICACIÓN: fines con fines.

PODER: medios a fines.

FUERZA: medios de cambio a medios de cambio. Relación cuantitativa.
Cooperación

Competencia

$\mathrm{Fp} / \mathrm{Fa}$ 
Planilla 36. Relaciones de intereses Reino Unido de Gran Bretaña e Irlanda del Norte - República de Turquía

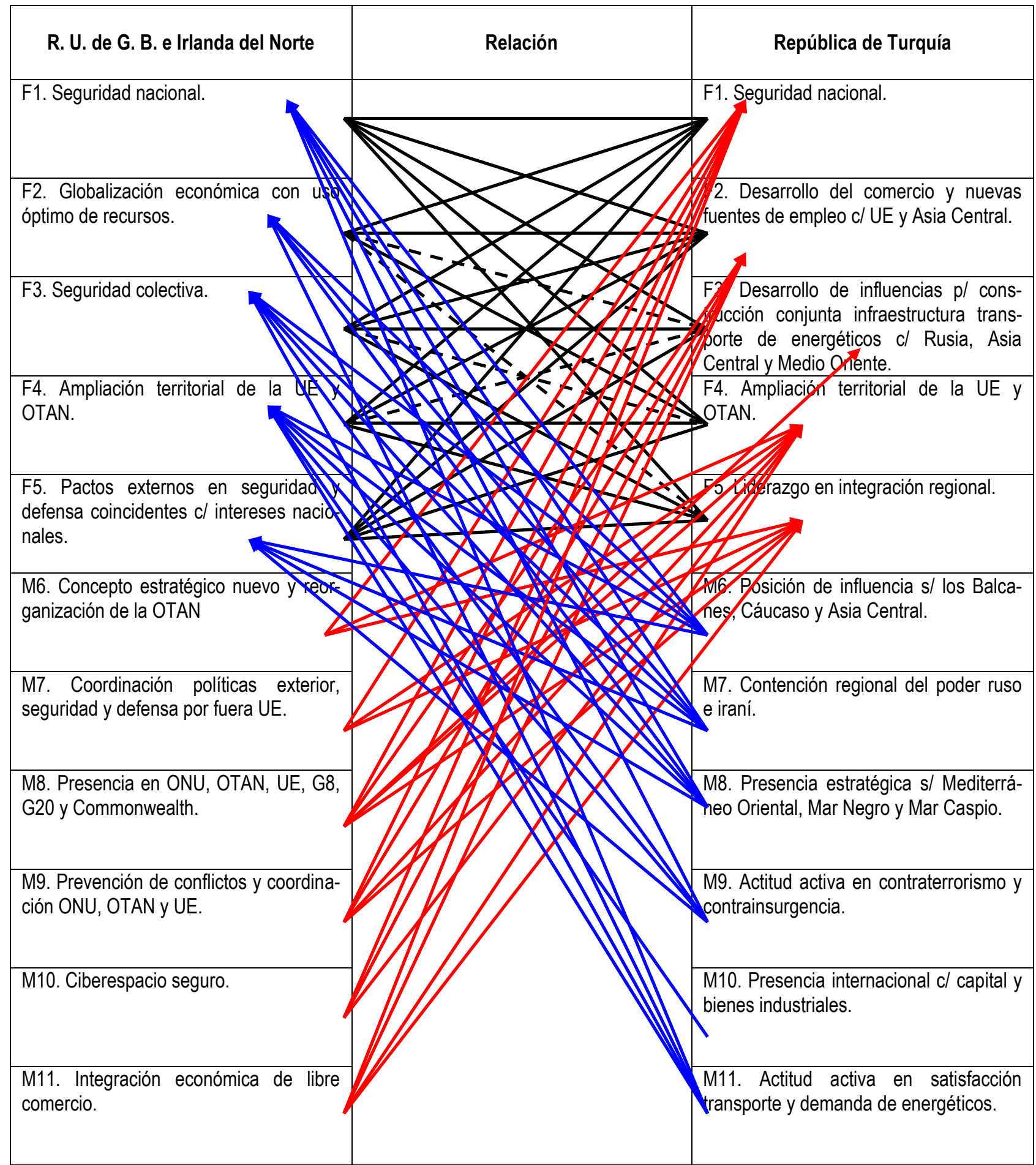

IDENTIFICACIÓN: fines con fines.

PODER: medios a fines.

FUERZA: medios de cambio a medios de cambio. Relación cuantitativa.
Cooperación Competencia

$\mathrm{Fp} / \mathrm{Fa}$ 
Planilla 37. Relaciones de intereses R. U. de G. Bretaña e Irlanda del Norte - República Federal de Alemania

\begin{tabular}{|c|c|c|}
\hline R. U. de G. B. e Irlanda del Norte & Relación & República Federal de Alemania \\
\hline F1. Seguridad nacional. & & F1. Seguridad nacional. \\
\hline $\begin{array}{l}\text { F2. Globalización económica co } \\
\text { óptimo de recursos. }\end{array}$ & & Desarrollo económico con UE. \\
\hline F3. Seguridad colectiva. & & Ampliación territorial de la UE y \\
\hline $\begin{array}{l}\text { F4. Ampliación territorial de la } \\
\text { OTAN. }\end{array}$ & & $\begin{array}{l}\text { 4. Obtención del ingreso ucraniano a la } \\
\text { UE y OTAN. }\end{array}$ \\
\hline $\begin{array}{l}\text { F5. Pactos externos en segu } \\
\text { defensa coincidentes } \mathrm{c} \text { interese }\end{array}$ & & 5. Liderazgo de la UE. \\
\hline $\begin{array}{l}\text { M6. Concepto estratégico nuevo } \\
\text { ganización de la OTAN. }\end{array}$ & & $\begin{array}{l}\text { D. Pactos c/ EEUU, OTAN, UE y paí- } \\
\text { s aliados y socios. }\end{array}$ \\
\hline $\begin{array}{l}\text { M7. Coordinación políticas exte } \\
\text { seguridad y defensa por fuera UE. }\end{array}$ & & $\begin{array}{l}\text { M7. Presencia activa s/ triángulo de } \\
\text { Weimar, UE y OTAN. }\end{array}$ \\
\hline $\begin{array}{l}\text { M8. Presencia en ONU, OTAN, UE, } \\
\text { G20 y Commonwealth. }\end{array}$ & & M8. Cooperación transnacional europea. \\
\hline $\begin{array}{l}\text { M9. Prevención de conflictos y coordi } \\
\text { ción ONU, OTAN y UE. }\end{array}$ & & $\begin{array}{l}\text { M9. Inversiones y comercio libre cl } \\
\text { Europa Central, Estados Bálticos, Ucra- } \\
\text { nia y Bielorrusia. }\end{array}$ \\
\hline M10. Ciberespacio seguro. & & M10. Política positiva de buen vecino. \\
\hline $\begin{array}{l}\text { M11. Integración económica de li } \\
\text { comercio. }\end{array}$ & & $\begin{array}{l}\text { M11. Política activa de influencias s/ } \\
\text { Europa Central, Estados Bálticos, Ucra- } \\
\text { nia, Bielorrusia y Rusia. }\end{array}$ \\
\hline
\end{tabular}

IDENTIFICACIÓN: fines con fines.

PODER: medios a fines.

FUERZA: medios de cambio a medios de cambio. Relación cuantitativa.
Cooperación

Competencia

$\mathrm{Fp} / \mathrm{Fa}$ 
Planilla 38. Relaciones de intereses Reino Unido de Gran Bretaña e Irlanda del Norte - República Francesa

\begin{tabular}{|c|c|c|}
\hline R. U. de G. B. e Irlanda del Norte & Relación & República Francesa \\
\hline F1. Seguridad nacional. & & F1. Seguridad nacional. \\
\hline $\begin{array}{l}\text { F2. Globalización económica c } \\
\text { óptimo de recursos. }\end{array}$ & & Disuasión nuclear. \\
\hline F3. Seguridad colectiva. & & Pacto seguridad EEUU - UE. \\
\hline $\begin{array}{l}\text { F4. Ampliación territorial de la } \\
\text { OTAN. }\end{array}$ & & $\begin{array}{l}\text { 4. Ampliación territorial de la UE y } \\
\text { OTAN. }\end{array}$ \\
\hline $\begin{array}{l}\text { F5. Pactos externos en seg } \\
\text { defensa coincidentes } \mathrm{c} / \text { interes }\end{array}$ & & $\begin{array}{l}\text { Liderazgo UE e influencia en su } \\
\text { pansión. }\end{array}$ \\
\hline $\begin{array}{l}\text { M6. Concepto estratégico nuevo } \\
\text { ganización de la OTAN. }\end{array}$ & & $\begin{array}{l}\text { Presencia activa s/ triángulo de } \\
\text { nar, UE, OTAN, ONU y países }\end{array}$ \\
\hline $\begin{array}{l}\text { M7. Coordinación políticas exter } \\
\text { seguridad y defensa por fuera UE. }\end{array}$ & & $\begin{array}{l}\text { M7. Pactos c/ OTAN, UE y países alia- } \\
\text { dos y socios. }\end{array}$ \\
\hline $\begin{array}{l}\text { M8. Presencia en ONU, OTAN, UE, } \\
\text { G20 y Commonwealth. }\end{array}$ & & $\begin{array}{l}\text { M8. Operaciones militares conjuntas con } \\
\text { RU. }\end{array}$ \\
\hline $\begin{array}{l}\text { M9. Prevención de conflictos y coordi } \\
\text { ción ONU, OTAN y UE. }\end{array}$ & & $\begin{array}{l}\text { M9. Relevancia UE en la reorganización } \\
\text { de la OTAN. }\end{array}$ \\
\hline M10. Ciberespacio seguro. & & M10. Posición de influencia s/ países \\
\hline $\begin{array}{l}\text { M11. Integración económica de li } \\
\text { comercio. }\end{array}$ & & M11. Mediación UE - Rusia. \\
\hline
\end{tabular}

IDENTIFICACIÓN: fines con fines.

PODER: medios a fines.

FUERZA: medios de cambio a medios de cambio. Relación cuantitativa.
Cooperación

Competencia

$\mathrm{Fp} / \mathrm{Fa}$ 
Planilla 39. Relaciones de intereses R. U. de Gran Bretaña e Irlanda del Norte - República Islámica de Irán

\begin{tabular}{|c|c|c|}
\hline R. U. de G. B. e Irlanda del Norte & Relación & República Islámica de Irán \\
\hline F1. Seguridad nacional. & & F1. Seguridad nacional. \\
\hline $\begin{array}{l}\text { F2. Globalización económica con } \\
\text { óptimo de recursos. }\end{array}$ & & F2. Desarrollo programa nuclear. \\
\hline F3. Seguridad colectiva. & & F3. Relaciones exteriores de intereses \\
\hline $\begin{array}{l}\text { F4. Ampliación territorial de la } \mathrm{L} \\
\text { OTAN. }\end{array}$ & & 4. Desarrollo económico sustentable. \\
\hline $\begin{array}{l}\text { F5. Pactos externos en seguridad } \\
\text { defensa coincidentes } \mathrm{c} / \text { intereses nac } \\
\text { nales. }\end{array}$ & & $\begin{array}{l}\text { 5. Posición de influencia s/ Cáucaso, } \\
\text { Asia Central y Medio Oriente. }\end{array}$ \\
\hline $\begin{array}{l}\text { M6. Concepto estratégico nuevo y } \\
\text { ganización de la OTAN. }\end{array}$ & & $\begin{array}{l}\text { 6. Disuasión nuclear s/ fuerzas occi- } \\
\text { entales y contención de grupos étnicos }\end{array}$ \\
\hline $\begin{array}{l}\text { M7. Coordinación políticas exterii } \\
\text { seguridad y defensa por fuera UE. }\end{array}$ & & 7. Desarrollo de misiles balísticos. \\
\hline $\begin{array}{l}\text { M8. Presencia en ONU, OTAN, UE, G } \\
\text { G20 y Commonwealth. }\end{array}$ & & $\begin{array}{l}\text { M8. Pactos con Rusia, Corea del Norte, } \\
\text { Siria y Armenia. }\end{array}$ \\
\hline $\begin{array}{l}\text { M9. Prevención de conflictos y coordin } \\
\text { ción ONU con OTAN y UE. }\end{array}$ & & $\begin{array}{l}\text { M9. Acciones } \mathrm{p} / \text { comercialización de } \\
\text { Crudo y proyección } \mathrm{p} / \text { infraestructura } \\
\text { propia refinado de petróleo. }\end{array}$ \\
\hline M10. Ciberespacio seguro. & & $\begin{array}{l}\text { M10. Comercio ruso iraní } \mathrm{c} \text { proyectos } \\
\text { energéticos conjuntos y turco iraní } \mathrm{s} / \\
\text { energéticos. }\end{array}$ \\
\hline $\begin{array}{l}\text { M11. Integración económica de lib } \\
\text { comercio. }\end{array}$ & & $\begin{array}{l}\text { M11. Negociaciones s/ programa nuclear } \\
\text { y posición en Estrecho de Ormuz c/ UE, } \\
\text { EEUU y ONU. }\end{array}$ \\
\hline
\end{tabular}

IDENTIFICACIÓN: fines con fines.

PODER: medios a fines.

FUERZA: medios de cambio a medios de cambio. Relación cuantitativa.
Cooperación

Competencia

$\mathrm{Fp} / \mathrm{Fa}$ 
Planilla 40. Relaciones de intereses R. U. de Gran Bretaña e Irlanda del Norte - República Popular de China

\begin{tabular}{|c|c|c|}
\hline R. U. de G. B. e Irlanda del Norte & Relación & República Popular de China \\
\hline F1. Seguridad nacional. & & F1. Seguridad nacional. \\
\hline $\begin{array}{l}\text { F2. Globalización económica con } \\
\text { óptimo de recursos. }\end{array}$ & & $\begin{array}{l}\text { F2. Soberanía e integridad s/ territorio } \\
\text { continental y marítimo. }\end{array}$ \\
\hline F3. Seguridad colectiva. & & F3. Posición de influencia s/ Asia Cen- \\
\hline $\begin{array}{l}\text { F4. Ampliación territorial de la UE } \\
\text { OTAN. }\end{array}$ & & $\begin{array}{l}\text { 4. Doctrina desarrollo pacífico bajo } \\
\text { realismo defensivo y espacios comunes }\end{array}$ \\
\hline $\begin{array}{l}\text { F5. Pactos externos en seguridad } \\
\text { defensa coincidentes } \mathrm{c} / \text { intereses naci }\end{array}$ & & $\begin{array}{l}\text { 5. Desarrollo económico sostenible a } \\
\text { largo plazo. }\end{array}$ \\
\hline $\begin{array}{l}\text { M6. Concepto estratégico nuevo y rec } \\
\text { ganización de la OTAN. }\end{array}$ & & $\begin{array}{l}\text { M6. Obtención oferta estable y segura } \\
\text { de energéticos } \mathrm{cl} \text { control rutas de trans- }\end{array}$ \\
\hline $\begin{array}{l}\text { M7. Coordinación políticas exteric } \\
\text { seguridad y defensa por fuera UE. }\end{array}$ & & Desarrollo industria naval militar. \\
\hline $\begin{array}{l}\text { M8. Presencia en ONU, OTAN, UE, G } \\
\text { G20 y Commonwealth. }\end{array}$ & & $\begin{array}{l}\text { M8. Contención de UE, EEUU y países } \\
\text { aliados y socios. }\end{array}$ \\
\hline $\begin{array}{l}\text { M9. Prevención de conflictos y coordin } \\
\text { ción ONU con OTAN y UE. }\end{array}$ & & $\begin{array}{l}\text { M9. Seguridad regional por Organización } \\
\text { de Cooperación de Shanghai. }\end{array}$ \\
\hline M10. Ciberespacio seguro. & & $\begin{array}{l}\text { M10. Integración económica global } \\
\text { mediante bloques económicos regiona- } \\
\text { les. }\end{array}$ \\
\hline $\begin{array}{l}\text { M11. Integración económica de lib } \\
\text { comercio. }\end{array}$ & & M11. Asuntos internacionales por ONU. \\
\hline
\end{tabular}

IDENTIFICACIÓN: fines con fines.

PODER: medios a fines.

FUERZA: medios de cambio a medios de cambio. Relación cuantitativa.
Cooperación

Competencia

$\mathrm{Fp} / \mathrm{Fa}$ 
Planilla 41. Relaciones de intereses República de Polonia - República de Turquía

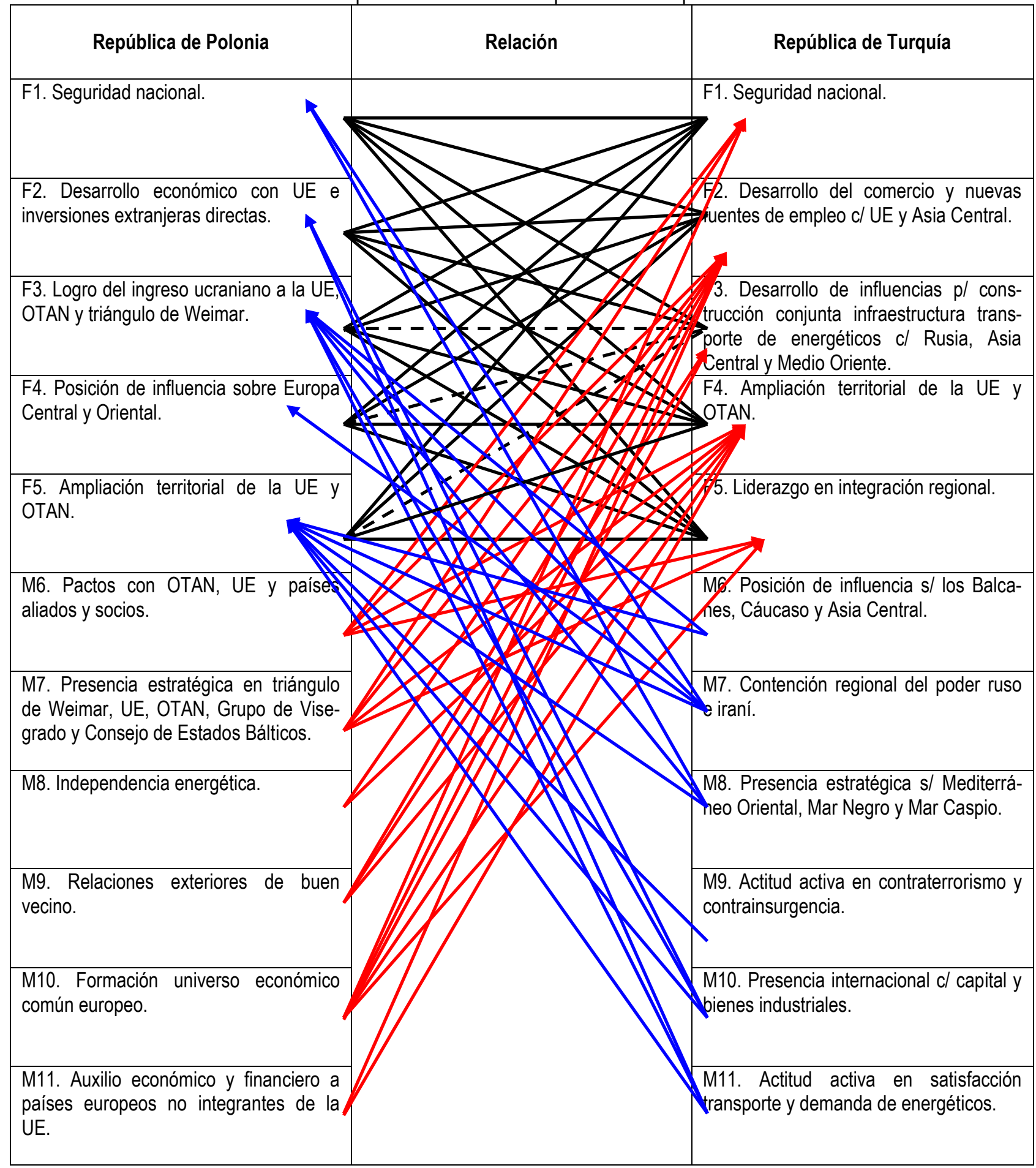

IDENTIFICACIÓN: fines con fines.

PODER: medios a fines.

FUERZA: medios de cambio a medios de cambio. Relación cuantitativa.
Cooperación

Competencia

$\mathrm{Fp} / \mathrm{Fa}$ 
Planilla 42. Relaciones de intereses República de Polonia - República Federal de Alemania

\begin{tabular}{|c|c|c|}
\hline República de Polonia & Relación & República Federal de Alemania \\
\hline F1. Seguridad nacional. & & F1. Seguridad nacional. \\
\hline $\begin{array}{l}\text { F2. Desarrollo económico con UE } \\
\text { inversiones extranjeras directas. }\end{array}$ & & Desarrollo económico con UE. \\
\hline $\begin{array}{l}\text { F3. Logro del ingreso ucraniano a la UE, } \\
\text { OTAN y triángulo de Weimar. }\end{array}$ & & $\begin{array}{l}\text { Ampliación territorial de la UE y } \\
\text { N. }\end{array}$ \\
\hline $\begin{array}{l}\text { F4. Posición de influencia sobre Europa } \\
\text { Central y Oriental. }\end{array}$ & & $\begin{array}{l}\text { Obtención del ingreso ucraniano a la } \\
\text { y OTAN. }\end{array}$ \\
\hline $\begin{array}{l}\text { F5. Ampliación territorial de la UE } \\
\text { OTAN. }\end{array}$ & & 5. Liderazgo de la UE. \\
\hline $\begin{array}{l}\text { M6. Pactos con OTAN, UE y pais } \\
\text { aliados y socios. }\end{array}$ & & $\begin{array}{l}\text { M6. Pactos c/ EEUU, OTAN, UE y paí- } \\
\text { ses aliados y socios. }\end{array}$ \\
\hline $\begin{array}{l}\text { M7. Presencia estratégica en triángulo } \\
\text { de Weimar, UE, OTAN, Grupo de Vise- } \\
\text { grado y Consejo de Estados Bálticos. }\end{array}$ & & $\begin{array}{l}\text { M7. Presencia activa s/ triángulo de } \\
\text { Weimar, UE y OTAN. }\end{array}$ \\
\hline M8. Independencia energética. & & M8. Cooperación transnacional europea. \\
\hline $\begin{array}{l}\text { M9. Relaciones exteriores de buen } \\
\text { vecino. }\end{array}$ & & $\begin{array}{l}\text { M9. Inversiones y comercio libre cl } \\
\text { Europa Central, Estados Bálticos, Ucra- } \\
\text { nia y Bielorrusia. }\end{array}$ \\
\hline $\begin{array}{l}\text { M10. Formación universo económico } \\
\text { común europeo. }\end{array}$ & & M10. Política positiva de buen vecino. \\
\hline $\begin{array}{l}\text { M11. Auxilio económico y financiero a } \\
\text { países europeos no integrantes de la } \\
\text { UE. }\end{array}$ & & $\begin{array}{l}\text { M11. Política activa de influencias s/ } \\
\text { Europa Central, Estados Bálticos, Ucra- } \\
\text { nia, Bielorrusia y Rusia. }\end{array}$ \\
\hline
\end{tabular}

IDENTIFICACIÓN: fines con fines.

PODER: medios a fines.

FUERZA: medios de cambio a medios de cambio. Relación cuantitativa.
Cooperación

Competencia

$\mathrm{Fp} / \mathrm{Fa}$ 
Planilla 43. Relaciones de intereses República de Polonia - República Francesa

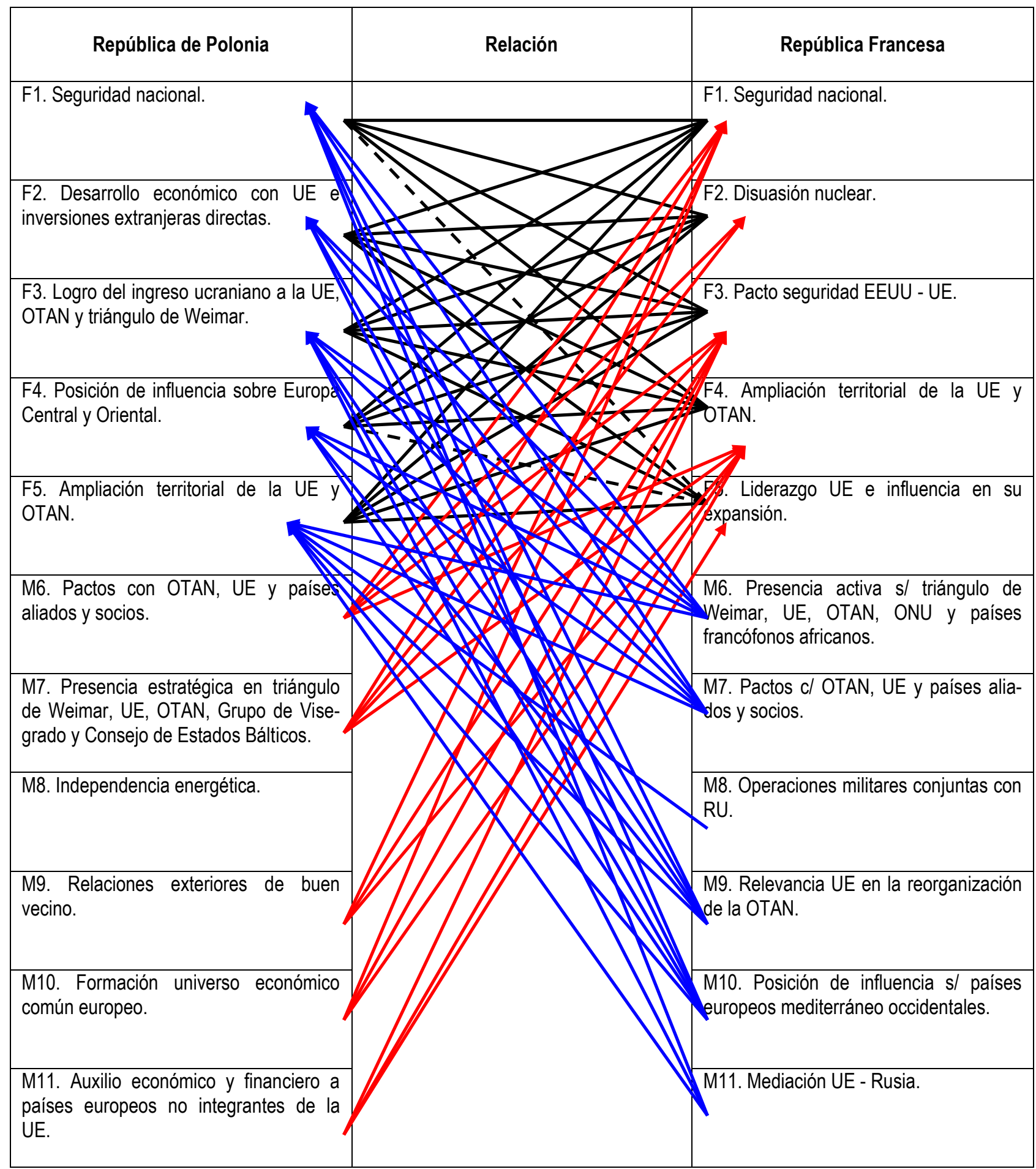

IDENTIFICACIÓN: fines con fines.

PODER: medios a fines.

FUERZA: medios de cambio a medios de cambio. Relación cuantitativa.
Cooperación

Competencia

$\mathrm{Fp} / \mathrm{Fa}$ 
Planilla 44. Relaciones de intereses República de Polonia - República Islámica de Irán

\begin{tabular}{|c|c|c|}
\hline República de Polonia & Relación & República Islámica de Irán \\
\hline F1. Seguridad nacional. & & F1. Seguridad nacional. \\
\hline $\begin{array}{l}\text { F2. Desarrollo económico con UE } \\
\text { inversiones extranjeras directas. }\end{array}$ & & F2. Desarrollo programa nuclear. \\
\hline $\begin{array}{l}\text { F3. Logro del ingreso ucraniano a la UE, } \\
\text { OTAN y triángulo de Weimar. }\end{array}$ & & $\begin{array}{l}\text { Relaciones exteriores de intereses } \\
\text { nales. }\end{array}$ \\
\hline $\begin{array}{l}\text { F4. Posición de influencia sobre Europa } \\
\text { Central y Oriental. }\end{array}$ & & Desarrollo económico sustentable. \\
\hline $\begin{array}{l}\text { F5. Ampliación territorial de la UE y } \\
\text { OTAN. }\end{array}$ & & $\begin{array}{l}\text { 5. Posición de influencia s/ Cáucaso, } \\
\text { Asia Central y Medio Oriente. }\end{array}$ \\
\hline $\begin{array}{l}\text { M6. Pactos con OTAN, UE y países } \\
\text { aliados y socios. }\end{array}$ & & $\begin{array}{l}\text { Disuasión nuclear s/ fuerzas occi- } \\
\text { tales y contención de grupos étnicos }\end{array}$ \\
\hline $\begin{array}{l}\text { M7. Presencia estratégica en triángulo } \\
\text { de Weimar, UE, OTAN, Grupo de Vise- } \\
\text { grado y Consejo de Estados Bálticos. }\end{array}$ & & M7. Desarrollo de misiles balísticos. \\
\hline M8. Independencia energética. & & M8. Pactos con Rusia, Corea del Norte, \\
\hline $\begin{array}{l}\text { M9. Relaciones exteriores de buen } \\
\text { vecino. }\end{array}$ & & $\begin{array}{l}\text { M9. Acciones } \mathrm{p} / \text { comercialización de } \\
\text { crudo y proyección } \mathrm{p} / \text { infraestructura } \\
\text { propia refinado de petróleo. }\end{array}$ \\
\hline $\begin{array}{l}\text { M10. Formación universo económico } \\
\text { común europeo. }\end{array}$ & & $\begin{array}{l}\text { M10. Comercio ruso iraní c/ proyectos } \\
\text { energéticos conjuntos y turco iraní s/ } \\
\text { energéticos. }\end{array}$ \\
\hline $\begin{array}{l}\text { M11. Auxilio económico y financiero a } \\
\text { países europeos no integrantes de la } \\
\text { UE. }\end{array}$ & & $\begin{array}{l}\text { M11. Negociaciones s/ programa nuclear } \\
\text { posición en Estrecho de Ormuz c/ UE, } \\
\text { EEUU y ONU. }\end{array}$ \\
\hline
\end{tabular}

IDENTIFICACIÓN: fines con fines.

PODER: medios a fines.

FUERZA: medios de cambio a medios de cambio. Relación cuantitativa.
Cooperación

Competencia

$\mathrm{Fp} / \mathrm{Fa}$ 
Planilla 45. Relaciones de intereses República de Polonia - República Popular de China

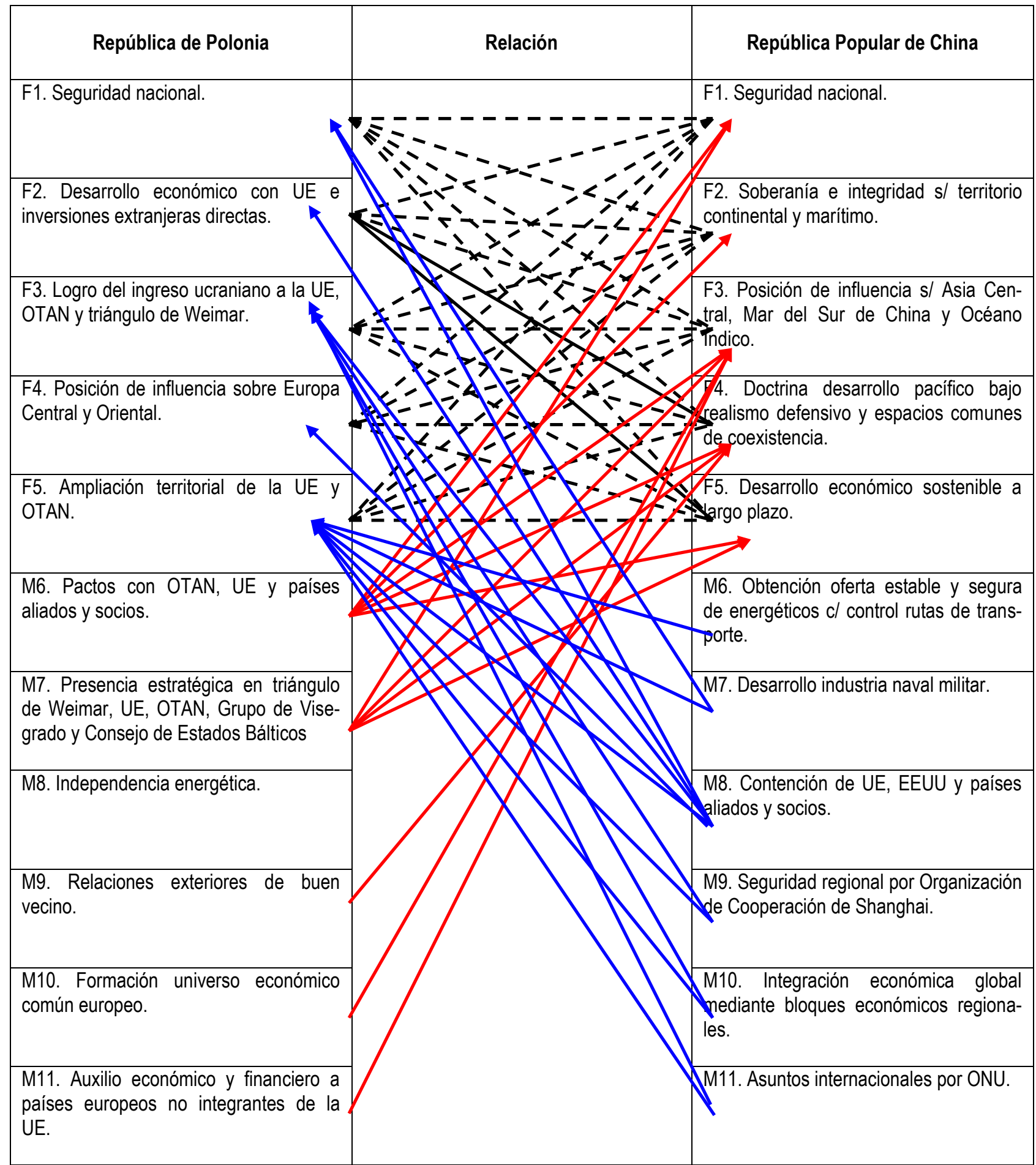

IDENTIFICACIÓN: fines con fines.

PODER: medios a fines.

FUERZA: medios de cambio a medios de cambio. Relación cuantitativa.
Cooperación

Competencia

$\mathrm{Fp} / \mathrm{Fa}$ 
Planilla 46. Relaciones de intereses República de Turquía - República Federal de Alemania

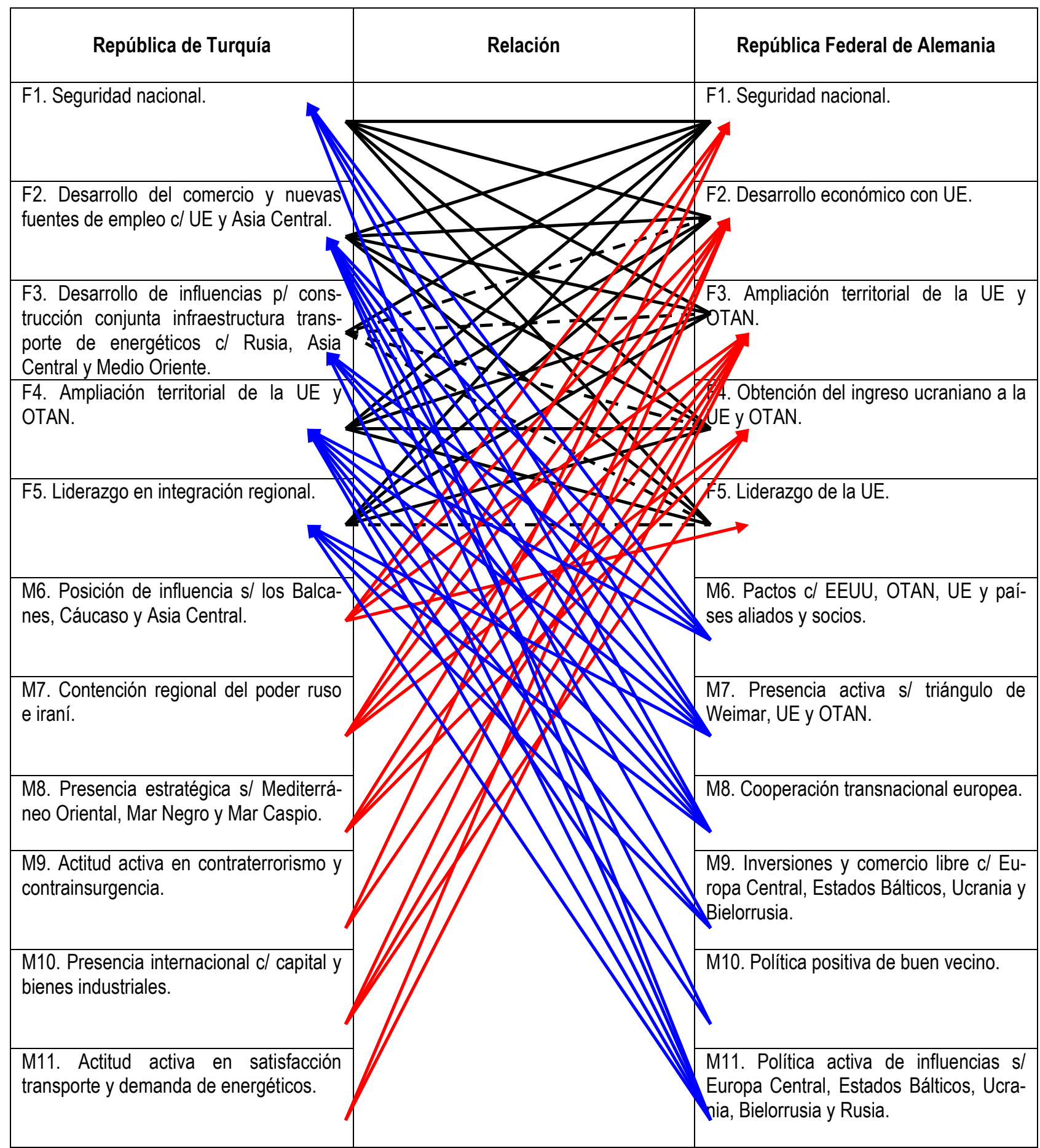

IDENTIFICACIÓN: fines con fines.

PODER: medios a fines.

FUERZA: medios de cambio a medios de cambio. Relación cuantitativa.
Cooperación

Competencia

$\mathrm{Fp} / \mathrm{Fa}$ 
Planilla 47. Relaciones de intereses República de Turquía - República Francesa

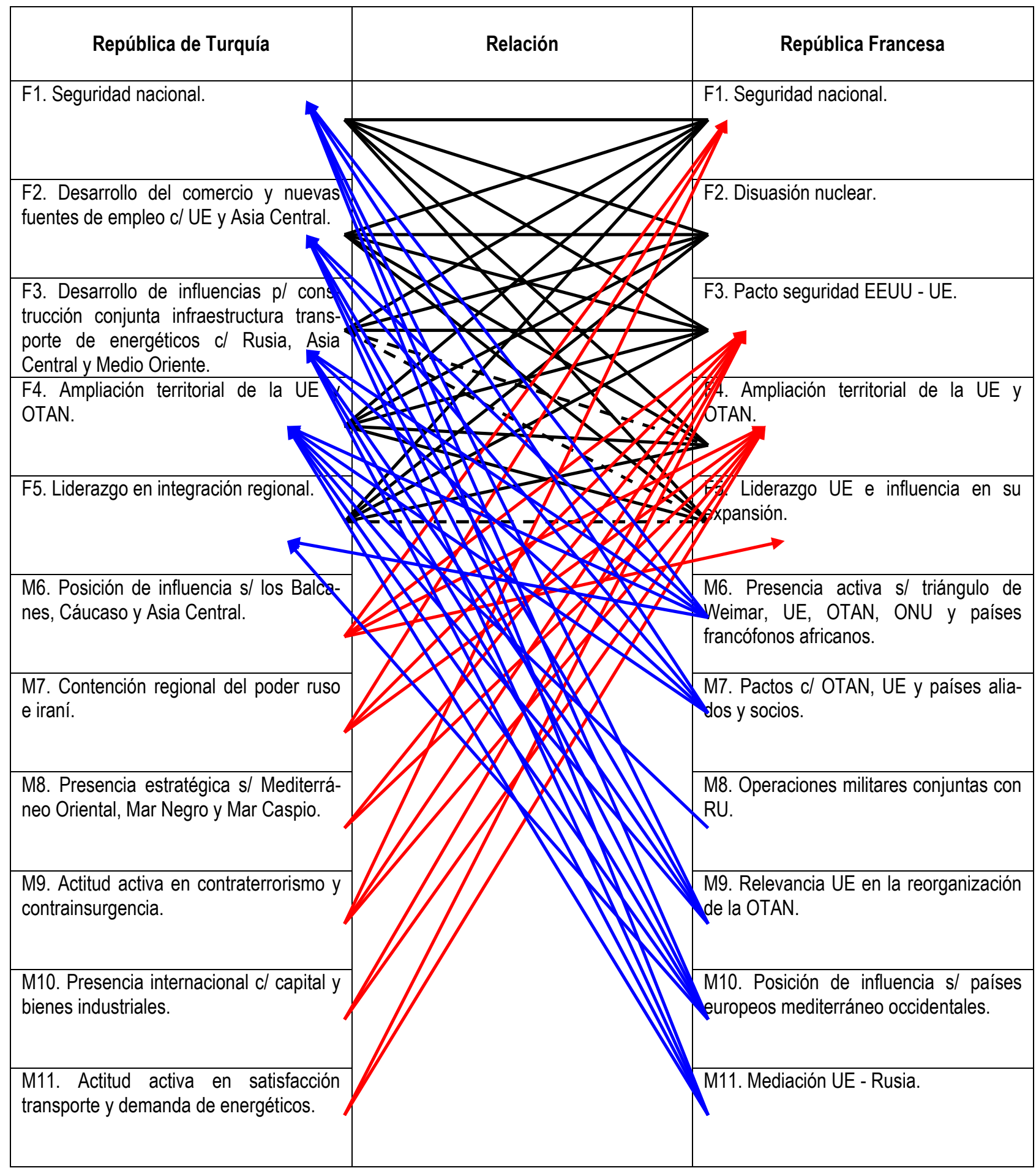

IDENTIFICACIÓN: fines con fines.

PODER: medios a fines.

FUERZA: medios de cambio a medios de cambio. Relación cuantitativa.
Cooperación

Competencia

$\mathrm{Fp} / \mathrm{Fa}$ 
Planilla 48. Relaciones de intereses República de Turquía - República Islámica de Irán

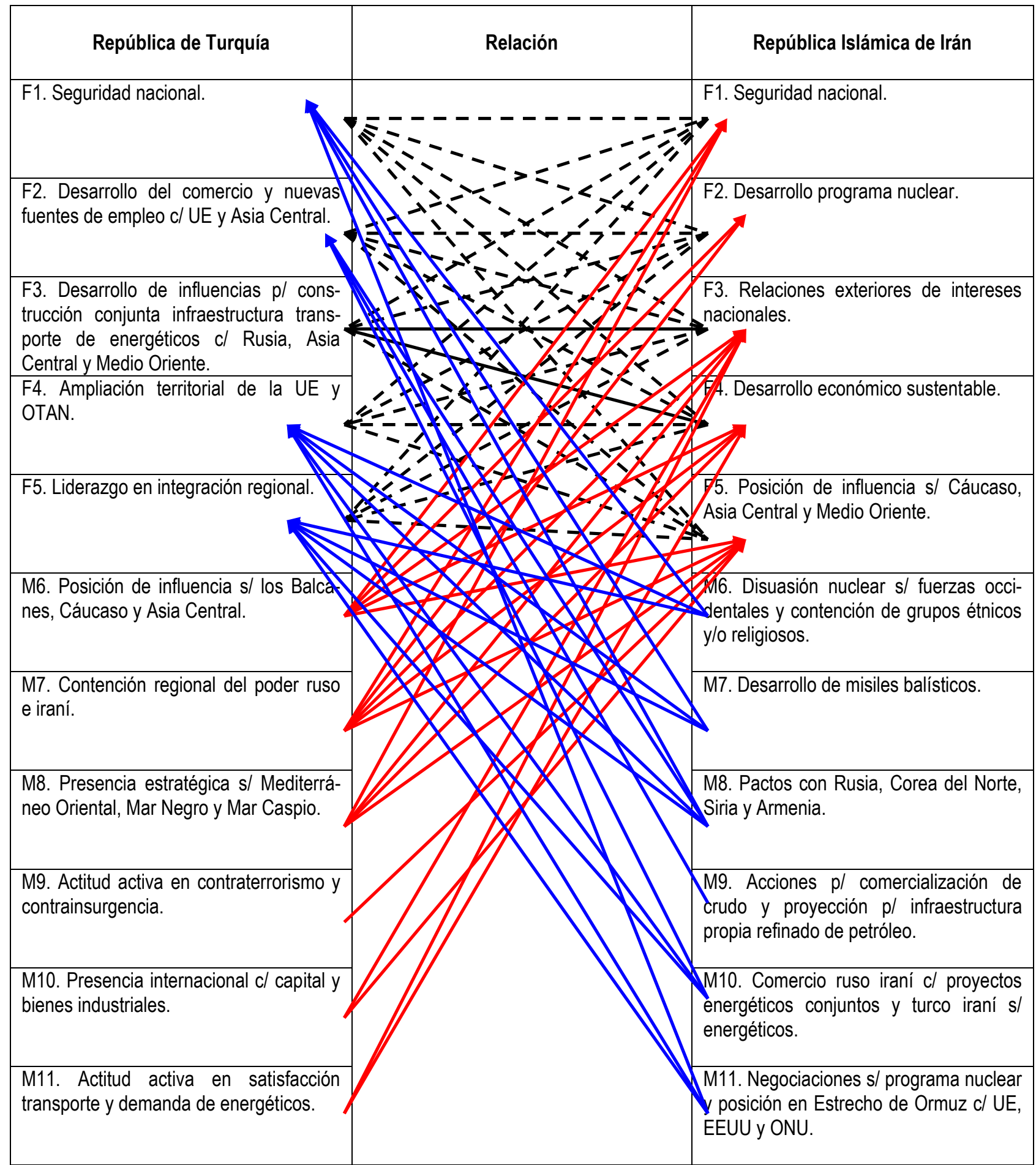

IDENTIFICACIÓN: fines con fines.

PODER: medios a fines.

FUERZA: medios de cambio a medios de cambio. Relación cuantitativa.
Cooperación

Competencia

$\mathrm{Fp} / \mathrm{Fa}$ 
Planilla 49. Relaciones de intereses República de Turquía - República Popular de China

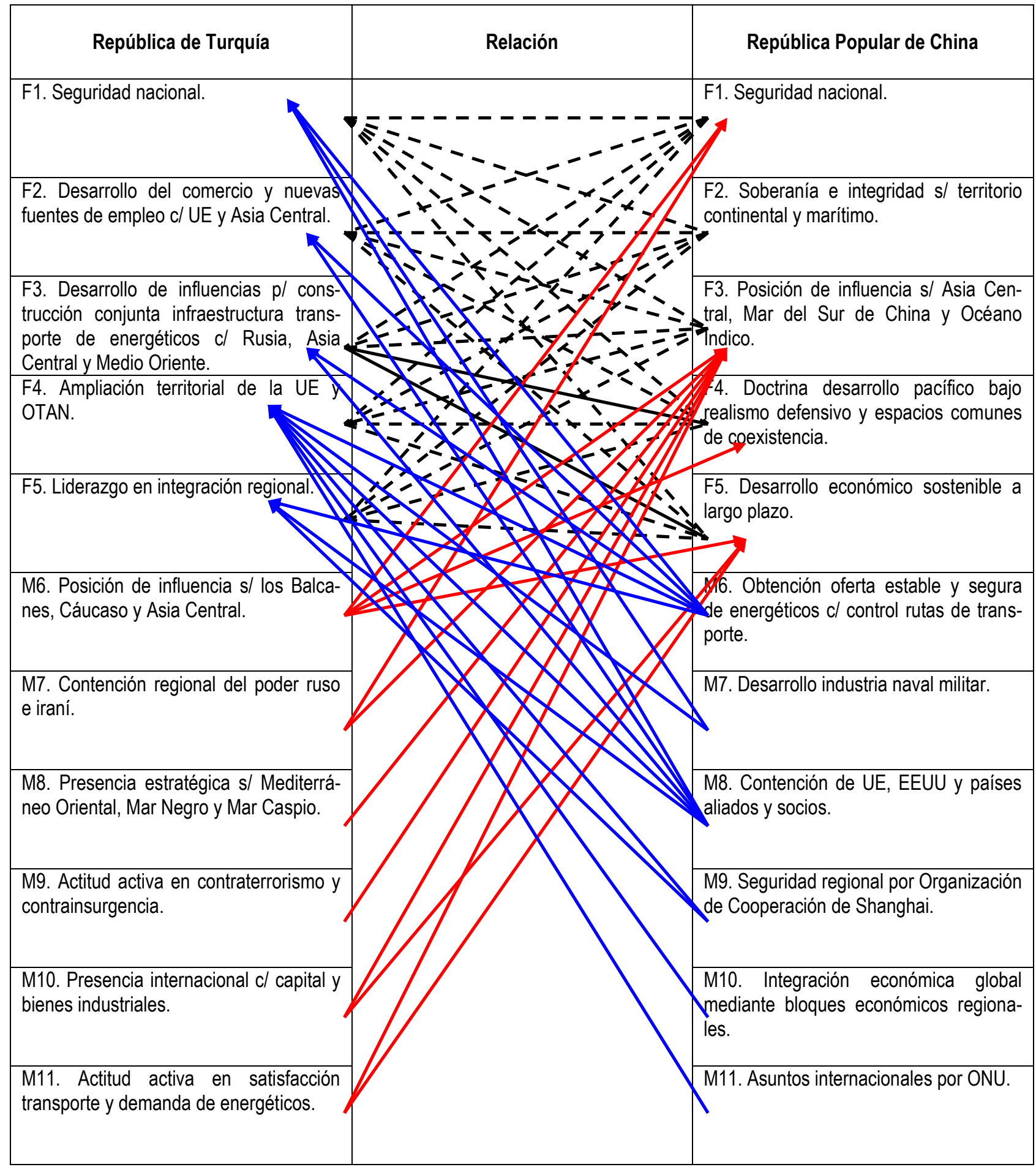

IDENTIFICACIÓN: fines con fines.

PODER: medios a fines.

FUERZA: medios de cambio a medios de cambio. Relación cuantitativa.
Cooperación

Competencia

$\mathrm{Fp} / \mathrm{Fa}$ 
Planilla 50. Relaciones de intereses República Federal de Alemania - República Francesa

\begin{tabular}{|c|c|c|}
\hline República Federal de Alemania & Relación & República Francesa \\
\hline F1. Seguridad nacional. & & F1. Seguridad nacional. \\
\hline F2. Desarrollo económico con UE. & & Disuasión nuclear. \\
\hline $\begin{array}{l}\text { F3. Ampliación territorial de la } \\
\text { OTAN. }\end{array}$ & & acto seguridad EEUU - UE. \\
\hline $\begin{array}{l}\text { F4. Obtención del ingreso ucraniano a } \\
\text { UE y OTAN. }\end{array}$ & & $\begin{array}{l}\text { 4. Ampliación territorial de la UE y } \\
\text { OTAN. }\end{array}$ \\
\hline F5. Liderazgo de la UE. & & 5. Liderazgo UE e influencia en su \\
\hline $\begin{array}{l}\text { M6. Pactos c/ EEUU, OTAN, UE y } \mathrm{p} \\
\text { ses aliados y socios. }\end{array}$ & & $\begin{array}{l}\text { Presencia activa s/ triángulo de } \\
\text { mar, UE, OTAN, ONU y países }\end{array}$ \\
\hline $\begin{array}{l}\text { M7. Presencia activa s/ triángulo } \\
\text { Weimar, UE y OTAN. }\end{array}$ & & $\begin{array}{l}\text { M7. Pactos c/ OTAN, UE y países alia- } \\
\text { dos y socios. }\end{array}$ \\
\hline M8. Cooperación transnacional europ & & M8. Operaciones militares conjuntas con \\
\hline $\begin{array}{l}\text { M9. Inversiones y comercio libre } \\
\text { Europa Central, Estados Bálticos, Uc }\end{array}$ & & $\begin{array}{l}\text { M9. Relevancia UE en la reorganización } \\
\text { de la OTAN. }\end{array}$ \\
\hline M10. Política positiva de buen vecino. & & M10. Posición de influencia s/ países \\
\hline $\begin{array}{l}\text { M11. Política activa de influencias } \\
\text { Europa Central, Estados Bálticos, Uc } \\
\text { nia, Bielorrusia y Rusia. }\end{array}$ & & M11. Mediación UE - Rusia. \\
\hline
\end{tabular}

IDENTIFICACIÓN: fines con fines.

PODER: medios a fines.

FUERZA: medios de cambio a medios de cambio. Relación cuantitativa.
Cooperación Competencia

$\mathrm{Fp} / \mathrm{Fa}$ 
Planilla 51. Relaciones de intereses República Federal de Alemania - República Islámica de Irán

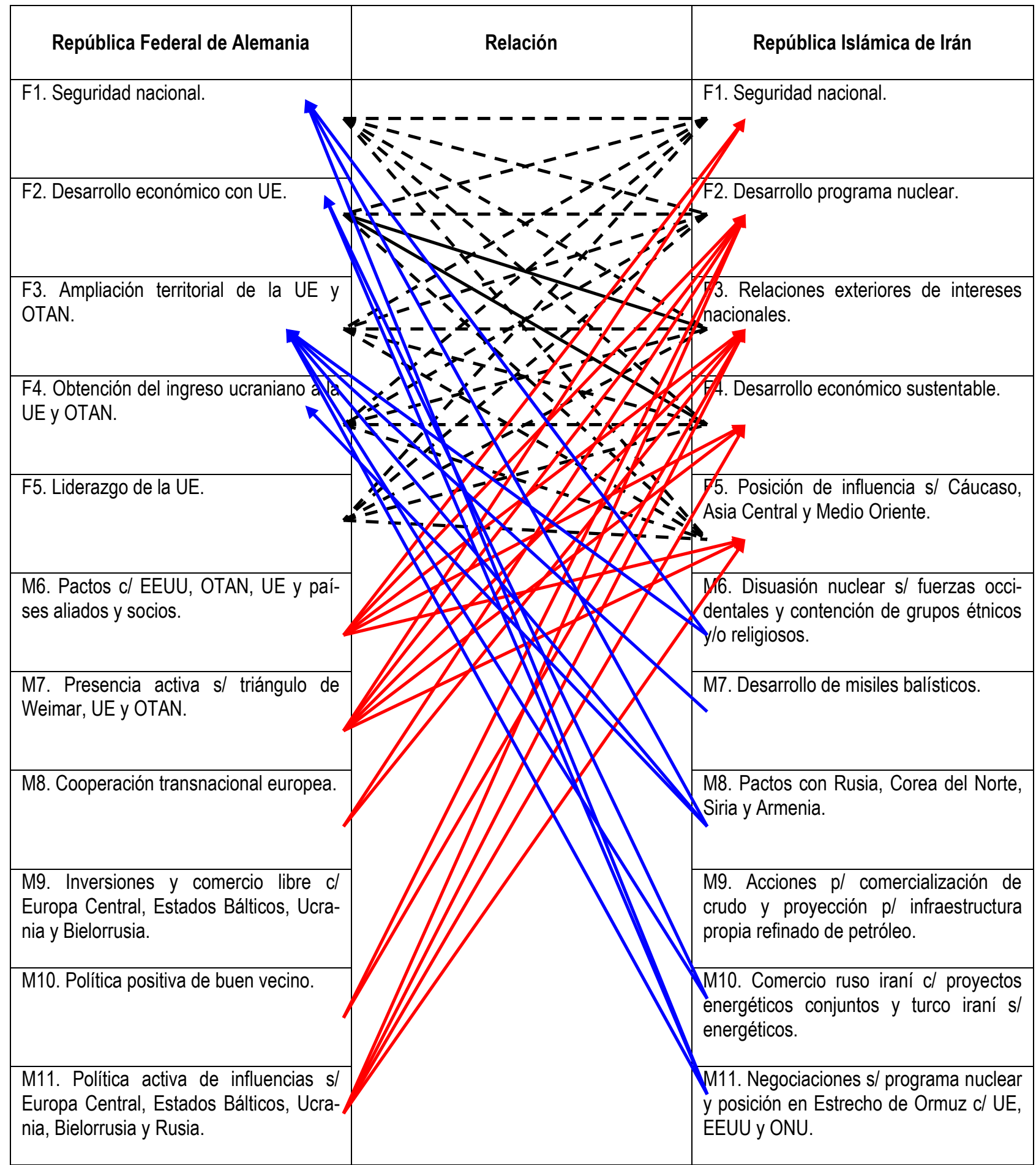

IDENTIFICACIÓN: fines con fines.

PODER: medios a fines.

FUERZA: medios de cambio a medios de cambio. Relación cuantitativa.
Cooperación

Competencia

$\mathrm{Fp} / \mathrm{Fa}$ 
Planilla 52. Relaciones de intereses República Federal de Alemania - República Popular de China

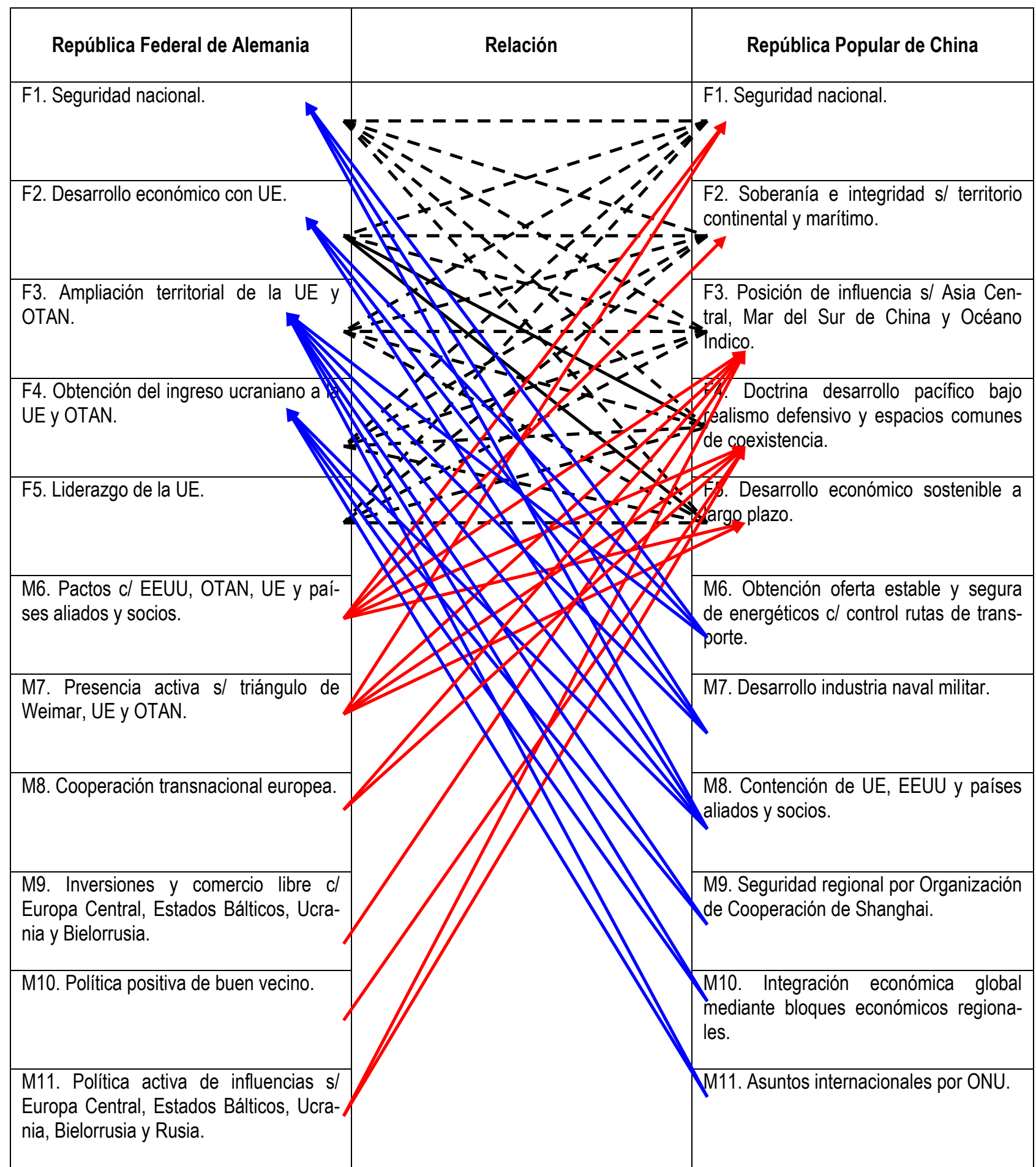

IDENTIFICACIÓN: fines con fines.

PODER: medios a fines.

FUERZA: medios de cambio a medios de cambio. Relación cuantitativa.
Cooperación

Competencia

$\mathrm{Fp} / \mathrm{Fa}$ 
Planilla 53. Relaciones de intereses República Francesa - República Islámica de Irán

\begin{tabular}{|c|c|c|}
\hline República Francesa & Relación & República Islámica de Irán \\
\hline F1. Seguridad nacional. & & F1. Seguridad Nacional. \\
\hline F2. Disuasión nuclear. & & F2. Desarrollo programa nuclear. \\
\hline F3. Pacto seguridad EEUU - UE. & & laciones exteriores de intereses \\
\hline $\begin{array}{l}\text { F4. Ampliación territorial de la UE } \\
\text { OTAN. }\end{array}$ & & Desarrollo económico sustentable. \\
\hline $\begin{array}{l}\text { F5. Liderazgo UE e influencia en } \\
\text { expansión. }\end{array}$ & & $\begin{array}{l}\text { Posición de influencia s/ Cáucaso, } \\
\text { Central y Medio Oriente. }\end{array}$ \\
\hline $\begin{array}{l}\text { M6. Presencia activa s/ triángulo de } \\
\text { Weimar, UE, OTAN, ONU y países } \\
\text { francófonos africanos. }\end{array}$ & & $\begin{array}{l}\text { uasión nuclear s/ fuerzas occi- } \\
\text { s y contención de grupos étnicos } \\
\text { iosos. }\end{array}$ \\
\hline $\begin{array}{l}\text { M7. Pactos c/ OTAN, UE y países alia- } \\
\text { dos y socios. }\end{array}$ & & M7. Desarrollo de misiles balísticos. \\
\hline $\begin{array}{l}\text { M8. Operaciones militares conjuntas con } \\
\text { RU. }\end{array}$ & & $\begin{array}{l}\text { M8. Pactos con Rusia, Corea del Norte, } \\
\text { Siria y Armenia. }\end{array}$ \\
\hline $\begin{array}{l}\text { M9. Relevancia UE en la reorganización } \\
\text { de la OTAN. }\end{array}$ & & $\begin{array}{l}\text { M9. Acciones } \mathrm{p} / \text { comercialización de } \\
\text { crudo y proyección } \mathrm{p} / \text { infraestructura } \\
\text { propia refinado de petróleo. }\end{array}$ \\
\hline $\begin{array}{l}\text { M10. Posición de influencia s/ países } \\
\text { europeos mediterráneo occidentales. }\end{array}$ & & $\begin{array}{l}\text { M10. Comercio ruso iraní c/ proyectos } \\
\text { energéticos conjuntos y turco iraní s/ } \\
\text { energéticos. }\end{array}$ \\
\hline M11. Mediación UE - Rusia. & & $\begin{array}{l}\text { M11. Negociaciones s/ programa nuclear } \\
\text { y posición en Estrecho de Ormuz c/ UE, } \\
\text { EEUU y ONU. }\end{array}$ \\
\hline
\end{tabular}

IDENTIFICACIÓN: fines con fines.

PODER: medios a fines.

FUERZA: medios de cambio a medios de cambio. Relación cuantitativa.
Cooperación

Competencia

$\mathrm{Fp} / \mathrm{Fa}$ 
Planilla 54. Relaciones de intereses República Francesa - República Popular de China

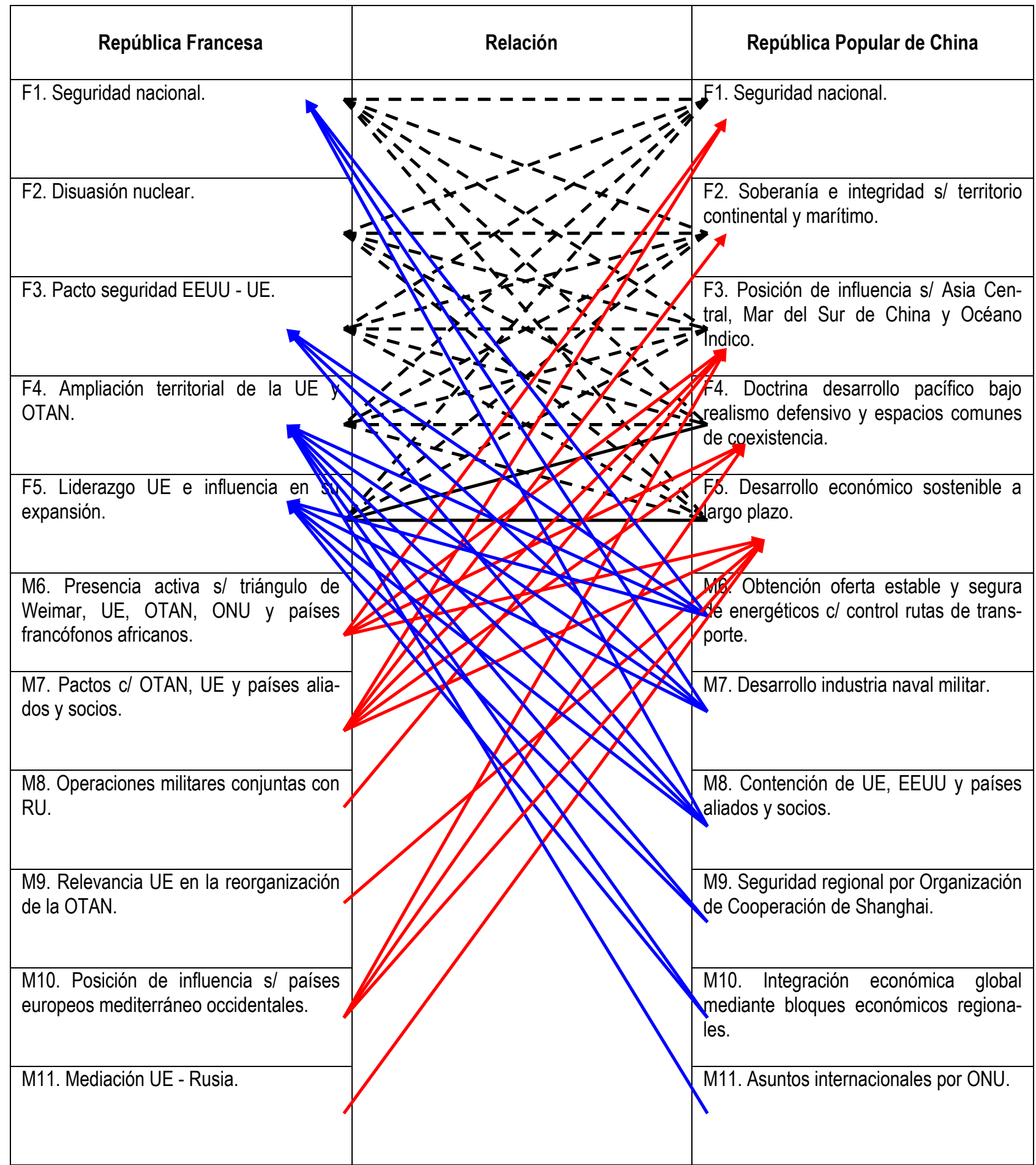

IDENTIFICACIÓN: fines con fines.

PODER: medios a fines.

FUERZA: medios de cambio a medios de cambio. Relación cuantitativa.
Cooperación Competencia

$\mathrm{Fp} / \mathrm{Fa}$ 
Planilla 55. Relaciones de intereses República Islámica de Irán - República Popular de China

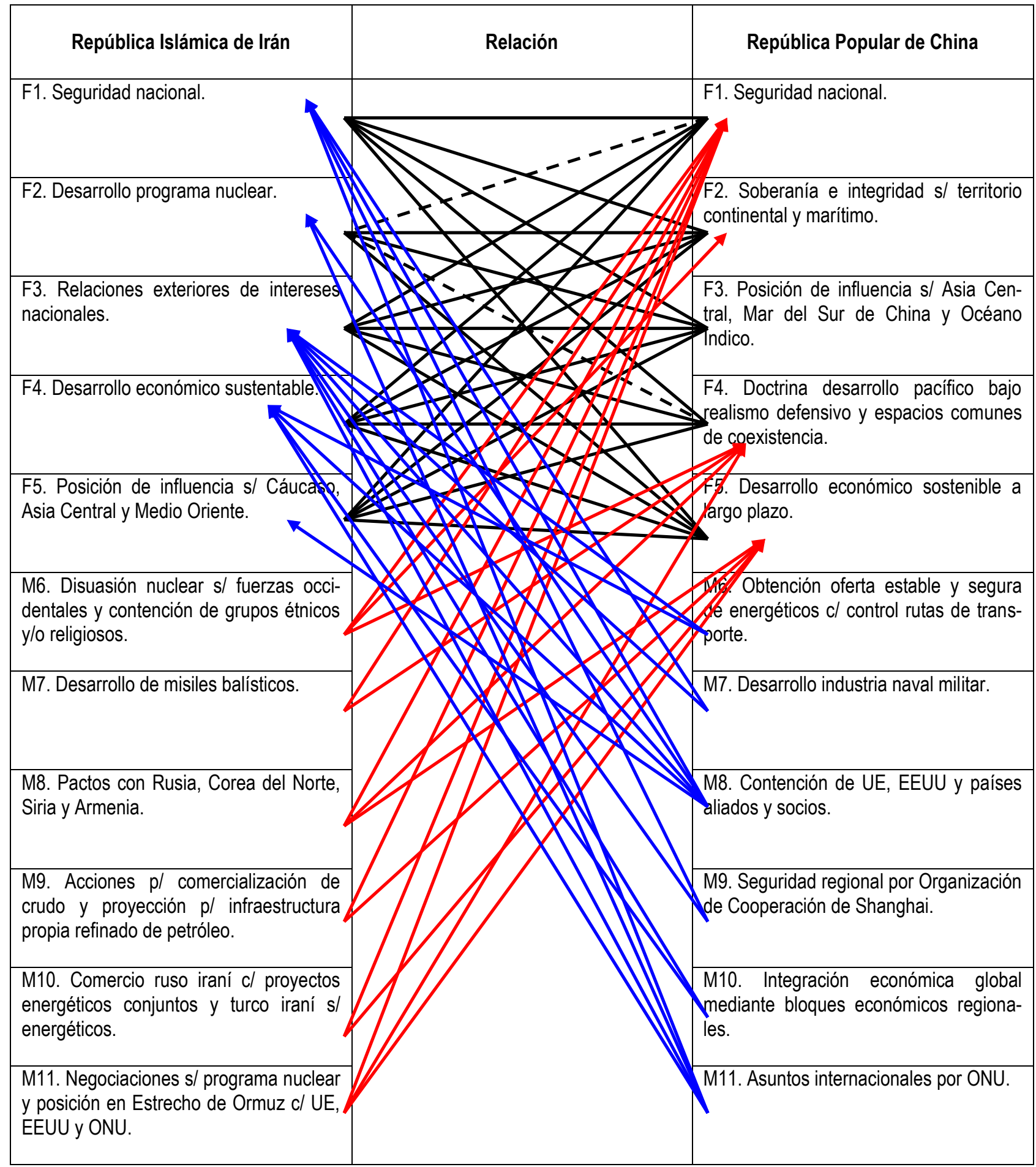

IDENTIFICACIÓN: fines con fines.

PODER: medios a fines.

FUERZA: medios de cambio a medios de cambio. Relación cuantitativa.
Cooperación Competencia

$\mathrm{Fp} / \mathrm{Fa}$ 


\subsubsection{Sociogramas de identificación, poder y fuerzas}

Además, las relaciones de identificación, poder y fuerzas, expuestas mediante los sociogramas: (i) de identificación, cuyas líneas continuas (cooperación) y punteadas (competencia) definen -de manera binaria y simétrica- el tipo de interacción entre los actores; (ii) de poder, cuyas flechas continuas exponen la dependencia de los fines de un actor de los medios de otro u otros, como relación de intereses entre actores, ya que en los ámbitos político, económico o militar, cuando los medios (factores o bases de poder ${ }^{104}$ ) de un actor afectan los fines de otro, el primero puede disuadirlo, hacerlo abandonar o asumir ciertos intereses. Entonces, aquellos que libremente controlaron sus medios tuvieron las bases de poder para ejercerlo, requiriendo de la comunicación (interacción), por cuanto sin ella, Rusia no hubiese podido orientar sus medios hacia los fines del otro; iii) de fuerzas o relación entre los medios-decambio ${ }^{105}$ de los actores involucrados, donde muestra el sometimiento de un actor a la fuerza del otro, porque las fuerzas del primero no fueron lo necesariamente fuertes para resistir. Aun así, a sabiendas de que este sociograma también permite apreciar la orientación del poder, no se realizó (1) por la gran diversidad y cantidad de medios-decambio implicados, (2) por la dificultad en obtener buena información sobre los mismos y, (3) porque si bien éste representa parte del trabajo, quedó demostrado -en opinión del suscripto- que se cumplieron los objetivos propuestos, hecho que hace irrelevante incrementar el nivel de detalle.

\section{Notación para sociogramas}

01. Federación de Rusia (protagonista, RU).

02. Ucrania (UA).

03. Estados Unidos de América (US).

04. Reino Unido de Gran Bretaña e Irlanda del Norte (GB).

05. República de Polonia (PL).

06. República de Turquía (TR).

07. República Federal de Alemania (DE).

08. República Francesa (FR).

09. República Islámica de Irán (IR).

10. República Popular de China (CN).

${ }^{104}$ El poder también depende de la posición del actor en la red de comunicaciones o interacciones del escenario.

105 Medios-de-cambio. Ingrediente material del poder con potestad de sancionar como las armas / ámbito militar, el dinero / ámbito económico y, los votos / ámbito político, de reconocimiento universal y de flexible uso para muchos propósitos. 


\section{Identificación}

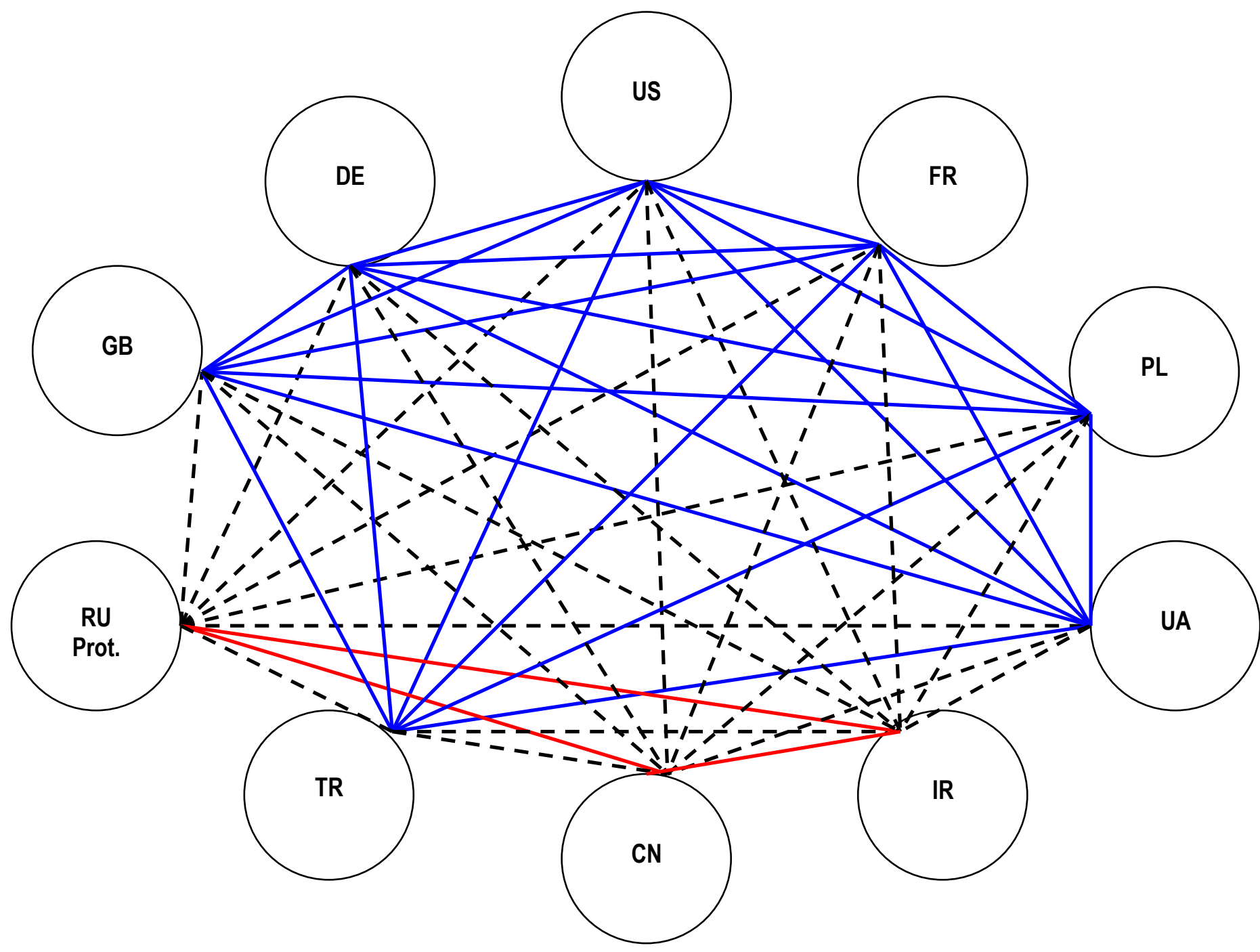




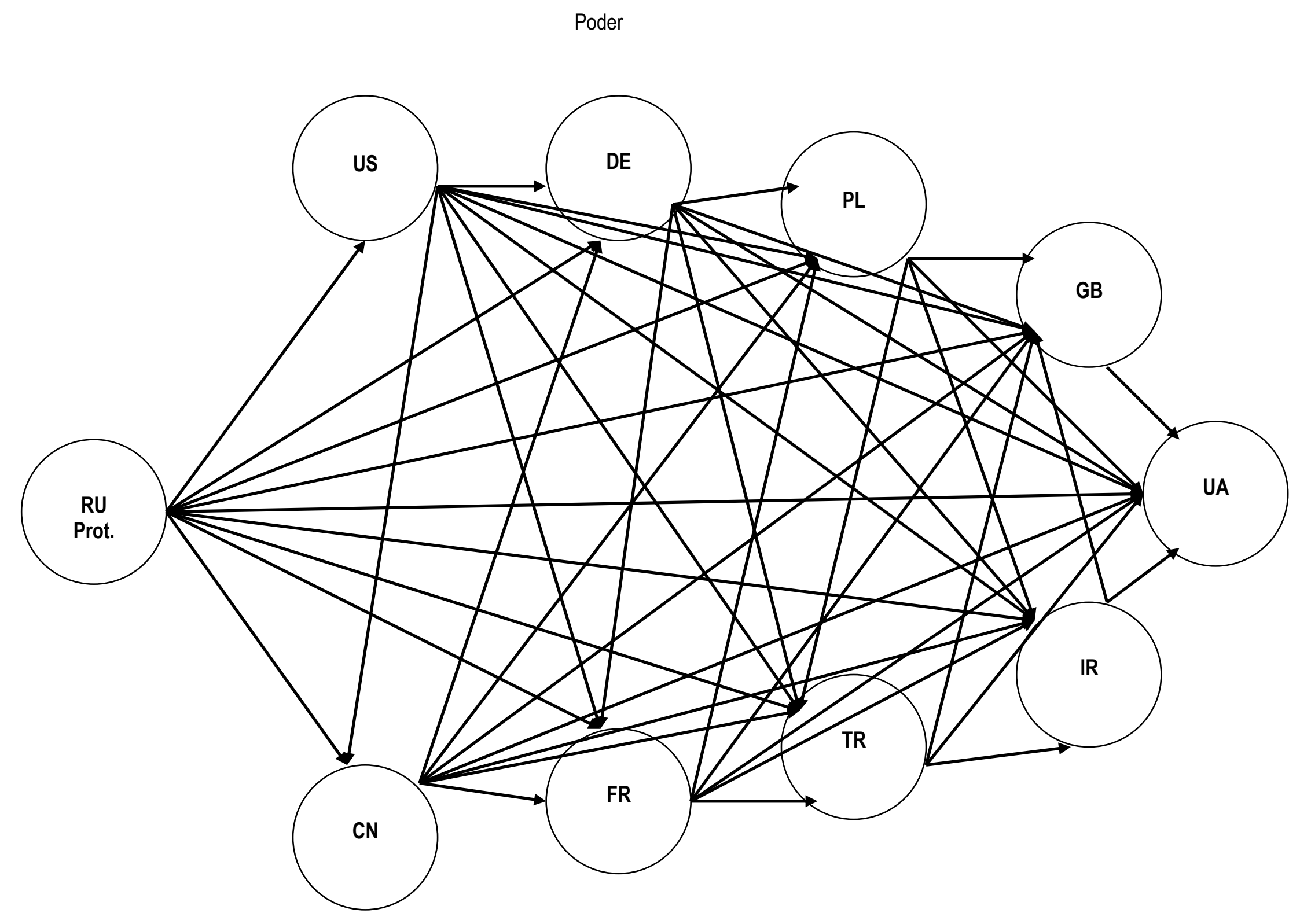


Cuadros de identificación y poder

Cuadro II. Relación de identificación entre actores

\begin{tabular}{|c|c|c|}
\hline Actor & Relación de identificación & Actor \\
\hline Federación de Rusia (protagonista) & competencia & Ucrania \\
\hline Federación de Rusia (protagonista) & competencia & Estados Unidos de América \\
\hline Federación de Rusia (protagonista) & competencia & R. U. de Gran Bretaña e Irlanda del Norte \\
\hline Federación de Rusia (protagonista) & competencia & República de Polonia \\
\hline Federación de Rusia (protagonista) & competencia & República de Turquía \\
\hline Federación de Rusia (protagonista) & competencia & República Federal de Alemania \\
\hline Federación de Rusia (protagonista) & competencia & República Francesa \\
\hline Federación de Rusia (protagonista) & cooperación & República Islámica de Irán \\
\hline Federación de Rusia (protagonista) & cooperación & República Popular de China \\
\hline Ucrania & cooperación & Estados Unidos de América \\
\hline Ucrania & cooperación & R. U. de Gran Bretaña e Irlanda del Norte \\
\hline Ucrania & cooperación & República de Polonia \\
\hline Ucrania & cooperación & República de Turquía \\
\hline Ucrania & cooperación & República Federal de Alemania \\
\hline Ucrania & cooperación & República Francesa \\
\hline Ucrania & competencia & República Islámica de Irán \\
\hline Ucrania & competencia & República Popular de China \\
\hline Estados Unidos de América & cooperación & R. U. de Gran Bretaña e Irlanda del Norte \\
\hline Estados Unidos de América & cooperación & República de Polonia \\
\hline Estados Unidos de América & cooperación & República de Turquía \\
\hline Estados Unidos de América & cooperación & República Federal de Alemania \\
\hline Estados Unidos de América & cooperación & República Francesa \\
\hline Estados Unidos de América & competencia & República Islámica de Irán \\
\hline Estados Unidos de América & competencia & República Popular de China \\
\hline R. U. de Gran Bretaña e Irlanda del Norte & cooperación & República de Polonia \\
\hline R. U. de Gran Bretaña e Irlanda del Norte & cooperación & República de Turquía \\
\hline R. U. de Gran Bretaña e Irlanda del Norte & cooperación & República Federal de Alemania \\
\hline R. U. de Gran Bretaña e Irlanda del Norte & cooperación & República Francesa \\
\hline R. U. de Gran Bretaña e Irlanda del Norte & competencia & República Islámica de Irán \\
\hline R. U. de Gran Bretaña e Irlanda del Norte & competencia & República Popular de China \\
\hline República de Polonia & cooperación & República de Turquía \\
\hline República de Polonia & cooperación & República Federal de Alemania \\
\hline República de Polonia & cooperación & República Francesa \\
\hline República de Polonia & competencia & República Islámica de Irán \\
\hline República de Polonia & competencia & República Popular de China \\
\hline República de Turquía & cooperación & República Federal de Alemania \\
\hline República de Turquía & cooperación & República Francesa \\
\hline República de Turquía & competencia & República Islámica de Irán \\
\hline República de Turquía & competencia & República Popular de China \\
\hline República Federal de Alemania & cooperación & República Francesa \\
\hline República Federal de Alemania & competencia & República Islámica de Irán \\
\hline República Federal de Alemania & competencia & República Popular de China \\
\hline República Francesa & competencia & República Islámica de Irán \\
\hline República Francesa & competencia & República Popular de China \\
\hline República Islámica de Irán & cooperación & República Popular de China \\
\hline
\end{tabular}


Cuadro III. Relación de poder entre actores

\begin{tabular}{|c|c|c|}
\hline Actor & Relación de poder & Actor \\
\hline Federación de Rusia (protagonista) & poder sobre & UA, US, GB, PL, TR, DE, FR, IR y CN. \\
\hline Estados Unidos de América & poder sobre & UA, GB, PL, TR, DE, FR, IR y CN. \\
\hline República Popular de China & poder sobre & UA, GB, PL, TR, DE, FR e IR. \\
\hline República Federal de Alemania & poder sobre & UA, GB, PL, TR, FR e IR. \\
\hline República Francesa & poder sobre & UA, GB, PL, TR e IR. \\
\hline República de Polonia & poder sobre & UA, GB, TR e IR. \\
\hline República de Turquía & poder sobre & UA, GB e IR. \\
\hline República Islámica de Irán & poder sobre & UA y GB. \\
\hline R. U. de Gran Bretaña e Irlanda del Norte & poder sobre & UA. \\
\hline Ucrania & 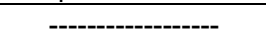 & \\
\hline
\end{tabular}

\subsubsection{Escenario}

El Teatro de Operaciones Crimea (TOC) constituyó el escenario ${ }^{106}$ o unión de los espacios donde confluyeron todos los intereses del conflicto, incluidas las reglas-de-juego, como reguladoras de las conductas de los actores.

(i) Espacios

El aludido escenario consideró los tres tipos de espacios, foros, mercados y territorios, donde se ubicaron los objetos ${ }^{107}$ vinculados a los ámbitos político, económico y/o militar. Entonces, reunidos los espacios en un solo escenario y bajo una sola conducción (unidad de mando), predominó como espacio el territorio de la República Autónoma de Crimea y el Mar Negro adyacente, correspondiendo con el ámbito militar hacia donde la Federación de Rusia -como protagonista- orientó sus recursos en pos del cumplimiento de su misión.

(a) Foros

- Comunidad de Estados Independientes (CEI).

- Consejo de Estados del Mar Báltico ${ }^{108}$.

- Fondo Monetario Internacional (FMI).

- Grupo de los Ocho (G8) 109 .

\footnotetext{
106 Escenario. En el ámbito militar se lo llama teatro de guerra o teatro de operaciones, donde se sitúan todos los medios militares y, los demás intereses vinculados a ellos.

107 Los objetos reales tienen localización espacial física, en el ámbito militar el territorio y en el económico el mercado.

108 Consejo de Estados del Mar Báltico. Países miembros: Alemania, Dinamarca, Estonia, Finlandia, Islandia, Letonia, Lituania, Noruega, Polonia, Rusia, Suecia y un representante de la Comisión Europea. Países observadores: Bielorrusia, Eslovaquia, España, Estados Unidos, Francia, Italia, Países Bajos, Reino Unido, Rumania y Ucrania.
} 
- $\quad$ Grupo de Visegrado (V4) $)^{110}$.

- Organización de Cooperación de Shanghai (OCSh).

- Organización de Naciones Unidas (ONU).

- Organización del Tratado del Atlántico Norte (OTAN).

- Organización del Tratado de Seguridad Colectiva (OTSC).

- Organización Mundial de Comercio (OMC).

- Parlamento de la Federación de Rusia111.

- Parlamento de la República Autónoma de Crimea112.

- Parlamento de la Unión Europea.

- Parlamento de Ucrania ${ }^{113}$.

- Triángulo de Weimar ${ }^{114}$.

(b) Mercados

- Comunidad de Estados Independientes (CEI).

- Comunidad Económica Euroasiática (CEEA).

- Organización de Cooperación de Shanghai (OCSh).

- Unión Europea (UE).

(c) Territorios

- República Autónoma de Crimea y Mar Negro adyacente.

\footnotetext{
109 Grupo de los Ocho. Países miembros: Alemania, Canadá, Estados Unidos, Francia, Italia, Japón, Reino Unido y Federación de Rusia, más representantes de las presidencias de la Comisión Europea y del Consejo Europeo.

110 Grupo de Visegrado. Países miembros: República Checa, Eslovaquia, Hungría y Polonia.

111 Putin firma la adhesión de Crimea a la Federación Rusia. http://www.lavozdegalicia.es/noticia/internacional/2014/03/18/putin-firma-anexion-crimea-federacion-rusa/00031395126089821135439.htm

La Duma rusa ratificará mañana el Tratado de Adhesión de Crimea.

http://noticias.lainformacion.com/disturbios-conflictos-y-guerra/conflicto-armado/la-duma-rusa-ratificara-manana-el-tratado-de-adhesion-decrimea_2jOBNAImNfyumCqSbFBUL2/

La Duma ratifica la anexión de Crimea y Sebastopol a Rusia.

http://www.elmundo.es/internacional/2014/03/20/532af1e1268e3ea30a8b4582.html

112 El Parlamento de Crimea aprueba por unanimidad su secesión de Ucrania y anexión a Rusia.

http://www.publico.es/internacional/parlamento-crimea-aprueba-unanimidad-secesion.html

Escalada en Ucrania: el Parlamento de Crimea votó la anexión a Rusia.

http://www.lanacion.com.ar/1669883-escalada-en-ucrania-el-parlamento-de-crimea-voto-la-anexion-a-rusia

El Parlamento de Crimea pide oficialmente la anexión a Rusia.

http://www.clarin.com/mundo/Parlamento-Crimea-oficialmente-anexion-Rusia_0_1103289882.html

${ }_{113}$ Nombran presidente en funciones Alexsandr Turchinov, mano derecha de Timoshenko.

http://www.20minutos.es/noticia/2066633/0/ucrania/yanukovich/timoshenko/

Ucrania disuelve la Asamblea Autonómica de Crimea a un día de celebrarse el referéndum. http://www.20minutos.es/noticia/2086013/0/ucrania/disuelve-legislativo/crimeal

114 Triángulo de Weimar. Países miembros: Alemania, Francia y Polonia.
} 
(ii) Reglas de juego

Formadas por acuerdos, leyes, roles y/o costumbres -consensuadas o impuestas- como reguladoras de las conductas de los actores, es decir, maneras legítimas de vincular intereses y establecer obligaciones y prohibiciones en el citado escenario. Modos legítimos -acordados o implícitos- de relacionar medios y fines propios y ajenos, con consecuencias sobre aquel o aquellos que los violen en sus interacciones con otros.

- Acuerdo de Establecimiento de la Comunidad de Estados Independientes ${ }^{115}$.

- Acuerdo de la Organización de Cooperación de Shanghai116.

- Acuerdos de la Organización Mundial de Comercio117.

- Acuerdo entre gobierno y oposición ucranianos del 21 de febrero del 2014118.

- Carta de la Organización del Tratado de Seguridad Colectiva ${ }^{119}$.

115 Acuerdo de Establecimiento de la Comunidad de Estados Independientes. Fundada el 08 de diciembre 1991 (fin de la URSS) en Bieloviezhe (cerca de Minsk, capital de Bielorrusia) por acuerdo entre Rusia, Bielorrusia y Ucrania. El 21 de diciembre del mismo año -en Alma-Ataonce repúblicas otrora soviéticas (Armenia, Azerbaiyán, Bielorrusia, Federación de Rusia, Kazajistán, Kirguistán, Moldavia, Tayikistán, Turkmenistán, Ucrania y Uzbekistán) adoptaron la declaración y el protocolo del Acuerdo de Establecimiento de la Comunidad de Estados Independientes, cuya Carta -del 22 de enero de 1993- establece que un Estado pertenece como miembro sólo cuando ratifica la misma. La sede oficial se situó en Minsk, siendo aceptada la CEI -el 24 de marzo de 1994- como observador en la Asamblea General de las Naciones Unidas. Dentro de la CEI, Rusia, Bielorrusia, Armenia y los países centroasiáticos, plantearon una dinámica de integración, mientras que Ucrania, Moldavia y Georgia, como el marco para un divorcio civilizado. http://www.raco.cat/index.php/RevistaCIDOB/article/download/28282/28116

${ }^{116}$ Acuerdo de la Organización de Cooperación de Shanghai. Firmado el 26 de abril de 1996 en pos de una mayor confianza militar, suscripto por Rusia, China, Kazajistán, Kirguistán y Tayikistán (los cinco de Shanghái), fijando medidas como la retirada de las FFAA a más de 100 kilómetros de sus respectivas fronteras y/o la supresión de ejercicios militares contra la otra parte. Primero fue la cooperación en el ámbito militar y, luego en junio de 2001, la OCSh y la firma de la Convención de Shanghái contra el terrorismo, el separatismo y el extremismo (las tres plagas). A éstos se les unió Uzbekistán, siendo dos de sus estructuras el Secretariado y el Centro Antiterrorista Regional, asentadas en Pekín y Taskent respectivamente. Apoyó a EEUU en Afganistán, pero cuando en julio de 2005 incomodó a Rusia y China, instaron a EEUU a retirar sus bases de Manas (Kirguistán) y K2 (Uzbekistán). Objetivos: (i) fortalecer la confianza mutua entre sus miembros, (ii) promover la colaboración política, económica, militar, comercial, científica tecnológica, cultural, educativa, energética y del transporte y, (iii) realizar esfuerzos conjuntos para la paz, la seguridad y la estabilidad en la región.

http://www.ieee.es/Galerias/fichero/docs_analisis/2011/DIEEEA18_20110rganizacionCooperacionShanghai

117 Acuerdos de la Organización Mundial de Comercio. Ente dirigido por los países que lo integran, no forma parte de la ONU y, se ocupa de las regulaciones del comercio internacional. Las fricciones comerciales se resuelven mediante el Órgano de Solución de Diferencias (OSD) reduciendo el riesgo de conflictos políticos y/o militares. Sistema multilateral de comercio con acuerdos y compromisos, negociados y firmados por la mayoría de sus Estados miembros y ratificados por sus respectivos parlamentos, que obligan a mantener políticas comerciales dentro de lo convenido. Aunque negociados y firmados por autoridades gubernamentales, ayudan a productores, consumidores, exportadores e importadores, asegurando fluidez y previsibilidad en el comercio mundial.

https://www.wto.org/spanish/thewto s/whatis s/inbrief s/inbr00 s.htm

Archivo de noticias sobre solución de diferencias. Rusia-UE.

https://www.wto.org/spanish/news_s/archive_s/dis_arc_s.htm

118 Tras la matanza de Kiev, el gobierno y la oposición en Ucrania definen un acuerdo.

http://www.lanacion.com.ar/1666105-tras-la-matanza-de-kiev-el-gobierno-y-la-oposicion-en-ucrania-definen-un-acuerdo

Ucrania: hubo acuerdo entre gobierno y oposición.

http://www.lanacion.com.ar/1666131-ucrania-hubo-acuerdo-entre-gobierno-y-oposicion

Desmentido el acuerdo entre Gobierno y oposición en Ucrania.

http://www.lavanguardia.com/internacional/20140221/54402428326/acuerdo-ucrania.html

${ }_{119}$ Carta de la Organización del Tratado de Seguridad Colectiva. Ente político militar fundado y compuesto por países de Europa y Asia Central. La Carta se firmó -el 7 de octubre de 2002- por Armenia, Bielorrusia, Rusia, Kazajistán, Kirguistán y Tayikistán, entrando en vigor en septiembre de 2003, expresando -entre otros aspectos- que sus miembros: (i) deben abstenerse del uso de la fuerza o amenaza del uso de la fuerza, (ii) no pueden integrar otras alianzas militares o grupos de Estados y, (iii) que la agresión a un país signatario constituye una agresión contra todos. El origen del OTSC deviene de la CEI (año 2000), cuando Putin propuso el cambio del Tratado de Seguridad Colectiva de la Comunidad (Tratado de Tashkent) en una nueva organización. Entonces, la OTSC -similar a la OTAN- con personal multinacional y un centro de mando móvil, constituye una alianza -compatible con la Carta de la ONU- en el sentido de que sus miembros pueden separarse cuando lo deseen. Organización para la cooperación militar y/o contra las amenazas tradicionales, que declaró el Asia Central zona libre de armas nu- 
- Carta de las Naciones Unidas ${ }^{120}$.

- Convenio constitutivo del Fondo Monetario Internacional ${ }^{121 .}$

- Memorándum sobre Garantías de Seguridad de Budapest 1994122.

- Referéndum sobre el estatus político de Crimea del 16 de marzo de $2014^{123}$.

- Tratado de Astana constitutivo de la Comunidad Económica Euroasiática124.

- Tratado sobre la no proliferación de las armas nucleares ${ }^{125}$.

- Tratado de Washington, texto jurídico fundacional de la Organización del Tratado del Atlántico Norte ${ }^{126}$.

- Versión consolidada del Tratado de la Unión Europea ${ }^{127}$.

cleares y, asumió nuevos roles contra el terrorismo y el tráfico ilícito de drogas. Afganistán y Serbia, desde 2013, tienen estatus de observadores. http://www.revistasice.com/CachePDF/ICE 857 97-110 DA42E2A571F15FFA0E88FB0F7547E955.pdf http://www.odkb.gov.ru/start/index_aengl.htm

${ }_{120}$ Carta de las Naciones Unidas. Capítulo I. Propósitos y principios. Artículos 1/2. http://www.un.org/es/charter-united-nations/index.html

${ }_{121}$ Convenio constitutivo del Fondo Monetario Internacional. Redactado por la Conferencia Monetaria y Financiera de las Naciones Unidas en Bretton Woods -Nueva Hampshire/EEUU- el 22 de julio de 1944 con representantes de 44 naciones, entrando en vigor en diciembre de 1945, con sesión inaugural en marzo de 1946 e inicio de sus operaciones en marzo de 1947. Actualmente, con sede en Washington (DC), 188 Estados miembros y 2.700 funcionarios procedentes de 147 países. Objetivos: (i) promover la cooperación monetaria internacional, (ii) facilitar la expansión del comercio mundial, (iii) promover la estabilidad en los intercambios de divisas, (iv) allanar un sistema multilateral de pagos, (v) disminuir el desequilibrio en las balanzas de pagos de sus miembros y, (vi) poner a disposición de sus socios los recursos del Fondo. http://www.imf.org/external/spanish/pubs/ft/aa/aa.pdf

122 Memorándum de Budapest sobre Garantías de Seguridad. Firmado en Budapest (Hungría)), el 5 de diciembre de 1994, dando garantías de seguridad a la adhesión de Ucrania al Tratado de No Proliferación Nuclear. El Memorándum fue suscripto por tres potencias nucleares: EEUU, Rusia y Reino Unido, luego adhirieron China y Francia. Hechos, por los que Ucrania cedió su arsenal nuclear y los vehículos para su transporte y uso, incluyendo misiles balísticos intercontinentales (ICBM) y aviones bombarderos de largo alcance. El documento incluye garantías de seguridad contra amenazas o el uso de la fuerza sobre la integridad territorial y/o la independencia política de Ucrania, Bielorrusia y Kazajistán. Según este memorándum, EEUU acusó a Rusia de no cumplir sus obligaciones para con Ucrania.. http://www.cfr.org/nonproliferation-armscontrol-and-disarmament/budapest-memorandums-security-assurances-1994/p32484

${ }_{123}$ Crimea vota en masa su futuro con Rusia.

http://www.elmundo.es/internacional/2014/03/16/53252104e2704e63108b456a.html

El 96,77 \% de los votantes de Crimea apoyan la adhesión a Rusia.

http://www.abc.es/internacional/20140316/abci-crimea-referendum-separatista-201403160709.html

Crimea declara su independencia y se incorpora a la Federación Rusa.

http://centrogilbertobosques.senado.gob.mx/docs/2103CRI.pdf

124 Tratado de Astana constitutivo de la Comunidad Económica Euroasiática. Rusia, Bielorrusia, Kazajistán y Tayikistán crean esta organización internacional con el Tratado de Astana del 10 de octubre de 2000, entrando en vigor en mayo de 2001. Tratado que expresa -en su art. 2la creación de una unión aduanera y un espacio económico común, aludiendo a tratados precedentes con voluntad de mantener sus objetivos. En principio, la CEEA nace como una organización abierta a nuevos integrantes, dado que busca la unión económica de todos los países de la CEl. El Tratado prevé el derecho de todo miembro -una vez cumplidos sus compromisos- a renunciar a su condición, como asimismo, que el Consejo Interestatal podrá expulsar o suspender a las partes que no cumplen con sus obligaciones. http://www.revistasice.com/CachePDF/ICE 857 97-110 DA42E2A571F15FFA0E88FB0F7547E955.pdf http://www.evrazes.com/docs/view/114

125 Tratado sobre la no proliferación de las armas nucleares. Apoyado en tres conceptos fundamentales: la no proliferación, el desarme y el uso pacífico de la energía nuclear. Principales artículos. Artículos I, II, III, IV, VI y X. Corea del Norte, India, Israel y Pakistán no son signatarios del tratado. Estos países dicen que el tratado genera -de hecho- un grupo de Estados con posesión legal de armas nucleares (aquellos con pruebas nucleares previas a 1967) y, otro grupo sobre los que pesa la prohibición de dicho arsenal, cuando el tratado nada dice al respecto. Tratado que se revisa cada cinco años mediante Conferencias de Revisión y, entre dos conferencias se realizan sesiones del Comité Preparatorio, a efectos de acordar recomendaciones a la próxima Conferencia de Revisión.

http://www.un.org/es/conf/npt/2005/npttreaty.html

126 Tratado de Washington. Texto jurídico fundacional de la Alianza Atlántica, suscripto el 4 de abril de 1949 en la capital norteamericana. http://elpais.com/diario/1982/05/31/espana/391644003_850215.html

127 Versión consolidada del Tratado de la Unión Europea. Título V. Capítulo 2. Sección 2. Disposiciones sobre la política común de seguridad y defensa. Artículos 42/46. http://europa.eu/pol/pdf/consolidated-treaties es.pdf 
Sanciones. Teniendo presente de que éstas no son reglas de juego (maneras legítimas de vincular intereses y establecer obligaciones y prohibiciones en el citado escenario), fueron agrupadas junto a las mismas, por cuanto -en forma de acciones sobre la Federación de Rusia- devienen de aquellas, por entender sus opuestos que -en sus interacciones- incurrió en violaciones a dichas reglas.

- Cronología de las sanciones a Rusia por la crisis en Ucrania ${ }^{128}$.

- Guerra de sanciones entre EE.UU. y Rusia por Crimea ${ }^{129}$.

- Los países más industrializados apartan a Rusia del G8 por la anexión de Crimea130.

- República Checa, Hungría, Polonia y Eslovaquia comparan la crisis de Crimea con las invasiones soviéticas ${ }^{131}$.

- Resolución de la Asamblea General de las Naciones Unidas sobre la integridad territorial de Ucrania132.

- Resolución del Parlamento Europeo, del 13 de marzo de 2014, sobre la invasión de Ucrania por Rusia133.

- "Triángulo de Weimar" para una nueva política de vecindad ${ }^{134}$.

\subsection{Evolución de la situación estratégica}

Obviamente, los sociogramas proceden de la trama actual del conflicto, reflejando el desarrollo de la situación estratégica los equilibrios de los sociogramas de identificación y poder, por cuanto la naturaleza mixta cooperativa y competitiva- de la interacción presentará nuevos desequilibrios, atento a que los actores -con cada movida- cambian el juego y, considerando que los actores tienden por lo general -en un conflicto múltiple- a formar dos coaliciones, para ubicar a Rusia y los demás actores en sus respectivos grupos, se los clasificó -según la pertinente identificación- en dos subconjuntos, de modo tal que cada vínculo de cooperación (línea continua) sitúo a ciertos actores en uno de ellos y, cada relación de competencia (línea punteada) a los actores de diferentes coaliciones.

\footnotetext{
${ }^{128}$ Cronología de las sanciones a Rusia por la crisis en Ucrania. http://mundo.sputniknews.com/mundo/20140819/161352281/Documentacin-Cronologa-de-las-sanciones-a-Rusia-por-la-crisis-en-Ucrania.html 129 Guerra de sanciones entre EE.UU. y Rusia por Crimea. http://lanacion.com.ar/1673998-guerra-de-sanciones-entre-eeuu-y-rusia-por-crimea

130 Los países más industrializados apartan a Rusia del G8 por la anexión de Crimea. http://elpais.com/m/internacional/2014/03/24/actualidad/1395646165_225453.html

131 República Checa, Hungría, Polonia y Eslovaquia comparan la crisis de Crimea con las invasiones soviéticas. http://www.europapress.es/internacional/noticia-republica-checa-hungria-polonia-eslovaquia-comparan-crisis-crimea-invasiones-sovieticas20140304231115.html

132_Resolución 68/262 de la Asamblea General de las Naciones Unidas sobre la integridad territorial de Ucrania. 27 de marzo de 2014 . Solicitó a los Estados que no tomen medidas que impliquen la interrupción parcial o total de la unidad nacional y de la integridad territorial de Ucrania, incluido cualquier intento de modificación de sus fronteras. El texto no mencionó a Rusia y fue aprobado por 100 votos a favor, 11 en contra, 58 abstenciones y 24 Estados no participaron de la votación. Asimismo, el documento indicó que el referéndum del 16 de marzo de 2014 no tiene validez ante cualquier alteración del estatuto de la República Autónoma de Crimea y/o de la ciudad de Sebastopol. Documento, que jurídicamente no aportó nada nuevo, pero con un claro mensaje para que -lo ocurrido en Crimea- no siente un precedente en el derecho internacional. http://rebelion.org/noticia.php?id=182877

133 Resolución del Parlamento Europeo, del 13 de marzo de 2014, sobre la invasión de Ucrania por Rusia. http://www.voltairenet.org/article182712.html

134 "Triángulo de Weimar" para una nueva política de vecindad.

http://m.dw.com/es/tn\%C3\%A1nqulo-de-weimar-para-una-nueva-pol\%C3\%ADtica-de-vecindad/a-17535523
} 


\subsubsection{Coaliciones ${ }^{135}$ (equilibrio de la identificación)}

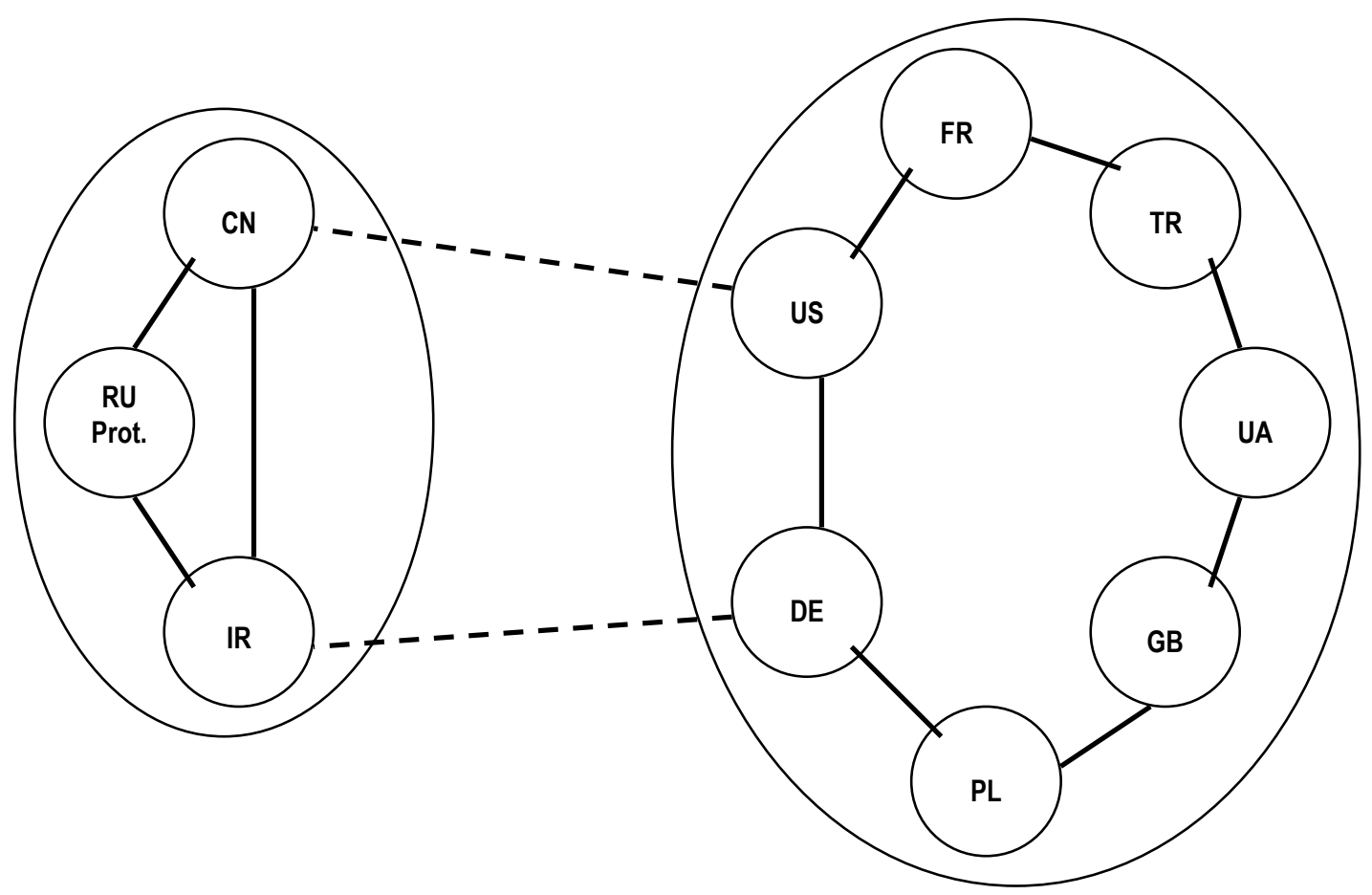

\subsubsection{Equilibrio del poder}

El poder pertinente a los actores de cada una de las coaliciones en equilibrio, está dado -en las decisiones interactivas- por la trama de relaciones, es decir, por la conectividad de la trama que fija las posibilidades de influencia y su transmisión por la cadena de poder. Entonces, la posible influencia -directa o indirecta- de Rusia y de los demás actores está en la dirección del poder y no en su magnitud, por lo que analizando el correspondiente sociograma muestra -a simple vista- el peso del poder de cada actor.

Por cierto, el sociograma en cuestión, está asociado a una matriz cuyos coeficientes otorgan una medida relativa a cada flecha de poder, de modo que sumen 1 (uno) todas las que inciden sobre cada actor, incluso la propia. Ergo, dicha matriz y sus valores relativos representan la percepción de poder -directo e indirecto- que Rusia y los demás actores pueden ejercer sobre otros (posibilidades de influencia), donde los coeficientes muestran el poder de los actores de las columnas sobre los actores de las filas.

\footnotetext{
135 Notaciones abreviadas. Federación de Rusia RU, Ucrania UA, Estados Unidos de América US, Reino Unido de Gran Bretaña e Irlanda del Norte GB, República de Polonia PL, República de Turquía TR, República Federal de Alemania DE, República Francesa FR, República Islámica de Irán IR y, República Popular de China CN.
} 
Cuadro IV. Matriz de poder

\begin{tabular}{|l|c|c|c|c|c|c|c|c|c|c|c|}
\hline IIIIIIIIIII & RU & US & CN & DE & FR & PL & TR & IR & GB & UA & Total \\
\hline RU & 1,000 & 0 & 0 & 0 & 0 & 0 & 0 & 0 & 0 & 0 & 1 \\
\hline US & 0,500 & 0,500 & 0 & 0 & 0 & 0 & 0 & 0 & 0 & 0 & 1 \\
\hline CN & 0,333 & 0,333 & 0,333 & 0 & 0 & 0 & 0 & 0 & 0 & 0 & 1 \\
\hline DE & 0,250 & 0,250 & 0,250 & 0,250 & 0 & 0 & 0 & 0 & 0 & 0 & 1 \\
\hline FR & 0,200 & 0,200 & 0,200 & 0,200 & 0,200 & 0 & 0 & 0 & 0 & 0 & 1 \\
\hline PL & 0,166 & 0,166 & 0,166 & 0,166 & 0,166 & 0,166 & 0 & 0 & 0 & 0 & 1 \\
\hline TR & 0,142 & 0,142 & 0,142 & 0,142 & 0,142 & 0,142 & 0,142 & 0 & 0 & 0 & 1 \\
\hline IR & 0,125 & 0,125 & 0,125 & 0,125 & 0,125 & 0,125 & 0,125 & 0,125 & 0 & 0 & 1 \\
\hline GB & 0,111 & 0,111 & 0,111 & 0,111 & 0,111 & 0,111 & 0,111 & 0,111 & 0,111 & 0 & 1 \\
\hline UA & 0.100 & 0,100 & 0,100 & 0,100 & 0,100 & 0,100 & 0,100 & 0,100 & 0,100 & 0,100 & 1 \\
\hline
\end{tabular}

Ahora bien, la percepción de poder -directo e indirecto- del protagonista sobre los demás actores asume un valor relativo de $1.458(1,000+0,333+0,125)$, mientras que EEUU -líder de la coalición opuesta- una cifra de 1.469 $(0,500+0,250+0,200+0,166+0,142+0,111+0,100)$, ambos indicadores dicen de que este último tiene mayores posibilidades de influencia, al tiempo que parecen ubicar a Rusia en una situación más vulnerable, pero teniendo presente la libertad-de-acción como "el poder del protagonista sobre los demás actores", que descompone el peso del poder en un aspecto activo y otro pasivo, siendo este último la vulnerabilidad ${ }^{136}$, no deja fuera la posibilidad de que EEUU tenga mayor libertad-de-acción con peligrosa vulnerabilidad. Máxime, cuando frente a un conflicto múltiple y complejo, su coalición tiene -subjetivamente- asignados mayor cantidad de miembros, circunstancias que lo sitúan ante una menor posibilidad de influencia y -consiguiente- control sobre sus aliados, además de que posee dos halcones y cinco palomas. Mientras que el protagonista, ubicado en una coalición de menor cantidad de integrantes, tiene mayor posibilidad de influencia y control sobre los mismos, sumado al hecho de que posee tres halcones y en apariencia como aliados- menos vulnerables. Entonces, simultáneamente consideradas las percepciones de poder y dependencia, como lo demuestran -a simple vista- el respectivo sociograma y su matriz asociada, llevan a presumir que -a pesar de las sumas relativas- la Federación de Rusia está en una mejor posición ante la futura evolución del conflicto.

\subsection{Evaluación de la situación estratégica}

Evaluado el conflicto en función del grado de libertad de acción (alta o baja) y de la vulnerabilidad (alta o baja) de Rusia y de los demás actores, quedó establecida la intensidad del conflicto y su riesgo de escalada. Por cierto, definido el nivel del conflicto como la opción máxima con la que intercambiaron intereses el protagonista y los otros actores, que apoyada en la identificación (cooperativa o competitiva) fue dentro de la gama de opciones ${ }^{137}$-en orden ascendente- lo que determinó el énfasis puesto en el conflicto mediante: entendimiento, preferencia, promesa,

\footnotetext{
${ }^{136}$ Vulnerabilidad. En cierta forma opuesta a la libertad-de-acción y, definida como "el poder de los demás sobre el protagonista".

137 Gama de opciones. (1) Entendimiento, (2) preferencia, (3) promesa, (4) comercio, (5) debate, (6) diversión, (7) coacción y (8) acto de fuerza, donde las cuatro primeras son cooperativas y las cuatro últimas competitivas. En el tradicional espectro o nivel del conflicto de paz, crisis y guerra, las seis primeras corresponden a la paz, la coacción a la crisis y el acto de fuerza a la guerra.
} 
comercio, debate, diversión y coacción, donde las cuatro primeras son cooperativas y las tres últimas competitivas. Obviamente, desde las opciones cooperativas a las competitivas -de menor a mayor intensidad (espectro)- creció el grado del conflicto cuando se pasó de relacionar fines a intercambiar medios.

Entonces, dichas opciones regularon la escalada para controlar el conflicto, evitando una espiral con riesgo de escalada inaceptable ${ }^{138}$, donde el concepto de escalada / desescalada está referido a la interpretación estratégica de la intensidad del conflicto, como que escalar o desescalar representa elevar o bajar el énfasis puesto en el conflicto por ascender o descender en la gama de opciones. Seguramente, la opción significó una decisión crítica para Rusia, de la que dependió su ingreso o no a una escalada en espiral, entendiendo el riesgo de escalada como aquella posibilidad de que un actor escale por sobre su opción, atento a que su saldo entre fines y medios beneficios y costos- en juego resulte mayor que el suyo, denominado también "equilibrio o riesgo crítico" y, desde una mirada opuesta, "dominancia de la escalada" -o posibilidad de una escalada acometida por un actor que el otro no puede o no quiere reciprocar- a favor de Rusia.

Cuadro V. Evaluación de la situación estratégica

\begin{tabular}{|l|l|l|c|}
\hline Libertad de acción & Alta & Nivel del conflicto & $\begin{array}{c}\text { Coacción } \\
\text { (opción competitiva) }\end{array}$ \\
\hline Vulnerabilidad & Baja & Riesgo de escalada & Alto \\
\hline
\end{tabular}

\footnotetext{
138 Escalada inaceptable. Escalada de un opuesto que el protagonista no está en actitud y/o aptitud de replicar.
} 


\section{CAPÍTULO IV}

\section{CONCLUSIONES}

Vista la misión rusa como imponer límites a las expansiones de la UE y OTAN impidiendo el ingreso de Ucrania a dichas estructuras, adherir la República Autónoma de Crimea preservando su posición estratégica sobre el mar Negro y su correspondiente proyección naval, intervenir en defensa de sus intereses nacionales y/o población rusa y/o pro-rusa amenazada, asistir económica y financieramente a Ucrania, establecer con los miembros de la CEI una mayor integración político militar y económica y, construir junto a China e Irán una contra alianza estratégica restaurando su influencia sobre las ex-repúblicas soviéticas, al tiempo que lograr la unidad euroasiática recuperando su otrora liderazgo con incidencia en los asuntos globales.

Por cierto, considerando que Rusia siempre buscó su expansión territorial adoptando una misión supranacional, determinada en términos paneslavistas, religiosos, ideológicos y geopolíticos. Así que cuando -después de la URSS- su territorio se redujo, surgieron aquellas tres opciones, los liberal atlantistas y su asociación estratégica madura con Estados Unidos a favor de un condominio global, los centristas y su extranjero próximo mediante una integración político militar y económica dominada por Moscú y, los nacional conservadores y su contra alianza euroasiática a la influencia estadounidense y europea en Eurasia. Entonces, sin una asociación estratégica madura, frente a la desconfianza de una mayor integración política, militar y económica dentro del pasado espacio soviético y, ante la cautelosa conducta china e iraní, los rusos tomaron criterios paneslavistas junto a elementos de sus políticas de prioridad en el extranjero próximo y de contra alianza euroasiática en pos de su misión.

Además, Ucrania y Crimea son para Rusia parte de su historia y esfera de influencia y, desde Sebastopol la flota rusa tiene incidencia sobre el Mediterráneo Oriental, los Balcanes y el Cercano y Medio Oriente, siendo una base que retomó importancia ante la guerra de Georgia, la problemática Libia, la piratería en el Océano Índico y en el actual conflicto sirio, de innegable valor estratégico, pudiendo afectar a muchos actores regionales y no regionales. Motivos de la actual proyección naval rusa, adhiriendo la península -de hecho y de iure- contra la política estadounidense de ampliar la UE y OTAN. Choque de intereses, que junto a cuestiones como el endeudamiento de las economías occidentales, la dependencia europea del gas y petróleo rusos y la globalización de las empresas multinacionales, conformaron servidumbres frente a Rusia, China, Irán y/o una alianza entre éstos, de hecho, la dependencia energética europea obstruyó las sanciones a Rusia.

Asimismo, presentes los tres elementos de la teoría realista, el Estado como legítimo representante y actor fundamental del sistema internacional, la soberanía estatal por sobre cualquier otra autoridad en un cierto territorio y la supervivencia como prioridad, bajo los supuestos de que no existe un nuevo orden y que la comunidad mundial 
tiene pautas diferentes a las del Estado, tenemos que la defensa soberana en procura de la supervivencia estatal implicó la regla a seguir, por cuanto el protagonista y los demás actores -tendiendo a la anarquía- defendieron sus intereses. Indudablemente, las relaciones entre Rusia, Ucrania y las de éstos con los demás actores, apoyadas en los ámbitos (ejes) político, económico y militar relacionados de diferentes modos, fijaron el orden y el régimen del sistema mediante el ámbito militar, donde predominó el poder básico y del que emanó el mismo como variable crítica. Surgiendo la racionalidad interdependiente donde el protagonista actúo acorde la acción de los demás, que afectaron su libertad de acción apoyado en la comunicación, donde Rusia afirmó con hechos -el mensaje de Vladimir Putin- de que Georgia y Ucrania son los límites a la UE y OTAN, dando a conocer sus intereses a través del contenido, autoridad y argumento de sus mensajes, los que fueron criticados -hasta cierta solución transitoria- ante la cuestión de fondo del conflicto: la pugna ruso estadounidense sobre el Asia Central.

A la sazón, el protagonismo dado a Rusia estuvo en el hecho de comprender mejor su discurso, como actor privilegiado que mediante su misión identificamos sus intereses y los pertinentes a los otros actores. Misión, que implicó el juego histórico de intereses de los conducidos, siendo el nexo entre el frente interno y externo que asumieron sus dirigentes, ante actores geoestratégicos como Estados Unidos, Alemania, Francia y China y, pivotes geopolíticos como Ucrania, Gran Bretaña, Polonia, Turquía e Irán, a sabiendas de que sólo Turquía e Irán -en la medida de sus posibilidades- pueden también constituirse en jugadores geoestratégicos. Expresando en un escenario, la racionalidad de cada actor como forma coherente de otorgar valores y preferencias a los objetos, surgiendo el conflicto cuando todos los involucrados asignaron diferentes valores a los mismos objetos, que clasificados jerárquicamente en fines o medios bajo un orden de importancia, quedaron en la trama del conflicto y, la motivación de cada actor -en su relación con los demás- por las variables determinación, aversión al riesgo y empatía, que graduadas mediante una de dos constantes (alta o baja), marcó sus conductas como competitivos halcones o cooperativos palomos. Todo lo cual, mostró que el protagonista, Estados Unidos, Turquía, Irán y China actuaron como halcones, mientras que el resto lo hizo como palomos, razones por las que Rusia -conociendo las motivaciones de aliados y opuestosacotó su incertidumbre y escaló en la gama de opciones.

La trama del conflicto constituyó una abstracción para comprender la dialéctica de voluntades y, conocer quienes cooperaron entre sí y quienes no, siendo obvio que Rusia, Irán y China -con más fines coincidentes que discrepantes- presentaron relaciones de cooperación, como asimismo entre Ucrania, EEUU y los demás actores, a la vez que existe -entre estos dos subconjuntos- una clara vinculación de competencia plasmadas en el sociograma de identificación. Mientras el sociograma de poder -con flechas continuas- expuso la dependencia de los fines de un actor de los medios de otro u otros. Ergo, el protagonista -que libremente controló sus medios- tuvo los factores de poder para ejercerlo, haciendo uso de la comunicación para orientarlos hacia los fines de su contraparte. Lo expuesto, subsumido en un escenario donde Rusia ubicó los objetos de los tres ámbitos bajo una sola conducción, prevaleciendo el territorio de la República Autónoma de Crimea y el Mar Negro adyacente (Teatro de Operaciones Crimea- 
TOC), propio del ámbito militar hacia donde dirigió sus recursos y donde confluyeron todos los intereses del conflicto, incluso las reglas-de-juego, que sus opuestos le hicieron pesar -mediante sanciones- por entender que incurrió en violaciones a las mismas.

En suma, ante los equilibrios dados y como los actores tienden -en un conflicto múltiple- a formar dos coaliciones, tenemos que Rusia, Irán y China constituyeron -según el sociograma de identificación- un subconjunto, mientras que Ucrania, Estados Unidos y los demás actores conformaron el otro. En cuanto al poder de los actores, analizando el pertinente sociograma y su matriz asociada, sus flechas de poder y valores relativos muestran la percepción de poder -directo e indirecto- que Rusia y los otros actores pueden ejercer. Ahora bien, dichos indicadores dicen que Estados Unidos tiene mayores posibilidades de influencia, mientras ubican a Rusia en una posición más vulnerable, pero como la libertad-de-acción descompone el peso del poder en un aspecto activo y otro pasivo (vulnerabilidad), ponen a Estados Unidos ante una -supuesta- mayor libertad-de-acción y peligrosa vulnerabilidad. Máxime, cuando frente a un conflicto múltiple y complejo, su coalición tiene -subjetivamente- asignados mayor cantidad de miembros, circunstancias que lo sitúan ante menores posibilidades de influencia y control sobre sus aliados, además de que compone un grupo de dos halcones y cinco palomas. A la vez que el protagonista en una coalición de menor cantidad de integrantes, tiene mayores posibilidades de influencia y control sobre los mismos, sumado al hecho de que conforma un grupo de tres halcones y en apariencia menos vulnerables. Ergo, simultáneamente consideradas las percepciones de poder y dependencia, permiten suponer que Rusia está en una mejor posición ante la futura evolución del conflicto.

Evaluado el conflicto en función del grado de libertad de acción y vulnerabilidad de los involucrados, a modo de fijar su intensidad y riesgo de escalada, que apoyado en la identificación quedó establecido su nivel en la opción máxima o coacción como elección competitiva. Obviamente, ésta significó una decisión crítica para Rusia, que tuvo en cuenta el riesgo de escalada, como aquella posibilidad de que un actor escale por sobre su opción, atento a que su saldo entre fines y medios -beneficios y costos- en juego resulte mayor que el suyo, llamado también equilibrio o riesgo crítico y, desde una visión opuesta, dominancia de la escalada o posibilidad de un ascenso dentro del espectro, que Rusia acometió y que el otro no pudo o no quiso reciprocar.

Entonces, siendo la hipótesis a contrastar: si entre el 21 de noviembre de 2013 y el 21 de marzo de 2014 inclusive, subsumida en el conflicto ruso ucraniano, el cumplimiento de la misión de la Federación de Rusia se asocia a la adhesión territorial de la República Autónoma de Crimea. De hecho, afirma al protagonista como aquel que cumplió parcialmente con su misión, puesto que en la cadena de medios a fines, el mantenimiento de su flota del Mar Negro y la base naval de Sebastopol, el incremento de su influencia política, económica y militar en la CEI, como asimismo, la construcción de una contra alianza estratégica con China e Irán y la adhesión territorial de la península de Crimea, fueron objetivos cronológicamente logrados y totalmente congruentes con la misma, para perpetuar aquel 
proyecto de expansión zarista soviético, a efectos de recuperar su anterior liderazgo con influencia en los asuntos mundiales en oposición a Estados Unidos y la UE. 


\section{BIBLIOGRAFÍA}

1. ALONSO, Rodolfo J.; FRISCHKNECHT, Federico; HERNÁNDEZ OTAÑO, Felipe; LANZARINI, Mario S. T.; MOYA LATRUBESSE, Eulogio A. 1995. Lógica, teoría y práctica de la estrategia. Escuela de Guerra Naval, Área Estrategia, Buenos Aires, Argentina, pp. 271.

2. ÁLVAREZ RUBIAL, Gregorio. 2014. Los factores de riesgo económico en la crisis de Ucrania. Documento de opinión 32/2014. Instituto Español de Estudios Estratégicos, Madrid, España, pp. 11.

3. BALLESTEROS MARTíN, Miguel Ángel. 2014. La importancia de los líderes en la crisis de Ucrania. Documento de análisis 38/2014. Instituto Español de Estudios Estratégicos, Madrid, España, pp. 10.

4. BALLESTEROS MARTíN, Miguel Ángel. 2014. Ucrania y el nuevo liderazgo geopolítico ruso (en panorama geopolítico de los conflictos 2014). Publicación aniversario. Instituto Español de Estudios Estratégicos, Madrid, España, pp. $9 / 18$.

5. BAQUÉS QUESADA, Josep. 2004. La seguridad global del siglo XXI: un análisis multifactorial. Publicado en Ejército, Madrid, España. Unidad 3, apuntes de cátedra Estrategia y Defensa Nacional, IIFA, Buenos Aires, Argentina, pp. 11.

6. BARTOLOMÉ, Mariano César. 2006. La seguridad internacional post 11-S: contenidos, debates y tendencias, $1^{\text {a }}$ edición. Instituto de Publicaciones Navales, Buenos Aires, Argentina, pp. 19/62 y 161/192.

7. BENEDICTO SOLSONA, Miguel 2013. Ángel. Nuevo equipo para afianzar la doctrina Obama en política exterior y seguridad. Documento de opinión 08/2013. Instituto Español de Estudios Estratégicos, Madrid, España, pp. 10.

8. BRZEZINSKI, Zbigniew. 1998. El gran tablero mundial. La supremacía estadounidense y sus imperativos geoestratégicos. Ediciones Paidós Ibérica S.A., Barcelona, España, pp. 11/123 y 163/211.

9. CARBALLO LEYDA, Alejandro. 2012. ¿Puede Irán cerrar el Estrecho de Ormuz? Algunas cuestiones jurídicas. Documento de opinión 14/2012. Instituto Español de Estudios Estratégicos, Madrid, España, pp. 9.

10. CALVO ALBERO, José Luis. 2012. El gran Cáucaso. Capítulo IV. El gran juego hoy. Irán, Rusia y Turquía. Cuadernos de Estrategia 156, grupo de trabajo número 05/2011. Instituto Español de Estudios Estratégicos, Madrid, España, pp. 157/169. 
11. CÁNOVAS SÁNCHEZ, Bartolomé. 2012. Irán: tecnología y psicología colectiva. Documento de opinión 96/2012. Instituto Español de Estudios Estratégicos, Madrid, España, pp. 16.

12. CARRASCO LEIVA, Daniel H. 2001. La doctrina estratégica militar norteamericana. Documento de análisis, año 16, núm. 3 y 4 . Fasoc, pp. 53/58.

13. DALLANEGRA PEDRAZA, Luis. 1998. El Orden Mundial del Siglo XXI. Capítulo I. Ediciones de la universidad, Buenos Aires, Argentina. C:IDocuments and SettingsllcarolMis documentosITIFIPolítica Internacional, Relaciones Internacionales. DALLANEGRA PEDRAZA.mht

14. DEVRIM, Deniz. 2012. El gran Cáucaso. Capítulo III. El papel de Turquía como potencia regional en el Cáucaso y el Mar Negro. Cuadernos de Estrategia 156, grupo de trabajo número 05/2011. Instituto Español de Estudios Estratégicos, Madrid, España, pp. 111/140.

15. DOMINGUEZ, Silvia; SÁNCHEZ, Enrique E.; SÁNCHEZ, Gabriel A. 2009. Guía para elaborar una tesis. $1^{\text {a }}$. Edición, Mc Graw-Hill//nteramericaca Editores, S. A. de C. V., México, D. F., pp. 105.

16. FRAGA, Rosendo. 2013. ¿Se revitaliza el nacionalismo? 07 de marzo de 2006. Unidad 3, apuntes de cátedra Estrategia y Defensa Nacional, IIFA, Buenos Aires, Argentina, pp. 3.

17. FURLAN, Luis Frenando. 2014. Crimea y la herencia del almirante Gorshkov. Documento marco 10/2014. Instituto Español de Estudios Estratégicos, Madrid, España, pp. 31.

18. GARCÍA SÁNCHEZ, Ignacio José. 2012. El informe anual al congreso norteamericano sobre el desarrollo militar de China. Documento informativo 36/2012. Instituto Español de Estudios Estratégicos, Madrid, España, pp. 9.

19. HIDALGO GARCÍA, María del Mar. 2014. El acuerdo nuclear del P3+3 e Irán y su repercusión en Oriente Medio. Documento de análisis 06/2014. Instituto Español de Estudios Estratégicos, Madrid, España, pp. 8.

20. HUICI SANCHO, Laura. 2010. Marco institucional regional y gobernanza. Revista de Economía, núm. 857, Información Comercial Española. Secretaría de Estado de Comercio, Madrid, España, pp. 97/110.

21. LABORIE IGLESIAS, Mario. 2012. Beneficios y costes de un ataque militar contra Irán. Documento informativo 61/2012. Instituto Español de Estudios Estratégicos, Madrid, España, pp. 4. 
22. REQUENA DEL RÍO, Pilar. 2014. Ucrania, en el abismo. Documento de opinión 23/2014. Instituto Español de Estudios Estratégicos, Madrid, España, pp. 14.

23. REQUENA DEL RÍO, Pilar. 2014. Crimea, la encrucijada de su historia. Documento de opinión 85 bis/2014. Instituto Español de Estudios Estratégicos, Madrid, España, pp. 14.

24. RUIZ GONZÁLEZ, Francisco José. 2011. Conflicto en el espacio postsoviético: situación actual y posible evolución futura. Boletín de información, núm. 319. Universidad de La Rioja, Logroño, La Rioja, España, pp. 18/28.

25. RUIZ GONZÁLEZ, Francisco José. 2011. La Organización de Cooperación de Shanghai en su X aniversario. Documento de análisis 018/2011. Instituto Español de Estudios Estratégicos, Madrid, España, pp. 10.

26. RUIZ GONZÁLEZ, Francisco José. 2012. El regreso de Putin al Kremlin y la futura política de seguridad de Rusia. Documento de análisis 017/2012. Instituto Español de Estudios Estratégicos, Madrid, España, pp. 19.

27. RUIZ GONZÁLEZ, Francisco José. 2014. Rusia: del divorcio con occidente a la luna de miel con China. Documento de opinión 62/2014. Instituto Español de Estudios Estratégicos, Madrid, España, pp. 20.

28. STANGANELLI, Isabel Cecilia. 2009. Turquía y las Repúblicas Centrales Asiáticas. Centro de Estudios Internacionales para el Desarrollo, Buenos Aires, Argentina, pp. 5.

29. VALLE PADILLA, Ana. 2014. La función estratégica de los recursos energéticos. Documento de opinión 51/2014. Instituto Español de Estudios Estratégicos, Madrid, España, pp. 19.

30. VILLAMIZAR LAMUS, Fernando. 2013. Comentarios sobre "Strategic Vision. America and the Crisis of Global Power" de Zbigniew Brzezinski. Revista Enfoques, Ciencia Política y Administración Pública, vol. XI, núm. 18. Universidad Central de Chile, Santiago, Chile, pp. 217/220.

31. ZHOU, Liying. 2014. Los dilemas geopolíticos para la emergencia de China en el siglo XXI. Una posible salida a la búsqueda del poder marítimo en el Mar del Sur de China y el Océano Índico a través del imaginario "String of Pearls". $4^{0}$ Simposio Electrónico Internacional Política China. Observatorio de la Política China, pp. 19.

Documentos, informes, notas y mapas

1. Análisis comparativo de la estrategia española de seguridad "una responsabilidad de todos". 2011. Documento de análisis 17/2011. Instituto Español de Estudios Estratégicos, Madrid, España, pp. 7/17. 
2. Crimea declara su independencia y se incorpora a la Federación Rusa. 2014. Nota de coyuntura. Centro de estudios internacionales "Gilberto Bosques", pp. 7.http://centrogilbertobosques.senado.gob.mx/docs/2103CRI.pdf

3. Diez años de La Comunidad de Estados Independientes (CEI). 2002. Revista CIDOB d'Afers Internacionals, num. 59. Fundación CIDOB, pp. 181/189. www.cidob.org

4. Geopolítica y estrategia. El estado del mundo. Strategic Forecasting Inc. (Stratfor Global Intelligence), Austin, Texas, Estados Unidos de América, pp. 31/37, 65/76 y 169/181.

5. La revisión estratégica de la defensa y seguridad del Reino Unido. 2010. Documento de análisis 19/2010. Instituto Español de Estudios Estratégicos, Madrid, España, pp. 11.

6. Mapa I. Península de Crimea

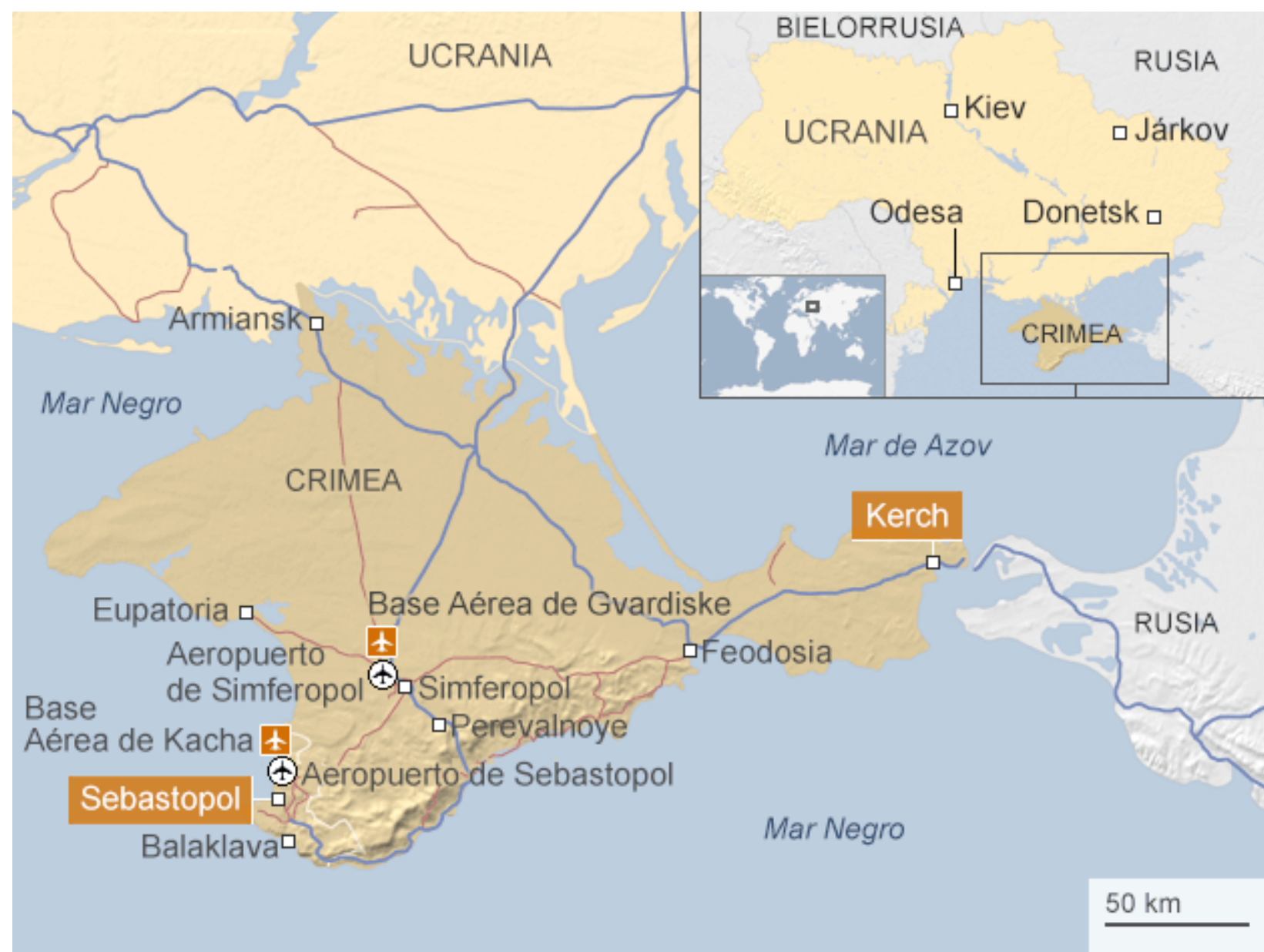

Fuente: http://www.bbc.com/mundo/noticias/2014/09/140905_ucrania_rusia_crisis_en_mapas_nc 
7. Mapa II. Gasoductos rusos orientados a la Unión Europea

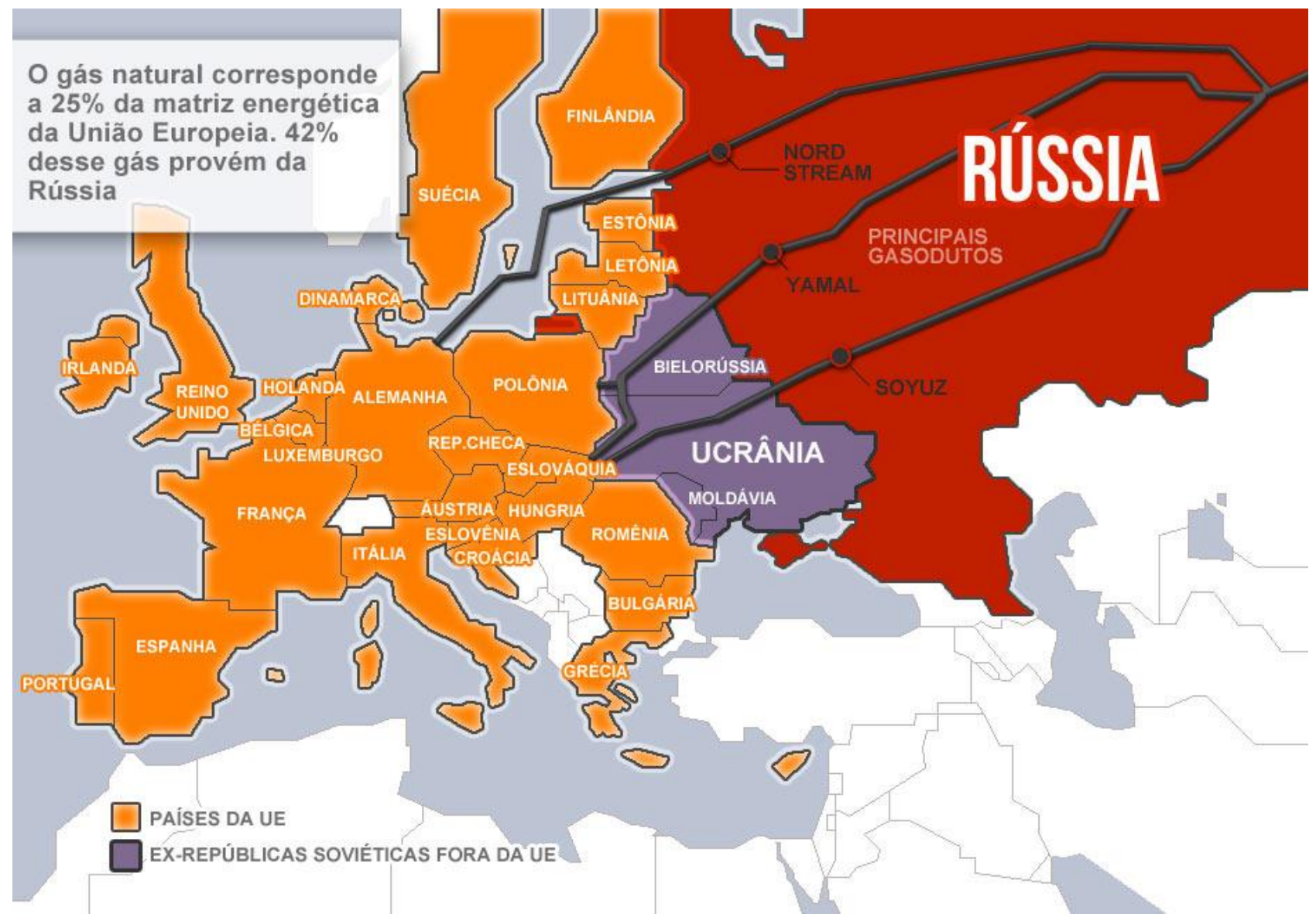

Fuente: https://www.google.com.ar/search?q=conflicto+ruso+ucraniano+2015+mapa+de+la+zona+en+conflicto\&espv=2\&biw=1024\&bih= 